\title{
AN HISTORICAL ANALYSIS OF THE BINDING EFFECT OF CLASS SUITS
}

\author{
GEOFFREY C. HAZARD, JR. $\dagger$ \\ JOHN L. GEDID I' \\ STEPHEN SOWLE TH $^{\prime}$
}

\section{INTRODUCTION}

This essay is a history of the doctrine of res judicata in class suits. It reveals that the condition of precedent on this issue was from the beginning equivocal and confused, and that it remains somewhat so today. Specifically, in the eighteenth and early nineteenth centuries, English and American decisions oscillated between saying that absent members of a class were bound by a decree and that they were not. The same pattern of equivocation persisted over the next century and into the modern era, exemplified by the decisions in Supreme Tribe of Ben-Hur v. Cauble on the one hand and Hansberry v. Lee ${ }^{2}$ on the other hand. The pattern persists in the Supreme Court's recent decisions in Cooper v. Federal Reserve Bank, ${ }^{3}$ Phillips Petroleum Co. v. Shutts, ${ }^{4}$ Amchem Products Inc. v. Windsor, ${ }^{5}$ and Matsushita Electric Industry Co. v. Epstein. ${ }^{6}$

$\uparrow$ Trustee Professor of Law, University of Pennsylvania.

t† Dean and Professor of Law, Widener University School of Law. We acknowledge with thanks the research assistance given at various points over several years by Anne $M$. Murdaugh, Edward C. Schweitzer, Jr., Stephen Smith, and William Taylor at Yale Law School, and Eric Richman and Tina W. Chao at the University of Pennsylvania Law School.

tit Associate Professor of Law, Chicago-Kent College of Law.

255 U.S. 356, 366-67 (1921) (holding that the decree of a federal court with diversity jurisdiction over a class suit is binding on absent class members who are co-citizens of the defendant).

2311 U.S. 32, 45-46 (1940) (holding that the doctrine of res judicata does not apply to absent class members whose interest were not represented by the parties to the original suit).

${ }^{3} 467$ U.S. $867,880-82$ (1984) (holding that a judgment against plaintiffs in a Title VII class action suit does not preclude individual class members from bringing individual claims of racial discrimination).

${ }^{4} 472$ U.S. 797, 823 (1985) (holding that a state's "opt out" procedure for prospective class members satisfies due process notice requirements and allows a state to assert personal jurisdiction over an absent class member who does not opt out). 
Whether a class suit decree has binding effects on the class goes to the essence of the class suit device. If the judgment is indeed conclusive on the class, the usual rules of merger and bar generally apply. If a class suit judgment is only nominally conclusive on the class members, however, its significance is minimally different from a judgment for or against one of several adversaries of a common opponent. A judgment of the latter kind may have significant effects now that the "mutuality rule" has been abolished. ${ }^{7}$ With the abolition of the mutuality rule, an absentee who is situated similarly to a prevailing litigant may be able to invoke the prevailing litigant's judgment in quite the same way a class member could do so. ${ }^{8}$ Moreover, since such a judgment may be invoked offensively against a common opponent, the judgment has powerful effects on settlement possibilities. It is also true that a victory by the common opponent against one or more of its antagonists has powerful negative effects on the settlement value of the claims of similarly situated persons. ${ }^{9}$ Thus, a judgment between one member of a group of similarly situated persons against a common opponent has significant dispute-resolving effects even without any effect of a class rule.

The key legal question for the class suit therefore has been whether, where the judgment in such a suit is adverse to the members who were actual parties, the judgment would be not merely discouraging to absentees, but preclusive against them as a matter of law-whether the rule of bar ap-

5521 U.S. 591, 117 S. Ct. 2231, 2252 (1997) (holding that a settlement in an asbestos class action case was not binding since the class lacked "the requirements of common issue predominance and adequacy of representation").

6516 U.S. 367, 374 (1996) ("[A] judgment entered in a class action, like any other judgment entered in a state judicial proceeding, is presumptively entitled to full faith and credit ....").

7 See, e.g., Parklane Hosiery Co. v. Shore, 439 U.S. 322, 326-28 (1979) (permitting the offensive use of collateral estoppel when the plaintiff was not bound by the same judgment as the defendant); Blonder-Tongue Labs., Inc. v. University of Ill. Found., 402 U.S. 313, 320-50 (1971) (holding that a determination of patent invalidity is res judicata in subsequent litigation against a different defendant); RESTATEMENT (SECOND) OF JUDGMENTS § 29 (1982).

${ }^{8}$ See Parklane Hosiery Co., 439 U.S. at 331 ("We have concluded that the preferable approach ... in the federal courts is not to preclude the use of offensive collateral estoppel, but to grant trial courts broad discretion to determine when it should be applied."); BlonderTongue Labs., 402 U.S. at 328-29 (stating that collateral estoppel is proper where a party has previously had "a full and fair opportunity to litigate" an issue); RESTATEMENT (SECOND) OF JUDGMENTS $§ 29$ (1982). But cf. RESTATEMENT (SECOND) OF JUDGMENTS § 29(3) (1982) (stating that a party that could have affected joinder in a previous action should not have the benefit of issue preclusion in a subsequent action).

${ }^{9}$ Such is the basis of early and subsequent criticism of the repudiation of the "mutuality rule," which prevents invocation of issue preclusion by third parties. See, e.g., Michael D. Green, The Inability of Offensive Collateral Estoppel to Fulfill its Promise: An Examination of Estoppel in Asbestos Litigation, 70 IowA L. REv. 141, 180-83 (1984) (discussing the impact of collateral estoppel on settlement rates). 
plies to absent class members. ${ }^{10}$ A subsidiary question is whether a judgment in favor of a class representative precludes other members of the class from seeking additional relief; that is, whether the rule of merger applies to absent class members. ${ }^{11}$

In stark legal terms, the question is whether persons who were not individually parties to a litigation will be treated as part of a set-a class-that was a party, and hence, being deemed to have participated vicariously, are now deemed to be precluded vicariously. The resolution of that question in turn involves tradeoffs between equality of outcome, which is promoted by treating the members as a group, and individuation of process, which is promoted by treating them as individuals; between the collective interest of the group and the separate interests of its members, between the procedural and strategic interests of the members and the procedural and strategic interests of the opposing party, and between the convenience of society and the interests of one or more of the parties. Combining these elements, the choice involves a calculus of the utilities and disutilities of the class suit as a mechanism of justice. This calculus is at least partially dependent on the substantive interests at stake in a particular type of class suit.

The problem can be formulated more abstractly: The law can regard any person either as a member of a group or as a legally distinct individual. ${ }^{12}$ How the law regards any particular person depends partly on the legal

${ }^{10}$ See RESTATEMENT (SECOND) OF JUDGMENTS \$§ 41(1)(e), 42 (stating that an absent class member is represented by the representative of a class of similarly situated persons and discussing the impact of collateral estoppel on settlement rates).

"See id. at $\S 42 \mathrm{cmt}$. $\mathrm{f}$ (citing cases in which a representative's collusion, inadequate conduct of litigation, or conflict of interest was a basis for refusing preclusion).

12 See also Stephen C. Yeazell, From Group Litigation to Class Action, 27 UCLA L. REV. 514, 523-35 (1980) [hereinafter Yeazell, From Group Litigation] (discussing the appearance of new group litigants as a result of industrialization in nineteenth-century England). See generally STEPHEN C. YEAZELL, FROM MEDIEVAL GROUPS TO THE MODERN CLASS ACTION (1987) [hereinafter YEAZELL, FROM MEDIEVAL GROUPS] (tracing the history of the modern class action suit); Stephen C. Yeazell, Group Litigation and Social Context: Toward a History of the Class Action, 77 CoLUM. L. REv. 866, 876 (1977) [hereinafter Yeazell, Group Litigation and Social Context] (arguing that the seventeenth-century English antecedents to the modern class were social groups such as manorial tenants whose coherence was in place before the litigation).

It has been noted recurrently that there is not necessarily a perfect homogeneity of interests among members of a group, even if all are victims of a legal wrong, and all would like some kind of legal redress. In the civil rights field, the seminal article is Derrick A. Bell, Jr., Serving Two Masters: Integration Ideals and Client Interests in School Desegregation Litigation, 85 YALE L.J. 470, 471 (1976), noting that some minority clients' "educational interests may no longer accord with the integration ideals of their attomeys." See also Leo Crowley, Note, Due Process Rights of Absentees in Title VII Class Actions-The Myth of Homogeneity of Interest, 59 B.U. L. REV. 661, 666-80 (1979) (arguing that the creation of Title VII class action suits results in inadequate representation of absentee class members with divergent interests). 
task at hand. The group most tightly bound in modern law is probably the corporation, whether business, nonprofit, or municipal. The unitary aspect of such a group is so strongly emphasized that the members of a corporation as a group are, for most purposes, treated as a legal personality that is distinct from the constituent members and exists in its own right. ${ }^{13}$ Until relatively modern times, another group of individuals treated as a unity for many legal purposes was the husband and wife. ${ }^{14}$ Partners in a business venture have been, perhaps, next closest in legal affiliation, ${ }^{15}$ followed by the members of fully organized, unincorporated associations. ${ }^{16}$

At the other end of this spectrum, the group most loosely bound is a set of persons suffering or contributing to common injury, who, in general, are permitted, but not required, to act together in joinder as plaintiffs or when joined as defendants. ${ }^{17}$ Such a set of persons may form a coalition for pursuit of their common legal interests, but the coalition is usually weak and unstable. Thus, under present procedural doctrine, the parties joined under permissive joinder are on their own for most purposes; for example, a procedural initiative taken by one is generally not attributable to the other. ${ }^{18}$

${ }^{13}$ See RESTATEMENT (SECOND) OF JUDGMENTS $\$ 59$ (1982) ("Except as stated in this Section, a judgment in an action to which a corporation is a party has no preclusive effects on a person who is an officer, director, stockholder, or member of a non-stock corporation ...."); see also Harold J. Laski, The Personality of Associations, 29 HARV. L. REV. 404, 408-15 (1916) (providing instances of courts treating corporations as individuals).

${ }^{14}$ See, e.g., WOMEN INTO WIVES: THE LEGAL AND ECONOMIC IMPACT OF MARRIAGE 84 (Jane Roberts Chapman \& Margaret Gates eds., 1977) ("[T] he tax code reinforces the traditional family model-including the dependent wife-by defining her as a family member ....”).

${ }^{15}$ See Leh v. General Petroleum Corp., 165 F. Supp. 933, 937 (S.D. Cal. 1958) (holding that one partner of a dissolved partnership may bring a suit in the partnership's name in federal court); RESTATEMENT (SECOND) OF JUDGMENTS $\S 60 \mathrm{cmt}$. a ("At common law, a partnership was treated as an aggregation of individuals and not as a jural entity distinct from its members.").

${ }^{16}$ See FED. R. CIV. P. 23(2) (providing for class actions by members of unincorporated associations); RESTATEMENT (SECOND) OF JUDGMENTS $\$ 61 \mathrm{cmt}$. a (“At common law an unincorporated association was treated as an aggregate of individuals."); Developments in the Law-Judicial Control of Actions of Private Associations, 76 HARV. L. REV. 983, 1080-81 (1963) (" $[$ S]uing personally all the members of a large association is unworkable; thus jurisdictions normally allow suit against the association in its own name or against the membership at large by means of class action or permit both techniques.").

${ }^{17}$ See FED. R. CIV. P. 20(a) (providing that persons may join as plaintiffs or be joined as defendants in one action).

${ }^{18}$ See, e.g., Poston v. Ragan, 187 S.E.2d 503, 505 (N.C. Ct. App. 1972) (holding that a party who does not file an appeal properly may not appeal from order of judge dismissing an appeal perfected by a co-party); Wolfe v. East Tex. Seed Co., 583 S.W.2d 481, 482 (Tex. Civ. App. 1979) (holding that a party may not avail himself of an objection on appeal that was made by his co-defendant at trial). 
Neither of these polar types, the individual and the group, comes in legally pure form. Those associated in a corporate undertaking, for example, have divergent interests as well as common ones, so their legal bonds are contingent, not absolute. These divergences of interest and contingencies of affiliation in the "corporate connection" are the subject of a whole jurisprudence known as corporation law. ${ }^{19}$ Similar divergences and contingencies are found in the law of partnerships and associations. ${ }^{20}$ On the other hand, persons associated merely by the fact of their common victimization have some legal connections among themselves, and accordingly may be treated as a group for some purposes. One example, already noted, is their being made the beneficiaries of issue preclusion under the modern formulation of res judicata. ${ }^{21}$ Another legal connection from mere common victimization is that the victims may be limited to proportionate recovery where only a limited fund is available to satisfy their claims. ${ }^{22}$

Bringing these variations to mind warns that it is impossible to formulate an analytically unambiguous legal definition of a "group" or "class." This means that in formulating and administering a rule of res judicata that governs class suits there is unavoidable ambiguity in the predicate definition: What, exactly, is a "class" for this purpose? This question, in turn, suggests that it is also impossible to formulate a completely neat solution to the problem of res juidicata in class suits, however tight or loose the legal bonds. within the class.

Notwithstanding these complexities, the basic choice in the rule of res judicata in class suits has been between the alternative of treating the individuals as a more or less tightly knit association acting through agents and that of treating them as individuals who ean act only for themselves. Historically, the resolution of this choice has been cast in terms of the definition

19 See generally PHILLIP I. BLUMBERG, THE LAW OF CORPORATE GROUPS: PROCEDURAL LAW 1 (1983) (discussing the "collapse of the concept of entity," which "viewed each corporation as a separate legal entity, with separate rights and obligations"); ROBERT CHARLES CLARK, CORPORATE LAW 30 (1986) (noting that corporations have "relationships" with "a number of participants or affected persons").

${ }^{20}$ See Harold GILl ReuschleIN \& William A. GREgory, The LAW OF AgENCY AND PARTNERSHIP 269 (2d ed. 1990) ("[E]ach partner is not necessarily the agent of each of his co-partners but rather of the partnership itself."). See, e.g., Yablonski v. United Mine Workers, 448 F.2d 1175, 1181-82 (D.C. Cir. 1971) (disqualifying a union's counsel from representing both the union and the union's president where there was a potential for conflict of interest between the union and its officers).

${ }^{21}$ See case cited supra note 2 and accompanying text.

22 See FED. R. CIV. P. 22 (discussing interpleader of claimants to a limited fund); FED. R. CIV. P. 23(b)(1)(B) (discussing class suits that may prevent absent members from being able to protect their interest). More generally, of course, a bankruptcy judgment imposes proportionate equality of legal position on persons whose only common bond may be that of having a common debtor. See also discussion infra Part II.B (examining class suit bills by creditors). 
of what constitutes a class. Hence, the definition of the class has been the key controversy. ${ }^{23}$

The definition of a class in a lawsuit can be specified from two different chronological points in the course of the lawsuit. One is a prospective definition adopted in connection with framing the suit at the outset. Such a definition specifies who is a party, or deemed by representation to be a party, in the instant case. The other chronological point is retrospective, specifying who was a party in the case formerly adjudicated. A prospective definition is employed in framing the action and may serve to anticipate who will be precluded by the adjudication; a retrospective definition is employed in applying the rules of res judicata and determines whether the prior forecast will actually be fulfilled. In the language of economics, the difference of perspective is that between ex-ante and ex-post.

Considerations of legal consistency and protection of party expectations require that the two definitions coincide. Of course, these considerations are not preemptory. Where numerous persons are commonly involved in a legal controversy, it could be said prospectively that the suit will bind all of them, including absentees, but then be held retrospectively that the absentees actually are not bound. (It would also be possible to say prospectively that they are. Surprise!) ${ }^{24}$ There is, however, a serious shortcoming in such inconsistency. Very simply put, if, in the administration of justice, courts take inconsistent positions ex-ante and ex-post, then party expectations are rendered uncertain. Serious unfairness can result when party expectations about the effect of the suit are uncertain.

As we shall see, over the course of history, the courts have been quite inconsistent in their position on res judicata in class suits. Notwithstanding these inconsistencies, the courts have seemed to think they were dealing with two temporal aspects of a single problem and therefore have employed a single definition both ex-ante and ex-post. The history of the class suit nevertheless demonstrates that the courts have great difficulty actually maintaining a consistent position concerning res judicata in cases where res judicata effects have practical significance.

In formulating a coherent and consistent position as to whether an absentee class member is bound by a class suit judgment, courts have relied on

${ }^{23}$ See generally Yeazell, Group Litigation and Social Context, supra note 12, and Yeazell, From Group Litigation, supra note 12, for a discussion of the history and changes in the nature of litigation groups.

${ }^{24}$ See, e.g., Lee v. Hansberry, 24 N.E.2d 37, 40 (IIl. 1939) (holding that the doctrine of res judicata extends not only to matters actually determined in the prior suit, but that it also applies to all grants of recovery and defense involved which might have been raised), rev'd 311 U.S. 32 (1940). 
two basic concepts. One is that of identity of interest among the class members. If the members of the class have a relatively strong identity of interest, then courts will be on safe ground in treating a member of the defined class, or a small group of members, as a legal representative of the whole group, and, on that basis, binding the group to the judgment. This concept is formulated in various ways: that there is a "community of interest" of the members of the group, ${ }^{25}$ that the claims of the representatives are "typical of [those] of the claims ... of the class," terests of the class "predominate over any questions affecting only individual members., 27

The other concept of binding effect is that of adequate representation. ${ }^{28}$ If the interests of the class are presented with reasonable competence and vigor, then courts will be on safe ground in treating members of the class as bound even if they did not actually participate in the litigation. This concept is also formulated in various ways, notably as whether the representatives "fairly and adequately protect the interests of the class"29 or "prosecute or defend the action with due diligence and reasonable prudence.

25 See Weaver v. Pasadena Toumament of Roses, 198 P.2d 514, 517 (Cal. 1948) (holding that "there must be a well-defined 'community of interest' in the questions of law and fact involved as affecting the parties to be represented" (citation omitted)).

${ }^{26}$ FED. R. CIV. P. 23(a)(3).

${ }^{27}$ FED. R. CIV. P. 23(b)(3).

${ }^{28}$ See FED. R. CrV. P. 23(a)(4) (stating the relationship between adequate representation and the binding effects of class suits). The differences between these concepts of representation have frequently been the subject of scholarly commentary. See, e.g., YEAZELL, FROM MEDIEVAL GROUPS, supra note 12, at 145-47 (1987) (stating that requiring "individual consent" for persons to be joined in group litigation during the seventeenth century may indicate that "the court was less prepared to accept the word of the representatives that their cause was that of the group"); George M. Strickler, Jr., Protecting the Class: The Search for the Adequate Representative in Class Action Litigation, 34 DEPAUL L. REV. 73, 74-84 (1984) (providing a historical overview of the adequacy of representation).

In more recent years, attention has shifted to the adequacy of counsel representing the class, in terms of experience, vigor, imagination, and financial resources. See, e.g., Dolgow v. Anderson, 43 F.R.D. 472, 496 (E.D.N.Y. 1968) (stating that although counsel representing the class is presumed to be competent, this presumption is not irrefutable and the court is entitled to examine evidence to the contrary), rev'd on other grounds, 438 F.2d 825 (2d Cir. 1970); Note, Collateral Attack on the Binding Effect of Class Action Judgments, 87 HARV. L. REV. 589,603 (1974) (proposing that counsel's performance is a factor which must be taken into consideration before binding absent class members to a judgment). The adequacy of counsel appears to be regarded as an additional consideration in assessing adequacy of representation, and not as a substitute for "adequacy" predicated on either "typicality" or the potency of the class representatives themselves.

29 RESTATEMENT (SECOND) OF JUDGMENTS $§ 42(d)$ (1982) (stating that discontinuity of interests between the class and counsel would not bind the judgment on the class); see also Geoffrey C. Hazard, Jr., The Settlement Black Box, 75 B.U. L. REV. 1257, 1260 (1995) (stating that settlements must be fair to the parties involved).

${ }^{30}$ RESTATEMENT (SECOND) OF JUDGMENTS $§ 42(1)$ (e) (1982). 
These two concepts are not mutually exclusive in application. A group can be regarded as "adequately represented" because the interests of the representative so clearly coincide with those of the absent members that there is a compelling inference that the representative did a reasonable job of conducting the litigation. This inference serves as the basis for the link between the concept of relative homogeneity of the interests of the class members and the imposition of res judicata on the basis of the outcome achieved by the representative. Yet, it is also clear that identity of interest among class members does not guarantee adequacy of representation.

Identity of interest without adequacy of representation is epitomized in the problem of a "sellout" by the representative. ${ }^{31}$ Although the members of the class may all have been in one boat in the transaction that is the subject of the suit, their interests can thereafter divide if their common opponent is willing to pay off some but not all of them.

There can also be adequacy of representation without identity of interest. The law, for example, is well settled that a trustee's litigation concerning the trust binds the beneficiaries even though the trustee and the beneficiary by legal definition do not share the same legal interests. ${ }^{32}$ In the case of such fiduciary representation, adequacy of representation is achieved by controls other than by the criterion of identity of interest. ${ }^{33}$

${ }^{31}$ See, e.g., Saylor v. Lindsley, 456 F.2d 896, 900 (2d Cir. 1972) (finding that representative counsel, although sharing a similar interest in a class action suit, failed to adequately represent the class by settling the suit despite the plaintiff's objection to the proposed settlement); John C. Coffee, Understanding the Plaintiff's Attorney: The Implications of Economic Theory for Private Enforcement of Law Through Class and Derivative Actions, 86 ColuM. L. REV. 669, 684-90 (1986) (illustrating the divergence of interests and economic incentives between counsel and members of the class suit).

${ }^{32}$ See Mullane v. Central Hanover Bank \& Trust Co., 339 U.S. 306, 311 (1950) (holding that since a trustee's action to close a trust will have a binding effect on all parties involved, the trustee must undertake appropriate notification procedures to notify all beneficiaries); RESTATEMENT (SECOND) OF JUDGMENTS $§ 41$ (1982) ("A person is represented by a party who is: (a) [t] he trustee of an estate or interest of which the person is a beneficiary."). See also United States v. Old Settlers, 148 U.S. 427, 480 (1892), discussed in Strickler, supra note 28 , at 79-80, in which the Court sustained a judgment where the representation of members of an Indian tribe was through government-appointed commissioners who were not members of the tribe. It is safe to say that representation so constituted would not pass muster today, if indeed it could get into the courthouse in the first instance.

${ }^{33}$ The controls are in the appointment process and in the possibility of legal review of the trustee's performance. A trustee of a privately constituted trust ordinarily is appointed by the settlor, who is assumed to have knowledge of the reliability of the designated trustee. A trustee designated by public authority must provide credentials that pass muster with the appointing authority and usually also with judicial authority. Both kinds of trustees are governed by the exacting legal standards imposed on fiduciaries and are subject to accounting and surcharge proceedings. See RESTATEMENT (SECOND) OF JUDGMENTS § 41(1)(a) (1982); RESTATEMENT (SECOND) OF TRUSTS $\$ \S 170-85$. Both kinds of trustees were involved in Mullane, 339 U.S. at 309,310 . In that case, the Central Hanover Bank had been designated as 
We think that neither of these concepts, alone or together, fully engages the problem of determining whether binding effect should be given to a class suit judgment. Our historical study of the precedents reveals that courts have never unequivocally committed themselves to a set of ex-ante procedures that will assure ex-post that the judgment will bind the members of the class in the same way as if the class members had been individually made parties. This historical record, together with critical reflection on the problems involved, convinces us (and, we hope, others) that a robust formula of class suit "bindingness" is a chimera-an alluring but unattainable goal. Concluding that class suit res judicata is a chimera contradicts a great deal of present wisdom about class suits and repudiates a position one of us has espoused previously. ${ }^{34}$ This sad conclusion, in turn, leads us to suggest the need for reconsideration of the procedural rules dealing with situations involving "numerous" persons who ought to be bound by a class suit judgment, and some kind of "one way" class suit for other situations.

We do not have a formulation for these rules. Rather, this study is a preface to formulating such rules. Its purpose is to provide an informed historical perspective of the difficulties in giving binding effect to a class suit judgment. To that extent, our analysis is a mere scholarly endeavor. There are, however, more pragmatic purposes as well.

We think our study shows that there is no firmly established doctrine concerning the attributes of a class suit that would make such a suit binding on absentee members. The verdict of the unquiescent years is, on the contrary, equivocal. It follows that the task of formulating proper doctrine in the matter requires thoughtful analysis in the present, rather than reliance on what has been said heretofore. We think our study also shows that the class suit device has had real utility in dealing with emerging legal problems in the course of our history: multiple creditors seeking redress from a debtor's limited assets, citizen suits against allegedly ill-advised public ventures, disputes within large organizations where the organization's leadership no longer provides proper leadership, civil rights controversies, and mass torts.

trustee by the private settlors; the guardian ad litem for the absentee beneficiaries was appointed by the court charged with reviewing the Bank's accounting.

${ }^{34}$ See DAVID W. LOUISELl \& GEOFFrey C. HAZARD, JR., Pleading AND PROCEDURE: STATE AND FEDERAL 680 (4th ed. 1979) ("In the class suit, on the other hand, those represented ordinarily have neither of right nor in fact an advance opportunity to challenge the qualifications of those who undertake to speak on their behalf."). Our analysis does not address other important procedural problems that attend class suits, particularly those in the federal court. These include the definition of citizenship for diversity jurisdiction, the calculation of the amount in controversy, the problem of personal jurisdiction over the class members, venue, and others. For a thoughtful review of many of these problems, see Diane Wood Hutchinson, Class Actions: Joinder or Representational Device?, 1983 SUP. CT. REV. 459. 
Indeed, all cases in which resort is made to a class suit are in some sense a kind of mass tort. Our society is increasingly and inevitably characterized by "mass" phenomena, including mass legal wrongs. Simply put, there are many of us who are "similarly situated" in any given social conflict that evolves into a legal conflict. There can be no sensible expectation that "the legislature"-whether Congress or its state counterparts-will adequately and comprehensively deal with these legal problems. The legislature, of course, can create new mechanisms, such as administrative regulation, to deal with recurrent types of wrongdoing that affect large numbers of people. It is, however, a political fact that legislatures respond to a legal problem only after the problem has achieved sufficient visibility to get a place on the legislative agenda. Even then, legislative response will be slow in coming because of uncertainty and controversy over appropriate solutions. In the meantime, the courts must respond somehow to the aggrieved claimants.

Accordingly, the hope that we could somehow abolish class suits and return to individualized justice is merely wishful thinking. However, sober thinking requires reconsideration of how to structure the mechanism properly. We hope this study provides illumination in that task.

\section{THE ENGLISH ANTECEDENTS OF THE CLASS SUIT}

\section{A. The Necessary Parties Rule}

The origins of the class action doctrine are intertwined with problems presented by the Necessary Parties Rule in English Chancery practice in the seventeenth and eighteenth centuries. The Necessary Parties Rule required that any person with an interest in the object of a suit be joined as a party. ${ }^{35}$ Several reasons were advanced for the rule: complete justice can only be

35 See, e.g., Knight v. Knight, 3 P. Wms. 331, 334, 24 Eng. Rep. 1088, 1089 (Ch. 1733) (holding that when an action in equity is brought against the heir of an estate, the executor must be made a party); Dunstall v. Rabett, Rep. T. Finch 242, 243, 23 Eng. Rep. 133, 134 (Ch. 1675) (stating that in an action to recover inheritance from an estate, failure to include other devisees will be grounds for granting a demurrer); Atwood v. Hawkins, Rep. T. Finch $113,113,23$ Eng. Rep. 62, 62 (Ch. 1673) (reasoning that in order to avoid future suits, failure to include other devisees in an action to recover from inheritance will result in dismissal); Weston v. Keighley, Rep. T. Finch 82, 82, 23 Eng. Rep. 44, 44 (Ch. 1673) (holding that in an action to recover from joint tenancy, a co-tenant must be included as a party); cf. John W. Reed, Compulsory Joinder of Parties in Civil Actions, 55 MICH. L. REv. 327, 340-74 (1957) (detailing the application of the compulsory joinder rule in various contexts). See generally Geoffrey C. Hazard, Jr., Indispensable Party: The Historical Origin of a Procedural Phantom, 61 COLUM. L. REV. 1254, 1255-89 (1961) (tracing the origins and histories of both the Necessary and Indispensable Party Rules). 
done by determining the rights of all parties connected with the subject of the suit or the relief to be granted; ${ }^{36}$ multiplicity of suits should be prevented; ${ }^{37}$ and, assurance should be provided that those persons before the court could safely execute the decree. ${ }^{38}$ This last justification for the Necessary Parties Rule arose from the fact that nonparties were held not to be bound by a decree made in their absence. ${ }^{39}$

There were, however, situations in which it was impossible or impractical to join all "necessary" parties. Courts therefore formulated exceptions to the Necessary Parties Rule. ${ }^{40}$ For example, where one of several coexecutors was out of the jurisdiction, a legatee could maintain a bill against the remaining executors; ${ }^{41}$ or, where a joint obligor ${ }^{42}$ or partner $^{43}$ was out of the jurisdiction or bankrupt, ${ }^{44}$ a creditor could nevertheless proceed against

${ }^{36}$ See Knight, 3 P. Wms. at 334, 24 Eng. Rep. at 1089 ("[T] he court of equity in all cases delights to do complete justice, and not by halves.").

${ }^{37}$ See Plunket v. Penson, 2 Atk. 51, 51, 26 Eng. Rep. 428, 429 (Ch. 1740) (holding that "[i]n bills of discovery ... you should make every person a party who is necessarily to be made so, that you may not multiply suits improperly").

${ }^{38}$ See Thompson v. Baskervill, 3 Ch. Rep. 215, 215, 21 Eng. Rep. 770, 770 (Ch. 1688) (holding that the original mortgagor must be made a party in the second mortgagee's action to set aside the first mortgage).

${ }^{39}$ See Poore v. Clark, 2 Atk. 515, 516, 26 Eng. Rep. 710, 710 (Ch. 1742) (ruling that in a bill to remove a house brought against the lord of the manor and an occupant, the other nonparty tenants of the manor were not bound); Natchbolt v. Porter, 2 Vern. 112, 114, 23 Eng. Rep. 682, 682 (Ch. 1689) (holding that a non-party assignee cannot be bound to indemnify assignor); Woodcock v. Mayne, 73 SELD. SOC'Y 314, 314 (Ch. 1676) (holding that a mortgagor must be party to a junior encumbrancer's bill against a senior mortgagee); Carpenter v. Stallard, 73 SELD. SOC'Y 109, 109 (Ch. 1674) (stating that a senior mortgagee should not be bound by a junior mortgagee's suit against the mortgagor); see also Fell v. Brown, 2 Bro. C.C. 275, 279, 29 Eng. Rep. 151, 153 (Ch. 1787) (stating that in a case of redemption of a second mortgage, the original mortgagor must be present at trial); Hazard, supra note 35 , at 1258-59 (discussing Lord Nottingham's contention that absent parties are not bound by judgments).

${ }^{40}$ See JOHN MITFORD (LORD REDESDALE), PLEADINGS IN CHANCERY 202 (New York, John S. Voorhies, 3d ed. 1833) ("[W]here one general legal right is claimed against several distinct persons, a bill may be brought to establish the right." (citation omitted)).

${ }^{41}$ See, e.g., Cowslad v. Cely, Prec. Ch. 83, 83, 24 Eng. Rep. 40, 40 (Ch. 1698) (holding that a suit may proceed against one executor where service could not have been effected on a foreign executor).

${ }_{42}$ See, e.g., Quintine v. Yard, 1 Eq. Ca. Abr. 74, 74, 21 Eng. Rep. 886, 886 (Ch. 1702) (ruling that in a suit to recover an annuity from a will, the defendant's demurrer for lack of proper parties was denied since the other two obligators were out of the jurisdiction).

${ }^{43}$ See, e.g., Darwent v. Walton, 2 Atk. 510, 511, 26 Eng. Rep. 707, 708 (Ch. 1742) (stating that in a joint demand, when one party is outside the jurisdiction, the other is liable for the whole demand).

${ }^{44}$ See, e.g., Madox v. Jackson, 3 Atk. 406, 407, 26 Eng. Rep. 1034, 1035 (Ch. 1746) (holding that an obligee may recover against two obligators when the third was dead and his estate insolvent); Heath v. Percival, 1. P. Wms. 682, 684, 24 Eng. Rep. 570, 571 (Ch. 1720) (stating that an obligee may recover a debt even though one of the two obligators was bankrupt). 
those who remained; or, where the identity of an absent party was unknown, his presence would be excused. ${ }^{45}$ Taken together, these constituted what can be called the "impossibility exception": When compliance with the Necessary Party Rule was impossible as a practical matter, the rule was relaxed.

The impossibility exception also covered situations in which interested parties were so numerous that it was practically impossible to join them all. This problem of "numerousness" was a chief antecedent of the modern class suit. When confronted with parties too numerous to be joined, the chancellor sometimes simply allowed such suits to be maintained without joinder of all such "interested" parties. ${ }^{46}$ But as a general principle, as we shall see, courts tried to establish the principle that the absentee members of a numerous group would be regarded as parties through the medium of representation.

The problem was thus: If the absentees are necessary parties without whom a decree ordinarily would not be entered, but the absentees cannot be made parties, then what is the effect on those parties of a decree entered in their absence? Under the Necessary Parties Rule as applied until about 1780 , cases involving one or a few absentees held that the absentees need not be joined and that they were not bound. ${ }^{47}$ Later, this formula was inverted, and it was held that the absentee had to be joined because he would nonetheless be bound-the Indispensable Party Rule. ${ }^{48}$ Both the old, flexible Necessary Party Rule and the subsequent inflexible, Indispensable Party Rule, however, shared a premise about binding an absentee member. This premise was that a person not a party to a suit should not be bound by a

${ }^{45}$ See Bowyer v. Covert, 1 Vern. 95, 95, 23 Eng. Rep. 337, 337 (Ch. 1682) (denying a demurrer for lack of parties where the plaintiff did not know the identity of the other executor).

${ }^{46}$ See, e.g., Attorney Gen. v. Wyburgh, 1 P. Wms. 599, 24 Eng. Rep. 534 (Ch. 1719). In this case, the Attorney General brought a bill to establish the entire charge against only a few of the devisees. These defendants objected that all of the owners of the charged estates should be joined. The court held that the defendants' remedy was to bring a bill for contribution later, but nonetheless appointed a master to determine the amount of arrearage and to "inquire whether the lands were liable." To the same effect are Attorney Gen. v. Shelley, 1 Salk. 163, 91 Eng. Rep. 151 (Ch. 1712), and Attorney Gen. v. Jackson, 11 Ves. 365, 32 Eng. Rep. 1128 (Ch. 1805). In the latter case, Lord Redesdale, sitting as Chancellor, held that "the rule of pleading is, that the Charity may bring any one of the estates before the Court ..." 11 Ves. at 369,32 Eng. Rep. at 1130 (emphasis added), and expressly reserved the question of the effect on absent parties.

${ }^{47}$ See Hazard id. at 1257-62 (detailing situations in which joinder of necessary parties was excusable, and articulating the "settled law" that an absentee was not bound).

${ }^{48}$ See id. at 1259-60 (discussing situations in which judgments would bind absentee members); id. at 1265-66 (discussing Lord Hardwick's approach of the binding effect of the judgment on all absentee members when including them in the suit was not possible). 
purported determination of his rights in such a suit. As has long been said, it is a first principle of justice that a person have notice and an opportunity to be heard in the determination of her rights. ${ }^{49}$

The same problem arose in situations involving numerous parties. Several patterns of cases dealt with the effect of a decree in such situations. Although some of the cases involved numerous claimants while others involved numerous obligors, most of the cases involved the question of whether the suit could proceed without the absentees-the view of a class suit from the prospective or ex-ante perspective, presenting what we now call the question of joinder of necessary parties. A few of the cases, most of them appearing later in historical sequence, involved the effect of the decree on the absentees-the retrospective or ex-post view, presenting what we now call the question of res judicata. The class suit cases presenting the necessary parties problem and those presenting the res judicata problem were, however, considered to involve the same issue-whether the absentees were bound. This is evidenced by the fact that the reason offered in the necessary parties cases for allowing the case to proceed despite the lack of complete joinder was the proposition that the absentee members of the class would be bound through the parties who represented them. ${ }^{50}$

\section{B. Early Representative Suits}

A large proportion of the early numerous parties cases can be classfied in three categories: bills of peace involving a common benefit to or burden upon the members of the group, often relating to real property, cases involving a group having creditor claims against a debtor or legatee claims against an estate, and cases involving unincorporated associations.

49 See, e.g., Martin v. Wilks, 490 U.S. 755, 761 (1989) (reiterating the holding of Hansberry $v$. Lee that "one is not bound by a judgment ... in which he is not designated as a party or to which he has not been made a party by service of process" (citation omitted)).

${ }^{50}$ Comparison of the Indispensable Party Rule, as it evolved in the first half of the nineteenth century, with the Class Suit Rule in the same period reveals a curious paradox. The Indispensable Party Rule stated that when the absentees were few in number the action could not proceed without them, lest they be bound by the decree, while the Representative Suit Rule stated that if the absentees were numerous, the action could proceed without them because they would be bound. Compare Shields v. Barrow, 58 U.S. 129, 141, 17 How. 137, 150 (1854) (refusing to uphold the rescission of a contract where four of the six parties in the contract were not within the jurisdiction of the lower court), with Smith v. Swormstedt, 57 U.S. $288,302,16$ How. 307, 322 (1853) (stating that "[f]or convenience, therefore, and to prevent a failure of justice, a court of equity permits a portion of the parties in interest to represent the entire body, and the decree binds all of them the same as if all were before the court"). 


\section{Bills of Peace}

The earliest cases involved bills of peace concerning a common benefit or burden. In these situations, a multiplicity of litigation would result unless a bill of peace was permitted. As its name implies, the raison d'etre of the bill of peace was prevention of multiple suits over a common question by bringing all the disputants into one suit. Not all of the bill of peace cases, however, implicated the necessary parties problem. Most of these cases involved claims that could have been satisfactorily litigated without the absentees, apart from the burden of repetitive litigation. Each of the many claims could have been coherently litigated without reference to any other claim. Analytically these proceedings are therefore "common question" class suits, which today we classify as the "(b)(3)" type of suit. ${ }^{51}$ That is, they involved claims such that a resolution for or against an individual claimant would not implicate rights of other claimants, other than the fact that inconsistent resolutions of the issue would result in unequal treatment of the claimants. ${ }^{52}$

The decisions in the bill of peace cases upheld the representative device to the extent that joinder was concerned, but did not advance any theory of representation by which the absentees would be bound. Professor Yeazell suggests that at least some of these cases involve actual participation by a preexisting group that had conferred representative authority on some of their numbers to conduct the litigation in behalf of all. ${ }^{53}$ That analysis certainly covers a good number of the cases. The best example of such cases is that of villagers having identical claims to common land as against a village landlord where, as Professor Yeazell has suggested, the villagers undoubtedly had a real affiliation with each other as well as being a class in a procedural sense. ${ }^{54}$ On that basis, these cases can be considered as involving, not

${ }^{51}$ FED. R. CIV. P. 23(b)(3) (stating that "questions of law or fact common to the members of the class predominate ....”').

52 For modern analogues, see, for example, Eisen v. Carlisle, 417 U.S. 156, 160-66 (1974), involving a proposed class of several million stockholders alleging that they were charged excessive brokerage fees in violation of antitrust laws, and Vasquez $v$. Superior Court, 484 P.2d 964, 966-67 (Cal. 1971), involving a proposed class of consumers alleging fraudulent misrepresentation against several finance companies and a seller of freezers.

${ }^{53}$ See Yeazell, Group Litigation and Social Context, supra note 12, at 877-81 (illustrating situations in which numerous litigants were represented by a select few).

${ }^{54}$ See id. at 877 (arguing that most groups involved in such early lawsuits "existed as social entities independent of the lawsuit"). The affiliation, of course, would be the shared "fate" of living one's life in the same village. 
instances of mere common victimization, but prototypes of the unincorporated association type of class suits that later appeared. ${ }^{55}$

The bill of peace cases are perhaps the first recognizable expression of class suit doctrine. In these decisions, however, there was no coherent theory of representation or firm view as to the effect of a decree on absentees. One very early decision indicated that the bill could not be maintained without joinder of the absentees; ${ }^{56}$ another early case said that the bill could be maintained but that non-parties who had an interest in the bill could not be bound. $^{57}$ Nevertheless, even as early as the late seventeenth century, there were a few cases saying that the absentees would be bound.

Chief among the cases indicating that absentee members of a numerous group can be bound through representation is the well-known case of Brown v. Vermuden. ${ }^{58}$ This case presented the following scenario: The vicar of a parish initially had sued to establish a right to a tithe from all mining operations in his parish, the tithe being essentially a land tax to support the parish church. The miners of the parish appointed four representatives to defend the suit, and a decree was eventually rendered in favor of the vicar. Plaintiff Brown thereafter succeeded to the vicarship and some years later sought to enforce the decree against Vermuden, another miner; that is, Vicar Brown sought to collect a subsequently accruing tithe on the basis of liability established in the first suit. Vermuden defended on the ground that he had not been a party to the earlier action. The court held that Vermuden was obligated to pay the tithe on the basis of the earlier decree, stating that otherwise suits would be "infinite, and impossible to be ended." 59

Similarly, How v. Tenants of Bromsgrove ${ }^{60}$ affirmed the use of a bill of peace to prevent a multiplicity of suits in a dispute between a lord and his

55 See RESTATEMENT (SECOND) OF JUDGMENTS $§ 61 \mathrm{cmt}$. a (1982) (illustrating liability against associations with multiple members in the common law).

${ }^{56}$ See Hudson v. Fletcher, Rep. T. Finch 114, 114, 23 Eng. Rep. 62, 62 (Ch. 1673) (holding that it was necessary to add the other parties involved for a bill to be examined).

57 See Thirveton v. Collier, 1 Ch. Cas. 48, 48, 22 Eng. Rep. 688, 688 (Ch. 1664) (holding that those who had an interest in the bill, but were not parties to an Agreement for Inclosure, could not be bound).

${ }_{58} 1$ Ch. Cas. 272, 22 Eng. Rep. 796 (Ch. 1676). Brown v. Vermuden has been recurrently cited in the subsequent evolution of class suit doctrine, not least significantly in Hansberry $v$. Lee, 311 U.S. 33, 42 (1940). See also Brown v. Booth, 2 Vern. 184, 184, 23 Eng. Rep. 720 , 721 (Ch. 1690) (holding that miners not originally parties to a suit were nevertheless obligated to pay the plaintiff and his successors); $c f$. Anonymous, 1 Ch. Cas. 269, 270, 22 Eng. Rep. 795,795 (Ch. 1675) (holding that a corporation could represent a larger group in a suit so as to avoid confusion).

59 Brown, 1 Ch. Cas. at 272, 22 Eng. Rep. at 797.

${ }^{60} 1$ Vern. 22, 22, 23 Eng. Rep. 277, 277 (Ch. 1681) (holding that "[b]ills of peace to prevent multiplicity of suits are proper in equity"); see also Ewelme Hosp. v. Andover, 1 Vern. 
tenants over hunting rights in manorial lands. This could be considered either as an association case, the tenants obviously having a preexisting group identity, ${ }^{61}$ or as a case involving individual parallel claims to property; that is, a "common question" type of case.

In City of London v. Perkins, ${ }^{62}$ the Mayor of London brought a bill against an importer to collect a customs tax on cheese. Claiming an exemption as a freeman, the defendant refused to pay the duty. It was held without much explanation that the defendant was bound by the decision in two earlier cases involving the same issue against similarly situated defendants. ${ }^{63}$

In 1737, the famous case of Mayor of York v. Pilkington ${ }^{64}$ was decided. In behalf of the residents of York, the mayor claimed an exclusive right to fish a local river. He sought a bill of peace and an accounting for fish already taken against five lords of nearby riparian manors. The defendants demurred to the joinder of parties. They argued that, although bills of peace had been allowed where "general rights" were asserted, the rights of each defendant in this case were claimed on "distinct" grounds; hence, no issue could be framed that would settle the rights of all parties. Translating this objection into modern procedural rubric, the defendants argued that the situation did not present a problem of necessary parties but only one of permissive joinder of defendants. Since joinder of the absentees was unnecessary to adjudicate the interests of those already joined, a representative suit was inappropriate. Citing City of London v. Perkins, ${ }^{65}$ Lord Hardwick reasoned that the several nature of the rights claimed by defendants was irrelevant. Rather, the existence of numerous adverse claimants, and the consequent danger of multiple suits, was sufficient to establish equity jurisdiction for the bill of peace. 66

Looking at these cases in modern analytic terms, one can see that most of them involved prospective or ex-ante joinder problems concerning nu-

266, 267, 23 Eng. Rep. 460, 461 (Ch. 1684) (noting that in cases in which multiple suits were brought a bill of peace was proper to prevent a multiplicity of suits).

${ }^{61}$ See Yeazell, Group Litigation and Social Context, supra note 12, at 869-73 (asserting that sixteenth- and seventeenth-century cases of group litigation involved members of rural agricultural communities).

623 Bro. P.C. 602, 602, I Eng. Rep. 1524, 1524 (Parl. 1734).

${ }^{63}$ See id. at 606-07,1 Eng. Rep. at 1527 (holding that the defendant should pay the duty for all imported cheese).

${ }_{64}$ West. T. Hard. 293, 296-97, 25 Eng. Rep. 946, 947-48 (Ch. 1737) (overruling the defendant's demurrer and noting that the main issue to be decided was the plaintiff's general right upon which the defendants could each make their distinct defenses).

${ }^{65}$ Perkins, 3 Bro. P.C. at 602, 1 Eng. Rep. at 1524.

${ }^{66}$ See Pilkington, West T. Hard. at 296, 25 Eng. Rep. at 947 ("[B]ut because a great number of actions may be brought, the Court suffers such bills, though defendants might make distinct defences ... I think, therefore this bill is proper."). 
merous parties; only one of them, City of London $v$. Perkins, ${ }^{67}$ addressed res judicata effects on absentees. Most if not all of the cases involved preexisting social groups, suggesting the point made by Professor Yeazell ${ }^{68}$ that these cases involve issues analogous to what in modern times is litigation involving local or private government. ${ }^{69}$ In this connection, it is noteworthy that the contested substantive issue in each instance did not concern individual conduct, as such, but rather the legal standard by which such conduct was commonly governed-the tithe, the right of fishery, and liability for customs duty.

These early cases can fairly be read as procedural improvisations whereby the court could treat groups-fellow tenants, fellow miners, fellow merchants-as some kind of set or entity for procedural purposes. Such a theme certainly seems implicit in most of the decisions. While it is risky to interject modern analysis into pre-modern situations, it does appear that Chancery in the late seventeenth and early eighteenth centuries felt reasonably confident about the fairness of adjudicating rights of absentees where the absentees belonged to a preexisting group and some members of the group were before the court as litigants.

Equivocation and contradiction nevertheless persisted. A mideighteenth-century decision by Chancellor Hardwick held that all other tenants claiming a right claimed by the plaintiff were not necessary parties, but also said that neither would they be bound by the decree. ${ }^{70}$ Yet in a case decided the same year, the Chancellor held that in a bill to account for fees, all parties who wished to be bound had to appear before the court. ${ }^{71}$

673 Bro. P.C. at 605-07, 1 Eng. Rep. at 1526-27.

${ }^{68}$ See Yeazell, Group Litigation and Social Context, supra note 12, at 868-76 (discussing the history of the class action lawsuit and focusing on the social position of group litigants since the infancy of class action suits).

${ }^{69}$ See id. at 892-93 (describing how the courts engaged in a legislative function due to their position as an administrative arm of the Crown).

${ }^{70}$ See Pawlet v. Bishop of Lincoln, 2 Atk. 296, 296, 26 Eng. Rep. 581, 581 (Ch. 1742) (illustrating concepts regarding the use of compulsory joinder in early case law and standing for the proposition that allowing joinder of parties was desirable and necessary).

${ }^{71}$ See Poore v. Clark, 2 Atk. 515, 515-16, 26 Eng. Rep. 710, 710 (Ch. 1742) ("[ $]$ f you draw the jurisdiction out of a court of law, you must have all persons parties before this court, who will be necessary to make the determination complete, and to quiet the question." (citing Pawlet v. Bishop of Lincoln, 2 Atk. 296, 296, 26 Eng. Rep. 581, 581 (Ch. 1742))). 


\section{Creditor and Legatee Bills}

Toward the latter part of the eighteenth century, Chancery began to apply the Necessary Parties Rule with greater inflexibility. ${ }^{72}$ In cases involving "numerous parties," a rigorously applied Necessary Parties Rule would have made it practically impossible to bring a controversy to final judgment. In those days, complicated equity suits could take decades to resolve, ${ }^{73}$ and equity procedure required that, if a party died, the suit in effect had to be commenced anew by a bill of revivor. This meant that a suit involving many parties stood a good chance of never coming to decree. ${ }^{74}$ To avoid this difficulty, resort was had to the principle of representation adumbrated in the bill of peace cases.

The cases that most clearly manifest this development are those of creditor and legatee bills. The typical case of this type involved a bill in behalf of all creditors or all legatees for an accounting and for payment of debts or legacies out of the estate of the debtor or decedent. ${ }^{75}$ Both types of bills involved an initial decree for an accounting by a master. Upon being appointed, the master marshaled assets, advertised for creditors and legatees, listed and paid creditors and legatees who had appeared and proved their claims, listed absent creditors and legatees who apparently had valid claims but who had not appeared, and rendered his account to the chancel-

72 See supra note 35 and accompanying text (tracing the historical developments of modern joinder law and illustrating them with examples of seventeenth- and eighteenth-century Chancery cases).

${ }^{73}$ See, e.g., ChARLES DICKENS, BLEAK House 1-9 (London, MacDonald \& Sons n.d.) (1853) (using Jardyce v. Jardyce to comment on the lengthy process of the English chancery court system).

${ }^{74}$ See JOSEPH STORY, COMMENTARIES ON EQUITY PLEADINGS $\$ \$ 94-97$, at 93-98 (2d ed. 1840). A sense of the delay and frustration involved is conveyed in the jurisprudence under Rule 25 of the Federal Rules of Civil Procedure before its amendments in 1961 and 1963. See generally Charles ALAN WRIGHT \& ARTHUR R. MILlER, FEDERAL PRACTICE AND PROCEDURE \$§ 1951-62 (1982).

${ }^{75}$ Creditor bill cases include, for example, Weld v. Bonham, 2 S. \& S. 91, 57 Eng. Rep. 280 (Ch. 1824), involving a bill to execute the trusts of a deed in payment of debts due to the plaintiffs and Leigh $v$. Thomas, 2 Ves. Sen. 312, 28 Eng. Rep. 201 (Ch. 1751), involving a bill for the account of prize money brought by two agents who were part of a ship's crew. Legatee cases include, for example, Manning v. Thesiger, 1 S. \& S. 106, 57 Eng. Rep. 43 (Ch. 1822), involving a suit brought by plaintiffs in behalf of themselves and to their legatees under a will to discharge the appointed trustee and Craker v. Parrott, 2 Ch. Cas. 228, 22 Eng. Rep. 921 (Ch. 1677), involving a bill brought by a widow to enforce the legacy left by her husband. The legatee's bill had to be brought against the administrator or executive. See Peacock v. Monk, 1 Ves. Sen. 127, 131-33, 27 Eng. Rep. 934, 937-38 (Ch. 1748) (holding that it was unnecessary to make persons other than the executor parties to the estate since he could defend for himself, creditors, and legatees); Humphreys v. Humphreys, 3 P. Wms. 349, 350, 24 Eng. Rep. 1096, 1096-97 (Ch. 1734) (holding that to take account of a person's estate, his executor or administrator must be made a party to the bill). 
lor. Thereafter, a final decree was issued. ${ }^{76}$ The final decree directed payment of creditors and, in the case of a legatee bill, directed payment to legatees out of any residue. The decree operated as a discharge of the executor or administrator. ${ }^{77}$

This type of representative suit evolved in significant part to avoid difficulties created by the Necessary Party Rule. ${ }^{78}$ The creditor or legatee who brought the suit could represent the creditors or legatees whose joinder was impractical. Some of the decisions also reasoned that the purpose was to avoid the cost to the decedent's estate that would result from defending numerous suits by individual creditors, a rationale derived from the bill of peace type of representative proceeding. ${ }^{79}$ Other cases made reference to the need to prevent one creditor from gaining a preference over others, ${ }^{80}$ and

${ }^{76}$ See David v. Frowd, I My. \& K. 200, 208-11, 39 Eng. Rep. 657, 660-61 (M.R. 1833) (reviewing extensively the practice for resolving creditor and legatee bills); Gillespie v. Alexander, 3 Russ. 130, 136-37, 38 Eng. Rep. 525, 528 (Ch. 1827) (same); see also Brooks v. Reynolds, Dick. 603, 603, 21 Eng. Rep. 406, 406 (Ch. 1782) (explaining the procedures by which account is taken and decrees issued); Douglas v. Clay, Dick. 393, 393-94, 21 Eng. Rep. 322, 322 (Ch. 1767) (same).

77 See Curre v. Bowyer, 3 Madd. 456, 456, 56 Eng. Rep. 572, 572 (V.C. 1818) (holding that a creditor who proceeds at law against an executor after a decree has been issued is in contempt of court). But see Angell v. Haddon, 1 Madd. 529, 530, 56 Eng. Rep. 194, 194 (V.C. 1816) (allowing a creditor to prove his debt under a decree of a creditor's bill even though the funds in question had already been apportioned among other creditors); Farrell v. Smith, 2 Ball \& Beatty 337, 342 (Ir. H. Ct. 1813) ("Where this Court has taken the Management of Assets from the Executor into its own hands, it will not permit him to be charged, for what has been done in pursuance of its Directions.").

${ }^{78}$ See Weld, 2 S. \& S. at 193, 57 Eng. Rep. at 281 ("[T] to make it practicable to prosecute a suit, if they are all made parties."); Manning 1 S. \& S. at 106, 57 Eng. Rep. at 43 (holding that when a bill is filed by many appointees, the court may dispense of the rule requiring all to be named parties to the suit); Lloyd v. Loaring, 1 Ves. Jun. Sup. 656, 657, 34 Eng. Rep. 966, 966 (Ch. 1802) (holding that the rule requiring all parties interested in a suit to appear before a court may be dispensed with). But see Morse v. Sadler, 1 Cox 352, 352, 29 Eng. Rep. 1199, 1199 (Ch. 1787) ("[L]egatees out of personal estate only, need not be parties, but every person claiming an interest out of real estate must be before the Court.").

${ }^{79}$ Law v. Rigby, 4 Bro. C.C. 60, 63, 29 Eng. Rep. 779, 780 (Ch. 1792) ("It certainly would not be right to load the estate with the expence of two causes ....."); see also Pott v. Gallini, I S. \& S. 206, 209-10, 57 Eng. Rep. 83, 84 (V.C. 1823) (explaining that a defendant incurs unnecessary expense when he must answer two complaints making a claim against the same account).

${ }^{80}$ See Brooks v. Reynolds, 1 Bro. C.C. 183, 184, 28 Eng. Rep. 1070, 1071 (Ch. 1782) (holding that a creditor's suit against an executor binds the other creditors such that creditors suing subsequent to the original suit will be enjoined from suing) (citing Martin v. Martin, 1 Ves. Sen. 211, 27 Eng. Rep. 988 (Ch. 1748-49)); Douglas, Dick. at 394, 21 Eng. Rep. at 322 (granting an injunction against a creditor who brought suit against the plaintiff in an attempt to gain a preference over other creditors). In fact, a creditor was virtually compelled to bring the action for his debt in behalf of all creditors, to prevent preferences. See Attorney Gen. v. Cornthwaite, 2 Cox 44, 45, 30 Eng. Rep. 21, 21 (Ch. 1788) (requiring that the Master account 
to minimize vexation of executors through multiple suits, ${ }^{81}$ which would discourage acceptance of appointments as executors. These explanations all imply that the absentees are bound by the decree.

The creditor bill cases certainly did not involve a preexisting group that could be regarded in any sense as an association. Ordinarily, the only tie among creditors would be their unpaid claims against the debtor or decedent-that is, their common victimization. As for legatees, no doubt they usually had family ties, but they also must have had conflicts of interest among themselves. Possibly for these reasons, the creditor and legatee cases generated the first explicit consideration of what we now call "fairness" and "adequacy" of representation in "numerous parties" situations.

The clear premise of the creditor and legatee bills was that the plaintiff had a representative status. Accordingly, it was held that inasmuch as the bill was brought in behalf of all creditors, the decree was in the nature of a judgment for all creditors. ${ }^{82}$ For the same reason, a creditor's bill did not abate upon the death of the plaintiff; any other creditor could renew the suit by supplemental bill, rather than having to commence a new suit. ${ }^{83}$ In

for a testator's other debts before payment of a debt to a single creditor); Bedford v. Leigh, Dick. 707, 708, 21 Eng. Rep. 446, 446-47 (Ch. 1785) ("I ha[ve] never heard of a decree upon a bill by a single creditor, not on behalf of himself and the rest, go to real assets.").

${ }^{81}$ See Fielden v. Fielden, 1 S. \& S. 255, 257, 57 Eng. Rep. 102, 103 (V.C. 1822) (holding that the court "should have protected the executor" from multiple creditors; Brooks, 1 Bro. C.C. at 185, 28 Eng. Rep. at 1072 ("[T]he reason why the injunction is granted is this, that this Court, having taken the fund into its own hands, will not permit the executor to be pursued at law."); Farrell, 2 Ball \& Beatty at 341-42 (rejecting the plaintiff's bill on the grounds that the court had already administered the estate and on the grounds that no executor would be safe if he were liable to answer in a case such as this).

${ }^{82}$ See Lord v. Wormleighton, Jac. 148, 149-50, 37 Eng. Rep. 806, 806-07 (Ch. 1821) (granting an executor's motion for an injunction against a creditor such that the creditor was restrained from proceeding at law pending the administration of the estate); Terrewest v. Featherby, 2 Mer. 480, 481, 35 Eng. Rep. 1024, 1024 (Ch. 1817) (refusing to grant the defendant's motion for an injunction against the plaintiff's suit on the grounds that delaying the plaintiff's suit would be a disservice to him, and such a delay increased the chance that the plaintiff would not be able to recover from the executor de bonis propriis for a false plea of plene administrauit); Paxton v. Douglas, 8 Ves. 520, 520, 32 Eng. Rep. 456, 456 (Ch. 1803) ("Nothing is better settled, than that, where this Court has made a decree for administration of assets, that decree is in nature of a judgment for all creditors."). As stated in Handford v. Storie:

After a[ $\mathrm{n}$ initial] decree [the plaintiff creditor] cannot, by his conduct, deprive other persons of the same class of the benefit of the decree.... The reason of the distinction is, that before decree no other person of the class is bound to rely upon the diligence of him who has first instituted his suit ....

2 S. \& S. 196, 198, 57 Eng. Rep. 320, 321 (V.C. 1825).

${ }^{83}$ The court in Houlditch $v$. Donegall was clear:

Where a bill is filed by a person on behalf of himself and a class of other persons standing in the same circumstances, and the suit, after decree, abates by his death, or is deserted by him or his representatives, it is almost a matter of course to permit an- 
working out the implications of the fact that the plaintiff was a representative, it was recognized that the representative had fiduciary obligations. Thus, it was held that a mortgage creditor could not file a bill in behalf of general creditors, ${ }^{84}$ and that creditors were not allowed to use the bill to establish the priority of their claims as against other creditors. ${ }^{85}$ Upon the same principle, in legatee bills, a contingent remainderman defendant could not bind other remaindermen, ${ }^{86}$ nor could a specific legatee bring a bill in behalf of residuary legatees. ${ }^{87}$

The procedural mechanics in these suits also reveal how absent parties would be affected. It will be recalled that the creditor's bill proceeding involved two decrees-the initial decree directing an accounting and the appointment of the master, and the final decree directing payment of claims and discharging the executor or administrator. After the initial decree, no creditor or legatee could proceed by an action at law to collect his debt or legacy; an attempt to do so would provoke an injunction against such an action. ${ }^{88}$ The claimant was remitted to coming in under the initial decree and

other person reported by the Master to be one of that class, to take up the proceedings by a supplemental bill.

1 S. \& S. 491, 494, 57 Eng. Rep. 194, 196 (V.C. 1823); see also Boddy v. Kent, 1 Mer. 361, 364-65, 35 Eng. Rep. 707, 708-09 (Ch. 1816) (indicating in dicta that the death of one creditor does not cause an abatement because the representatives of the deceased creditor may "come in under the Decree in common with the other creditors").

${ }^{84}$ See Weld v. Bonham, 2 S. \& S. 91, 93, 57 Eng. Rep. 280, 280 (V.C. 1824) ("If there be special circumstances ... which make it fit that the joint creditors ... should be more distinctly represented ... a proper application must be made ...."); Cockburn v. Thompson, 16 Ves. Jun. 321, 327-28, 33 Eng. Rep. 1005, 1008 (Ch. 1809) ("[A]nd I should upon principle find the means, if not supplied by precedent, of giving a creditor ... the opportunity of supporting his interest better than the Plaintiff could." (citations omitted)); see also Bedford v. Leigh, Dick. 707, 708, 21 Eng. Rep. 446, 446-47 (Ch. 1785) ("I ha[ve] never heard of a decree upon a bill by a single creditor, not on behalf of himself and the rest, go to real assets."); Burney v. Morgan, 1 S. \& S. 358, 362, 57 Eng. Rep. 144, 145 (V.C. 1823) ("A mortgagee has no common interest with the creditors ... and cannot sue on their behalf.").

${ }^{85}$ See Newton v. Egmont, 5 Sim. 130, 137, 58 Eng. Rep. 286, 289 (V.C. 1832) ("In this case, where the question is priority of charge, the very nature of the question makes it necessary that all the creditors should be parties.").

${ }^{86}$ See Pelham v. Gregory, 1 Eden. 518, 28 Eng. Rep. 786 (Ch. 1760). The court makes a very interesting analysis in Pelham, in which it states: "It may be convenient in the present case to the plaintiffs, but no complaisance should dwell within these walls; and when with one eye I look upon the convenience of plaintiffs, I must with the other as steadily observe the inconvenience of defendants." 1 Eden. at 521, 28 Eng. Rep. at 788.

${ }^{87}$ See Atwood v. Hawkins, Rep. T. Finch 113, 113, 23 Eng. Rep. 62, 62 (Ch. 1673) (granting the defendant's demurrer as to the plaintiff's motion demanding an account of the surplus of their father's estate because, as residuary legatees, they were not parties to the suit).

${ }^{88}$ See Curre v. Bowyer, 3 Madd. 456, 456, 56 Eng. Rep. 572, 572 (V.C. 1818) (holding that a creditor's attempt to proceed at law after notice of the decree was in the nature of a contempt of court and indicating that upon a motion for an injunction, the Vice-Chancellor would go so far as to refuse the creditor the costs of the further proceedings at law and the costs of the application); Brooks v. Reynolds, 1 Bro. C.C. 183, 185, 28 Eng. Rep. 1070, 1072 
proving his debt before the master. ${ }^{89}$ This result, which obviously had great practical utility, was justified in procedural terms by the propositions that the creditor had an existing and efficient remedy in Chancery ${ }^{90}$ and that, by virtue of representation through the plaintiff, the absent parties were in a sense before the court. ${ }^{91}$ It was but a small step to hold that these parties were also precluded from proceeding against the executor after the final decree. $^{92}$

(Ch. 1782) (granting an injunction to restrain a creditor from proceeding at law); Douglas v. Clay, Dickens 393, 394, 21 Eng. Rep. 322, 322 (Ch. 1767) (enjoining a creditor from proceeding at law after the decree for satisfaction of the creditors); see also Rush v. Higgs, 4 Ves. Jun. 638, 643, 31 Eng. Rep. 329, 331 (Ch. 1799) (stating that no injunction will issue against an action at law until the initial decree for an accounting has actually been effected).

${ }^{89}$ See Pott v. Gallini, 1 Sim. \& St. 206, 209, 57 Eng. Rep. 83, 84 (V.C. 1823) ("Where there is a prior decree, and a second suit for the same accounts, and no further relief that can be had ... under the first suit, the proper course is ... that the proceedings ... be stayed, and that the Plaintiff may go before the Master in the first suit."); Law v. Rigby, 4 Bro. C.C. 60 , 63, 29 Eng. Rep. 779, 780 (Ch. 1792) ("It certainly would not be right to load the estate with the expense of two causes, if one is sufficient."); Brooks, 1 Bro. C.C. at 185, 28 Eng. Rep. at 1071-72 (granting an injunction because "the creditors here may come in before the Master ....").

${ }^{90}$ See Rigby, 4 Bro. C.C. at 63, 29 Eng. Rep. at 780 (overruling a demurrer in a second suit because "the creditors must be content to come in under a decree [made in the initial] cause"); see also Rush v. Higgs, 4 Ves. Jun. at 643, 31 Eng. Rep. at 331 ("I cannot stop a creditor at law, unless there is a decree, under which he can go in."); Craker v. Parrott, 2 Chan. Cas. 228, 230, 22 Eng. Rep. 921, 922 (Ch. 1677) (holding that the decedent's issues could come in before the master even though they were not party to the initial suit).

${ }^{91}$ See Cockburn v. Thompson, 16 Ves. Jun. 321, 325-30, 33 Eng. Rep. 1005, 1007-08 (Ch. 1809) (admitting the general rule that all persons with an interest in the suit ought to be parties but holding that the plaintiff's inability to bring forward all persons with an interest in the suit should not prevent the suit from proceeding); Adair v. New River Co., 11 Ves. Jun. $429,443-44,32$ Eng. Rep. 1153, 1158-59 (Ch. 1805) ("[W] all parties having an interest in the case], the rule shall not be pressed."); see also Neve v. Weston, 3 Atk. 557, 557, 26 Eng. Rep. 1121, 1121 (Ch. 1747) ("A man who comes in before a Master under a decree, is quasi a party to that suit ....").

${ }^{92}$ A few eighteenth-century cases involved absent parties attempting to bring suit after the final decree, but these cases involved long lapses of time between the decree in the first suit and the absentee's filing of the second action. Hence, they may rest on a principle of laches rather than preclusion. See Pearson v. Belchier, 4 Ves. Jun. 627, 628, 31 Eng. Rep. 323, 323 (Ch. 1799) (final decree in the first suit in 1752; absentees' suit filed in 1781 and heard in 1799); Farrell v. Smith, 2 Ball \& Beatty 337, 342 (Ir. H. Ct. 1813) (final decree in 1803; absentees' suit filed in 1811 and heard in 1813). In this period it was often stated as dictum that there could be no action against the administrator after a final decree. In the few cases involving a creditor or legatee who had failed to claim under the original bill through no fault of his own, and who was not guilty of laches in a second suit, the absentee was usually held not to be precluded. That the preclusive effect in a legatee bill was unsettled as late as 1804 is illustrated by Lord Redesdale's remarks in Giffard v. Hort:

Under this impression therefore I think I ought to let the cause stand over ... to the House of Lords. If the lord shall think [the absentee] not entitled to appeal from that [earlier] decree, it must be because they think him not bound by it: and ... I shall not consider myself bound by that [final] decree.... 
On the other hand, the courts carefully attempted to safeguard the rights of absent parties. If an absent creditor or legatee appeared at any time before the final decree, a new account would be prepared that included the latecomer's claim. ${ }^{93}$ Also, at least in legatee cases, an absent party could recover after a final decree if he appeared before actual distribution had been completed. ${ }^{94}$

In 1833 , in David v. Frowd, ${ }^{95}$ the court squarely faced the situation of an absent next of kin who presented a claim after a final decree and completion of the distribution. Reviewing the practice in representative suits at length, the court held that the absent legatee could be precluded. Notably, the basis of preclusion was estoppel by laches, not res judicata. As the court explained:

Upon the application of any person claiming to be interested, the Court refers it to the Master to inquire who are creditors, and who are the next of kin.... Such proceedings having been taken, the Court will protect the administrator against any future claim. But it is obvious that the notice given by advertisements may, and must, in many cases, not reach the parties really entitled .... [A]nd it would be the height of injustice that the proceedings of the Court, wisely adopted with a view to general convenience, should have the absolute effect of conclusively transferring the property of the true owner to one who has no right to it.

It is for this reason that... if a creditor does not happen to discover the proceedings in the Court until after the distribution has been actually made by the order of the Court amongst the parties having by the Master's report an apparent title, although the Court will protect the administrator who has acted under the orders of the Court; yet, upon a bill filed by this creditor against the parties to whom the property has been distributed, the Court will, upon proof of no wilful default on the part of such creditor, and no want of reasonable diligence on his part, compel the parties Defendants to restore to the creditor that which of right belongs to him ....

....

It is argued also that the case is extremely hard upon the party who is to refund, for that he has full right to consider the money as his own, and may have spent it, and that it would be against the policy of the law to recall money which a party has obtained by the effect of a judgment upon a litigated title. There is here no judgment upon a litigated title; the party, who now claims by a paramount title, was absent from the Court, and all that is adjudged is, that

1 Sch. \& Lefr. 386, 409 (Ir. H. Ct. 1804).

${ }^{93}$ See Angell v. Haddon, 1 Madd. 529, 530, 56 Eng. Rep. 194, 194 (V.C. 1816) (allowing a creditor to prove his debt after the apportionment of the property amongst the initial creditors on the condition that the creditor pay for the cost of his application and the cost in recasting the apportionment of the property among all the creditors).

${ }^{94}$ See Gillespie v. Alexander, 3 Russ. 130, 136, 38 Eng. Rep. 525, 528 (Ch. 1827) (permitting a creditor to prove his debt "as long as there happens to be a residuary fund in court or in the hands of the executor, and to pay him out of that residue").

${ }^{95}$ Id. 200, 39 Eng. Rep. 657 (Ch. 1833). 
upon an inquiry, in its nature imperfect, parties are found to have a prima facie claim, subject to be defeated upon better information. The apparent title under the Master's report is in its nature defeasible. ${ }^{96}$

As of this stage of development (about 1830), the English law regarding creditor and legatee bills could fairly be summarized as follows: (1) the plaintiff was a representative, with the result that the absentees were considered present before the court for purposes of the Necessary Party Rule, ${ }^{97}$ (2) absentees could not proceed at law after a suit had been commenced in equity; (3) claimants who appeared before the master received the benefit of the decree, ${ }^{98}(4)$ the administrator of the debtor's or decedent's estate would be protected from suits by absentees, in effect being treated as a legally immune conduit; and (5) after the final decree, an omitted creditor was not barred from filing his own bill against distributees, but he would be subject to the defense of laches.

A variation of the creditors' bill also made an appearance in the mideighteenth century. These were suits by a ship crew to recover prize money from the owner or master of the vessel, wherein one or more but less than all of the crew members brought the bill. In these cases, the first cycle of doctrine, as in the creditors' bill cases, involved the necessary parties problem-whether the plaintiffs could proceed without joinder of the whole

96 Id. at 208-11, 39 Eng. Rep. at 660-61. The court's reference to the practical inefficacy of advertisements to apprise absentees of the pending proceeding is remarkably similar to Justice Jackson's observations on the same subject in Mullane v. Central Hanover Bank \&: Trust Co:

It would be idle to pretend that publication alone, as prescribed here, is a reliable means of acquainting interested parties of the fact that their rights are before the courts .... Chance alone brings to the attention of even a local resident an advertisement in small type inserted in the back pages of a newspaper....

339 U.S. 306, 315 (1950).

${ }^{97}$ In modern procedural parlance, we would say that the court had worked out the idea of a conditionally necessary party. That is, all the creditors or legatees were necessary parties and should have been brought into the suit if doing so was feasible. Notice by advertisement was given to this end. The presence of the nonappearing claimants, however, was not "indispensable." It was regarded as more expedient to proceed without the absentees than to refuse to proceed on account of their absence. See FED. R. CIV. P. 19. See also, e.g., Frovident Tradesmens Bank \& Trust Co. v. Patterson, 390 U.S. 102, 125 (1968) ("Rule 19(b) . . is . . . a valid statement of the criteria for determining whether to proceed or dismiss in the . . . absence of an interested person."). The risk that an absent claimant would later bring suit against the distributees was rightly regarded as remote. Because the absentee could not be bound by the decree, however, that risk was also unavoidable.

${ }^{98}$ In modern procedural parlance, we would say that the absentees coming in after initial decree had the benefit of one way intervention, see Union Carbide \& Carbon Corp. v. Nisley, 300 F.2d 561, 569 (10th Cir. 1961), or offensive issue preclusion, see Parklane Hosiery Co. v. Shore, 439 U.S. 322, 331-33 (1979) ("[T] he preferable approach . . . in the federal courts is not to preclude the use of offensive collateral estoppel, but to grant trial courts broad discretion to determine when it should be applied."). 
crew. In Leigh $v$. Thomas, ${ }^{99}$ two seamen sought an accounting of prize money in behalf of sixty-four of a total crew of eighty, pursuant to a written power of attorney. The procedural problem apparently arose from the plaintiffs' lack of express authority from the rest of their fellow crew members. This harkens to Brown v. Vermuden, ${ }^{100}$ in which some of the miners had represented the whole group. Like Brown v. Vermuden, the ship crew's situation can be considered an association type of case rather than a creditors' bill. Not only did the crew have a preexisting group relationship, but that relationship was the basis of the legal obligation that commonly affected them. In any event, the court in Leigh $v$. Thomas sustained a demurrer for failure to have brought the suit in behalf of the entire crew. ${ }^{101}$ The court reasoned that the suit must be in behalf of all the crew, because to hold otherwise, the owners would have to account to the nonsignatory members in separate bills and thereby would be subjected to a multiplicity of suits. ${ }^{102}$

In Good v. Blewitt, ${ }^{103}$ the Master of the Rolls sustained a bill in behalf of all crew members, holding that the rule requiring joinder of all necessary parties would be excused where there was a large number of potential plaintiffs, some being geographically dispersed, some dead, and some whose identity could not be ascertained. In response to an objection that the owners would face a multiplicity of suits and possible multiple liability, the court held that the defendants would receive the same protection as an executor in a legatee suit. Presumably, this meant that a payment by the defendant in compliance with the decree would exonerate the defendant from further obligation, though it might leave an unjoined claimant free to pursue the distributees to get redress for unjust enrichment.

The question of the absent claimants' rights arose in another ship crew case, Pearson $v$. Belchier. ${ }^{104}$ A bill for an account of prize money had culminated in a final decree in 1752. In 1781, several seamen who had neither appeared in that proceeding nor been included in the distribution, filed a bill

992 Ves. Sen. 312, 312, 28 Eng. Rep. 201, 201 (Ch. 1751) (sustaining a demurrer for failure to include all parties in a suit).

${ }^{100} 1$ Chan. Cas. 272, 272, 22 Eng. Rep. 796, 797 (Ch. 1676) ("Four Persons were named by the Miners to defend the suit for them ....").

1012 Ves. Sen. 312, 28 Eng. Rep. 201 (Ch. 1751).

102 See id. at 313, Eng. Rep. at 201 ("TT]here is no instance of a bill by three or four to have an account of the estate, without saying they bring it in behalf of themselves and the rest of the creditors: otherwise the executor may account to all the other creditors in other bills.").

${ }^{103} 13$ Ves. Jun. 397, 33 Eng. Rep. 343 (Ch. 1807). But see Moffatt v. Farquharson, 2 Bro. C.C. 338, 338, 29 Eng. Rep. 189, 189 (M.R. 1788) (holding that all part-owners of a ship must be joined as plaintiffs). The reporter of the decision observes in a note following the case that "[t]he decision here is clearly wrong . . . and has been over-ruled repeatedly." Id. (emphasis omitted).

${ }^{104} 4$ Ves. Jun. 627, 31 Eng. Rep. 323 (Ch. 1799). 
to revive the original decree. The court held that the plaintiffs were precluded from suit against the owners, who had distributed the prize money pursuant to the decree. ${ }^{105}$ The ground of decision was that a presumption of payment arose from the lapse of time between the prior decree and the present suit to collect. ${ }^{106}$ Preclusion in that case, similar to the absent legatee and creditor cases discussed earlier, was based again on laches and not res judicata through representation.

\section{Unincorporated Associations}

The third line of cases involved suits by and against members of unincorporated associations. One of the earliest cases of this type, City of London v. Richmond, ${ }^{107}$ presented the necessary parties problem. The city filed a bill for breach of a water lease contract against a few of the numerous shareholders in the venture, but not the promoter or the original lessee. The court held that the number of potential defendants was so great as to make their joinder impracticable, and that joinder of the absentees was therefore excused. $^{108}$

In 1722, the court in Chancey $v . M a y,{ }^{109}$ applied the same principle to joinder of numerous plaintiffs in a suit for an accounting in behalf of all partners of a large partnership. The court held that the defendants would not be subject to multiple suits because "all the rest [of the absent partners] were in effect parties." 110 That proposition overcame the necessary party's objection and may also have indicated that the absent partners, if they wished to maintain the litigation, would be compelled to become parties to the instant case rather than proceed separately, a principle which, as we have seen, came to be applied in the creditors' bill cases. These decisions, however, left open the question whether the absentees would be precluded by the decree.

In 1781, a suit was allowed against the members of the executive committee of a voluntary association on their personal undertaking in behalf of the association, without requiring joinder of all the association's mem-

${ }^{105}$ See id. at 629-30, 31 Eng. Rep. at 324 ("Length of time cannot be pleaded in bar[] ... therefore the bill must be dismissed.").

${ }_{106}$ See id. at 629, 31 Eng. Rep. at 324 ("Defendants ... relied on the length of time, as affording a presumption of satisfaction.").

${ }^{107} 2$ Vern. 421, 23 Eng. Rep. 870 (Ch. 1701).

${ }^{108}$ See id. at 422, 23 Eng. Rep. at 871 ("[T] he assignees by dividing of it into so many shares, had made it impracticable to have them all before the court.").

${ }^{109}$ Prec. Ch. 592, 24 Eng. Rep. 265 (Ch. 1722).

110 Id. at 592, 24 Eng. Rep. at 265. 
bers. ${ }^{111}$ In another case decided two decades later, members of a voluntary association of freemasons were allowed to proceed as plaintiffs by representative suit to quiet possession of books and uniforms of their lodge. ${ }^{112}$

In the early nineteenth century, two other cases moved toward generalizing the concept of a representative suit in "association" situations. In Adair v. New River Co., ${ }^{113}$ a shareholder in an annuity arrangement filed a bill for an accounting against several of a large number of other shareholders. The defendants' objection that the other shareholders were necessary parties was overruled. In its decision, the court adverted to the proposition, expressed in the creditors' bills cases, that in representative suits the absentees are "in a sense before the Court,"114 but principal reliance was placed on comparison to the bill of peace:

[A]nd it is not necessary to bring all the individuals: why? Not, that it is inexpedient, but, that it is impracticable, to bring them all. The Court therefore has required so many, that it can be justly said, they will fairly and honestly try the legal right between themselves, all other persons interested, and the Plaintiff; and, when the legal right is so established at law, the remedy in equity is very simple: merely a bill; stating, that the right has been established in such a proceeding; and upon that ground a Court of Equity will give the Plaintiff relief against the Defendants in the second suit, only represented by those in the first. I feel a strong inclination, that a decree of the same nature may be made in this case. $^{115}$

The case actually deals only with the necessary parties problem; the statements about the effect of the decree on absent shareholders are dicta.

The second case, Cockburn v. Thompson, ${ }^{116}$ was a bill for an accounting and dissolution of an annuity company. The suit was brought by several of the company's proprietors in behalf of all of the proprietors, against the solicitor and bankers of the company. In holding that the suit could be maintained in this representative fashion, the court undertook a lengthy review of many representative suit cases, struggling with limited success to put them in coherent order. The court concluded that the responsible officers or managers of an unincorporated association could be taken as representing the members of the association for purposes of litigation concerning its af-

111 See Cullen v. Queensberry, I Bro. C.C. 101, 101, 28 Eng. Rep. 1011, 1011 (Ch. 1781) (holding it is "not necessary to include all the subscribers" when suing a voluntary society).

112 See Lloyd v. Loaring, 6 Ves. Jun. 773, 778-79, 31 Eng. Rep. 1302, 1304-05 (Ch. 1802) (allowing the plaintiffs to amend suit to sue as individuals with a joint interest in property because the voluntary society "must some way or other be permitted to sue").

11311 Ves. Jun. 429, 32 Eng. Rep. 1153 (Ch. 1805).

${ }^{114}$ Id. at 444, 32 Eng. Rep. at 1159.

115 Id.

11616 Ves. Jun. 321, 33 Eng. Rep. 1005 (Ch. 1809). 
fairs. ${ }^{117}$ After Cockburn, this line of doctrine was extended during the next couple of decades into a fairly firm line of precedent under which unincorporated associations, if not other groups, could sue or be sued by the mechanism of the representative suit. ${ }^{18}$

\section{Summary of English Law to 1830}

Few English cases from the middle of the seventeenth century to the beginning of the nineteenth century deal squarely with the effect of a decree upon absent numerous parties whose joinder has been excused on the basis of representation. In the bill of peace cases involving claims for land rents against some, but less than all, of the obligors, absent parties seem not to have been bound at all. The defendant's objection in such cases was that he was being singled out for imposition of the rent charges when others were also liable. In response to this objection, it was said that he could receive contribution from the absentees. This analysis is alien to a theory of representation, however, in that it pits the class representative against the absent class members. Assuming that the defendants could pursue such contribution, that proposition does not imply the decree would be binding in their favor against those from whom contribution was subsequently sought. It also does not imply that the plaintiff could use the decree as a foundation for imposing liability on the absentees. Of the bill of peace cases, only Brown v. Vermuden ${ }^{119}$ and Brown v. Booth ${ }^{120}$ provide a rationale for binding absent

${ }^{117}$ See id. at 329-30, 32 Eng. Rep. at 1008 ("Though the Plaintiffs cannot bring forward all the persons, who may be liable upon the result of the account, that is not an obstacle, that should prevent the institution of this suit, if necessary to justice.").

${ }^{118}$ See, e.g., Fenn v. Craig, 3 Y. \& C. Ex. 216, 221-24, 160 Eng. Rep. 680, $682-83$ (Ex. 1838) (allowing suit against the trustees of a company in behalf of all trustees and shareholders); Small v. Attwood, You. 407, 457-61, 159 Eng. Rep. 1051, 1072-73 (Ex. 1832) (allowing a bill to rescind a contract to be filed by some partners within a company in behalf of all partners); Newton v. Egmont, 5 Sim. 130, 137-38, 58 Eng. Rep. 286, 289 (V.C. 1832) (allowing a plaintiff to amend suit to include all creditors); Hichens v. Congreve, 4 Russ. 562, 575-77, 38 Eng. Rep. 917, 922-23 (Ch. 1828) (allowing suit by shareholders in behalf of themselves and other shareholders); Ellison v. Bignold, 2 Jac. \& W. 503, 510-12, 37 Eng. Rep. 720, 722-23 (Ch. 1821) (allowing suit by some directors of a voluntary society in behalf of themselves and all members); Meux v. Maltby, 2 Swans. 277, 286-87, 36 Eng. Rep. 621, 624-25 (Ch. 1818) (allowing suit against the treasurer as the representative of a joint stock company); Beaumont v. Meredith, 3 V. \& B. 180, 182, 35 Eng. Rep. 447,448 (Ch. 1814) (allowing the plaintiffs to sue in behalf of themselves and all other members of a particular Society). But see Long v. Yonge, 2 Sim. 369, 385-87, 57 Eng. Rep. 827, 833-34 (V.C. 1830) (disallowing some members of a partnership, in behalf of themselves and others, to file a bill for dissolution of the partnership because such a bill would deprive too many nonparties of their rights).

1191 Chan. Cas. 271, 22 Eng. Rep. 796 (Ch. 1676).

${ }^{120} 2$ Vern. 184, 23 Eng. Rep. 720 (Ch. 1690). 
parties, and in those cases the absentees may be taken to have authorized the representation by the parties actually joined. ${ }^{121}$

The creditor bill cases developed the concept of representation more fully. When the problem of precluding absentees was directly confronted in the Gillespie ${ }^{122}$ and David ${ }^{123}$ cases, it was held that absentees were not bound by the decree. In the prize cases and the voluntary association cases, there are dicta about binding absent parties, but no case has been found with a square holding on the issue.

The preclusive effect of a representative suit in English Chancery practice thus stood unsettled in the early nineteenth century. If any principles could be distilled from the English precedents as of about 1830, they were as follows:

Where many claimants or obligors are involved:

(a) The Necessary Parties Rule will be relaxed so that the suit may go forward by having some members represent the whole group. Questions of the rights and duties of absentees are to be left to subsequent litigation, if such litigation should actually eventuate.

(b) The absentees are affected by the decree as follows:

(1) The absentees are bound if the representatives appearing as parties were expressly or impliedly authorized by the absentees to sue or defend in their behalf. In litigation arising from activities of a preexisting group, such as an association, such authority impliedly reposes in the members of the group who present themselves as parties.

(2) Where one of several similarly situated claimants has been authorized by the court to sue to recover assets to pay claims, all known claimants are entitled to share in the recovery and are limited to that remedy. Other claimants are relegated to whatever remedies at law they may have against the obligor subject to the statutes of limitation. ${ }^{124}$

This scheme obviously amounted to relatively little in the way of res judicata doctrine. It achieved nominal compliance with the Necessary Parties Rule by treating the absentees as if they were parties for purposes of joinder of parties. It obligated a creditor class to share proceeds realized

${ }^{121}$ See discussion supra Part I.B.1.

1223 Russ. 130, 38 Eng. Rep. 525 (Ch. 1827).

${ }^{123} 1$ My. \& K. 200, 39 Eng. Rep. 657 (Ch. 1833).

${ }^{124}$ The only case that appears to contradict this formulation is City of London $v$. Perkins, 3 Bro. P.C. 602, 1 Eng. Rep. 1524 (H.L. 1734), discussed at supra note 65 and accompanying text. That case may simply be a sport in the law. Certainly it is difficult to fit within the law of the time, but it may be an application of the doctrine of stare decisis. See Yeazell, From Group Litigation, supra note 12, at 539-44 (tracing cases of stare decisis involving group litigation). 
from the debtor, which simply gives effect to the maxim that he who seeks equity must do equity. Beyond that, it made the decree binding only on those absentees who had, prior to the litigation, some connection with the representative concerning the matter in litigation.

\section{AMERICAN DOCTRINE BEFORE 1853}

\section{A. Justice Story's Treatise}

Justice Joseph Story's Commentaries on Equity Pleadings, ${ }^{125}$ in a clear but indirect way, virtually created the American law of class suits. Story considered the representative suit, not as a principal subject, but as an exception to the rule governing joinder of necessary parties. His thoughts about representative suits were incompletely formed, tentative, and ambivalent. Nevertheless, he devised a classification of class suits that has descended into modern times. Story's concepts became the basis of Professor J.W. Moore's treatment of class suits in the Federal Rules of Civil Procedure of $1938^{126}$ and are still embedded in Rule 23 as amended in $1966 .{ }^{127}$

That Story approached the class suit as an exception to the Necessary Parties Rule appears from the fact that he dealt with the problem under the heading of "Proper Parties to Bills.","28 Under that heading, Story stated the general rule that "all persons materially interested in the subject-matter [of the suit] ought to be [joined]," 129 with exceptions that joinder will be excused in situations in which it is impracticable, ${ }^{130}$ and when "as to parties... where they are exceedingly numerous, and it would be impracticable to join them without almost interminable delays and other

${ }^{125}$ STORY, supra note 74.

126 See James Wm. Moore \& Marcus Cohn, Federal Class Actions, 32 ILL. L. REV. 307, 308, 310-11 n.25 (1937) [hereinafter Moore \& Cohn, Federal Class Actions] ("And in large measure Story's analysis has been the basis for the federal rule."); James Wm. Moore, Federal Rules of Civil Procedure: Some Problems Raised by the Preliminary Draft, 25 GEO. L.J. 551, 570-76 (1937) (explaining class action suits as exceptions to the Necessary Parties Rule).

127 See Benjamin Kaplan, Continuing Work of the Civil Committee: 1966 Amendments of the Federal Rules of Civil Procedure (I), 81 HARv. L. REv. 356, 376-94, 377 n.72 (1967) (explaining Moore's view as derivative of Story's, and further expounding on Moore's treatment of class suits).

${ }^{128}$ STORY, supra note $74, \S \S 72-238$, at 74 .

129 Id. $\$ 76 . \mathrm{a}$, at 77.

130 See id. $\S 78$, at $79-80$ (describing situations where joinder is excused due to impracticability). Illustrations of the "impracticability" exception are given in the immediately following sections as follows: "party in interest" out of the jurisdiction, see id. $\S 80$, at $80-81$; suit involving a decedent's estate and in which the personal representative has not been constituted, see id. $\S 91$, at 91 ; and proper or necessary parties unknown to plaintiff, see id. $\S 92$, at 92. 
inconveniences.... In such cases, the Court... will dispense with them ... if it can be done without injury to the persons not actually before the Court."131

But Story then made exceptions to the exceptions:

And even in the cases, in which the Court will thus administer relief [i.e., where the court proceeds in the absence of "interested" persons to decide the case before it], so solicitous is [the Court] to attain the purposes of substantial justice, that it will generally require the Bill to be filed, not only in behalf of the plaintiff, but also in behalf of all other persons interested, who are not directly made parties (although in a sense they are thus made so), so that they may come in under the decree, and take the benefit of it, or show it to be erroneous, or entitle themselves to a rehearing. The Court will go further, and in such cases, it will entertain a Bill or Petition, which shall bring the rights and interests of the absent parties more distinctly before the Court, if there is any certainty, or even any danger of injury or injustice to them.

Story found the cases excusing joinder of numerous parties to be in three categories: where the question is of "common or general" interest, where a voluntary association is involved, and where the parties are so numerous that, without regard to any other criterion, it is impracticable to join them. ${ }^{133}$ In the first category, that of cases involving a question of "common or general" interest, Story included the creditor, legatee bill, and prize cases. ${ }^{134}$

With respect to the second category, voluntary associations, Story stated:

[T]hose, who sue or defend, may fairly be presumed to represent the rights and interests of the whole.... [T] he persons interested are commonly numerous.... [A]s there is a privity of interest, the Court will allow a Bill to be brought by some of the parties on behalf of themselves and all the others Bs

Story did not define the term "privity." The absentees in the cases to which he referred, however, had some kind of associational tie that existed before the commencement of the litigation, and this seems to have been to what he was referring. ${ }^{136}$

13! Id. $\$ 94$, at $93-94$.

132 Id. \$ 96, at $95-97$ (footnotes omitted).

133 See id. $\$ 97$, at $97-98$ (listing these three types of cases in which the courts have excused the joinder of parties).

134 See id. $\$ \S 98-106$, at $98-112$ (discussing the reasons why the courts have excused nonjoinder in the creditor, legatee bill, and prize cases).

${ }^{135}$ Id. $\$ 107$, at 113 (footnote omitted).

${ }^{136}$ See id. $\S \S 108-19$, at 113-20 (discussing absent persons of interest and how they must be related to parties at suit). Sections 108-19 of Story's work dealt with partnerships, joint 
Later in his discussion, after a description of bill of peace cases, Story returned to "association" cases. ${ }^{137}$ His discussion at this point concerned decisions in which some members were not allowed to proceed in the absence of the rest. ${ }^{138} \mathrm{He}$ struggled for a rationale to explain these decisions, which of course contradicted the general principles he previously had expounded. Citing Beaumont v. Meredith, ${ }^{139}$ for example, Story stated that a suit to dissolve a voluntary association cannot be maintained by representatives because all members had an "equal interest to be heard." Story then suggested that the representative suit may not be used when the absentees "have a substantial interest in the very question of right, on which the decree must hinge."141 In making this suggestion, Story cited cases in which conflict of interest within the group precluded a representative suit, particularly conflict of priority among classes of creditors. ${ }^{142}$ Story seems thus to have realized that the tie of membership in an association might be an insufficient basis for permitting some members of a group to represent all members where the litigation concerns intra-association conflicts. Hence, Story may have perceived but not quite articulated the point that there could be a conflict of interest among members of a class, even a tightly-knit association. There could be such conflict, for example, between members who are in favor of and those who are opposed to dissolution of the association. ${ }^{143}$

Story's third category of permissible representative suits is peculiar. As Story described those cases, the defining characteristic was that they involved numerous persons. Numerousness, however, was also a characteris-

stock companies, churches, social clubs, and annuity funds. Story explains some of the cases on the basis that the suit is for a "common benefit." Id. $\S 115 . a$, at 118. Other cases are explained on the basis that the suit is "against some, being proprietors," id. $\$ 111$, at 115 , or that the defendants "may be considered as representing the company," id. $\$ 117$, at 118 (quoting Meux v. Maltby, 2 Swans. 277, 284, 36 Eng. Rep. 621, 624 (Ch. 1818)). Story uses the terms "common interest," Story, supra note 74 , at $\$ \S 112-13,115-16$; "interests . . of a common character," id. $\S 116$, at 118 ; and "common right," id. $\S 109$, at 114 . An annuity association case is analyzed as one where a representative suit "virtually brought" absentees before the court. Id. $\$ 110$, at 114 .

${ }^{137}$ See Story, supra note $74, \S \S 127-34$, at $126-33$ (describing cases in which suits were allowed to continue despite the fact that not all members of a group were parties, as well as cases in which the lack of all parties meant dismissal).

${ }^{138}$ See id. $\$ \S 130-34$, at 129-33 (discussing "association" cases in which the courts decided that all members must be made parties to sustain the action).

${ }_{139} 3$ V. \& B. 180, 180, 35 Eng. Rep. 447,447 (Ch. 1814) (holding that all members of an "account" must be parties to a suit alleging wrongful dissolution against the trustees).

${ }^{140}$ STORY, supra note $74, \S 131$, at 129.

${ }^{141}$ Id. $\S 132$, at 130 .

142 See id. $\S 133$, at 132 (discussing the class of cases in which all creditors must be made parties because the court's decision could affect the rights of missing parties).

143 Story observed that "[t]here is not a little difficulty in this whole doctrine." Id. $\$ 131$, at $130 \mathrm{n} .1$. That statement of course remains very true. 
tic of the classes in his first two categories. His problem, therefore, is to deduce the additional characteristic of the members of this third type of class beyond their being numerous. Story stated:

[T] here is usually a privity of interest between the parties; but such a privity is not the foundation of the exception. On the contrary, it is sustained in some cases, where no such privity exists. However, in all of them there always exists a common interest or a common right ... or a general claim or privilege, which [the bill] seeks to establish, or to narrow, or take away.

The cases that Story put in this category are what have been previously described as the bill of peace cases, including the "manorial" cases and the tithe cases like Brown v. Vermuden. ${ }^{145}$ Story concluded that even though there may be no "privity" between the representative and the absentees, the suit may proceed where there is either a "general right" claimed by the plaintiff, ${ }^{146}$ or where the right claimed "affected the defendants and all others in the same way." $" 147$

At least some of the cases to which Story was referring concerned res judicata-the binding effect on absentees-as distinct from the problem of joinder under the Necessary Parties Rule. Story stated, "[i]ndeed, in most, if not in all, cases of this sort, the decree obtained upon such a Bill will ordinarily be held binding upon all other persons standing in the same predicament ...." "148

Thus, Story's treatment of the binding effect of a class suit decree is tentative and indeed puzzling. His analytical system consists of categories that overlap, or, in terminology now fashionable, are "overinclusive." As noted above, cases involving "associations" (his second category) also involve questions of "common or general interest" (his first category), and typically involve "parties too numerous" to be joined (his third category). Questions of "common or general interest" (his first category) often involve "parties too numerous" (his third category). Furthermore, "parties too numerous" can be distinguished from mankind at large only by reference to some kind of interest or question that is "common or general" to them but not to others. In any event, Story clearly did not assert that, within his system of classification, the type of suit determined the res judicata effects of

144 Id. $\S 120$, at 120 (footnote omitted).

1451 Chan. Cas. 272, 22 Eng. Rep. 796 (Ch. 1676).

146 STORY, supra note 74, $\$ 124$, at 123 ("But Bills have also been allowed to be brought [called bills of peace] where there has been a general right claimed ... yet no privity existed ....").

147 Id. $\S 124$, at 124 .

${ }^{148}$ Id. $\S 120$, at 120 . Story illustrated this quotation with the example of a miller possessing a monopoly that requires all inhabitants of a district to use his mill. The miller may sue a few inhabitants to establish his rights against all inhabitants. See id. $\S 123$, at 123. 
the judgment. The best he could make of the precedents was that judgments involving members of associations were sometimes binding on absentees, and that the same was true of creditors' bills and bills of peace.

It is appropriate to step back from procedural doctrine and for a moment take note of the substance of the social conflicts that these representative suits were trying to address. These included disputes over inheritance (the legatees' bills), between debtor and creditor and among creditors unsatisfied in their just debts (the creditors' bills), the governance of private business and eleemosynary associations (the "association" cases), and the legitimacy of measures taken by local government (the tithe and manorial cases). These social conflicts are, in human affairs, perennial and fundamental conflicts made more complicated because they involve not two sides, but three or more sides. The ex-ante question is whether all members of a group should be regarded as participating in litigation. The ex-post question is whether all members will subsequently be required to hold their peace. Yet, any member of any group would have to wonder what he was getting into ex-ante. A member would also wonder why he should later be precluded from asserting his rights for simply having remained a passive bystander to another's litigation. He would wonder, in short, why it was not right to have stayed out of litigation over inheritance, bad debts, mismanagement of enterprises, and squabbles in local government, and to pursue his rights by litigation only if it later seemed worthwhile to do so.

\section{B. Federal Decisions Before Smith v. Swormstedt}

There are few federal cases dealing with any aspect of representative suits from 1789 , when the federal court system was created, until 1853, when Smith v. Swormstedt ${ }^{149}$ was decided. Of the handful of cases, all dealt with class suits in the context of the necessary parties problem. That problem was especially acute in federal law because federal jurisdiction at the time was primarily diversity jurisdiction, and it had been held earlier that diversity must be "complete": all properly joined plaintiffs must be diverse in their citizenship from all properly joined defendants. ${ }^{150}$ The representa-

14957 U.S. 288, 16 How. 307 (1853) (involving a situation in which a few individuals represented a larger class's interest).

${ }^{150}$ See Strawbridge v. Curtiss, 7 U.S. 267, 3 Cranch 159 (1806) (holding that federal jurisdiction could not be supported where all plaintiffs and all but one defendant were citizens of the same state). The classic formulation of the Necessary Parties Rule in federal practice is in Elmendorf v. Taylor, 23 U.S. 152, 10 Wheat. 67 (1825). In Elmendorf, one of several tenants in common brought an action to compel conveyance of the property. The respondents objected to the failure to join the plaintiff's co-tenants, which would have been impossible 
tive suit, where only the citizenship of the representative counted in determining party citizenship, was an avenue of escape from the "complete diversity" requirement. Hence, in the context of joinder of parties in diversity litigation, the representative suit had considerable doctrinal significance and appeal. But no representative suit cases in that period squarely dealt with the preclusive effect on absentees of a judgment in such a case.

Most of the cases involved creditors' bills. The earliest appears to be Joy v. Wirtz, ${ }^{151}$ in which the Circuit Court said:

Where the creditors are to be paid out of a particular fund, or are united in the same transaction, so as to produce a privity between them, all are to join.... The object of this bill, is to set aside this release .... The court cannot set it aside... unless all were parties, either by name, or as being represented by a part, suing in the names of all. ${ }^{152}$

In another creditors' bill case, which reached the Supreme Court, Chief Justice Marshall said:

under the "complete diversity" rule. The Court stated that the rule requiring all equitable parties to be brought before the court

is not, like the description of parties, an inflexible rule, a failure to observe which turns the party out of court, because it has no jurisdiction over his cause; but being introduced by the court itself, for the purposes of justice, is susceptible of modification, for the promotion of those purposes.

Id. at 165,10 Wheat. at 80 . A remarkable number of early cases involved this conjunction of the Necessary Parties Rule and the complete diversity requirement. See Mallow v. Hinde, 25 U.S. 193, 12 Wheat. 123 (1827) (discussing the flexibility needed in the federal courts when deciding who are necessary parties so as not to sacrifice jurisdiction); Harding v. Handy, 24 U.S. 103, 11 Wheat. 46 (1826) (involving an objection to missing parties who were heirs to an estate but who might have destroyed diversity jurisdiction); Wormley v. Wormley, 21 U.S. 421, 8 Wheat. 186 (1823) (stating that rather than sacrifice jurisdiction, the court will proceed without the missing parties if possible); Kerr v. Watts, 19 U.S. 550, 6 Wheat. 246 (1821) (stating that "[n]o one need be made a party complainant in whom there exists no interest, and no one party defendant from whom nothing is demanded"); Marshall v. Beverley, 18 U.S. 313,5 Wheat. 42 (1820) (standing for the proposition that an injunction could not be issued until all parties in interest are brought before the court); Simms v. Guthrie, 13 U.S. 18, 9 Cranch 144 (1815) (dismissing an objection to lack of proper parties where the inclusion of the missing parties would destroy diversity jurisdiction and the suit was not an original bill, but was based on a judgment rendered in federal court and so required to be brought there); Milligan v. Milledge, 7 U.S. 220, 3 Cranch 133 (1805) (holding that the lack of all necessary parties is not a valid plea if those missing parties are not within the court's jurisdiction); $c f$. Mandeville v. Riggs, 27 U.S. 482, 2 Pet. 311 (1829) (stating that all parties liable for contribution should be included but admitting that there may be exceptions, such as when the party would destroy jurisdiction and is not indispensable).

15113 F. Cas. 1172 (C.C.D. Pa. 1806) (No. 7553); Russell v. Clark's Executors, 11 U.S. $69,98,7$ Cranch 44, 62 (1812) (finding error in the lower court's recovery of "sundry bills of exchange," since "the assignees ... are so essential to the merits of the question, and may be so much affected by the decree, that the Court cannot proceed to a final decision of the cause till they are parties").

${ }^{152}$ Wirtz, 13 F. Cas. at 1172 . 
It is true, that the creditors might have been made parties defendants, but we do not think them parties who may not be dispensed with. So much of the fund as yet remains may be brought into Court and may be distributed according to the rights of those who may apply for it. 153

Justice Story himself had a couple of related cases on circuit. One of them, West $v$. Randall, ${ }^{154}$ was a suit for an accounting brought by one of several legatees against an executor. Story reviewed the entire English law of representative suits in disposing of an objection of lack of necessary parties, that is, the other legatees. Observing that there were exceptions to the necessary party doctrine, he said:

Nor are these the only cases; for where the parties are very numerous, and the court perceives, that it will be almost impossible to bring them all before the court; or where the question is of general interest, and a few may sue for the benefit of the whole; or where the parties form a part of a voluntary association for public or private purposes, and may be fairly supposed to represent the rights and interests of the whole; in these and analogous cases, if the bill purports to be not merely in behalf of the plaintiffs, but of all others interested, the plea of the want of parties will be repelled .... Yet, in these cases, so solicitous is the court to attain substantial justice, that it will permit the other parties to come in under the decree, and take the benefit of it, or to show it to be erroneous, and award a re-hearing; or will entertain a bill or petition, which shall bring the rights of such parties more distinctly before the court ....

The second of Story's cases on circuit was Wood v. Dummer, ${ }^{156}$ decided in 1824. This litigation presented Story with a peculiar variant of the necessary parties problem. A bank had issued a promissory note and later ceased doing business. The present suit was brought on the note against several of the bank's shareholders. The plaintiff's theory was that the defendant shareholders had been paid dividends in violation of statute, thus wrongfully causing the bank's insolvency, and ought personally to restore the deficiency of assets. Defendants objected that all shareholders were necessary party defendants. Story, relying on West $v$. Randall, said:

In respect to the exception [to the Necessary Party Rule] on account of the numerousness of parties, the question has been ... acted upon in many cases ... . The result . . . is, that where the parties are so numerous, that it is inconvenient or impracticable to bring all before the court, the rule... shall not be applied ....

153 Potter v. Gardner, 25 U.S. 498, 501, 12 Wheat. 317, 319 (1827).

15429 F. Cas. 718 (C.C.D.R.I. 1820) (No. 17,424).

${ }^{155}$ Id. at 722 . Story added that the represented absentees were "quasi parties." Id. at 723.

15630 F. Cas. 435 (C.C.D. Me. 1824) (No. 17,944).

157 Id. at 439 (citations omitted). 


\section{He added:}

Now, no case could afford a stronger illustration for the application of the principle .... There is no complaint, that the defendants now before the court do not represent effectually the interests adverse to the plaintiffs, or ... that the other stockholders have means of affording a more effectual defence to the defendants in respect to their own particular interests. ${ }^{158}$

Story concluded that the plaintiff could recover from the named defendants only a pro rata allocation of the loss. This plainly makes the case one of excusing nonjoinder of absentees while not binding them to the decree.

Apparently, the only other federal case involving a representative suit prior to Smith v. Swormstedt ${ }^{159}$ was an "association" case in 1829 , Beatty $v$. Kurtz. ${ }^{160}$ In Beatty, several parishioners of the German Lutheran Church in Georgetown (part of the District of Columbia) filed suit in behalf of themselves and all parishioners to be quieted in possession against a person who was interfering with property used as a cemetery. Story held there was no necessary parties problem because "we think it one of those cases, in which certain persons, belonging to a voluntary society ... may sue in behalf of themselves and others having the like interest, as part of the same society, for purposes common to all, and beneficial to all."161

These developments are consistent with the formulation we have tendered of class suit doctrine as it was received from English law. ${ }^{162}$ That is, there was still no "rule" of res judicata in class suits.

\section{Developments in the State Courts ${ }^{163}$}

\section{New York Decisions}

The state court cases decided in the first half of the nineteenth century reflect essentially the pattern described above. Again, the salient problem was joinder of parties, ${ }^{164}$ particularly as it arose in creditor and legatee

$158 \mathrm{Id}$.

15957 U.S. 288, 16 How. 307 (1853).

${ }^{160} 27$ U.S. 565, 2 Pet. 362 (1829).

161 Id. at 585,2 Pet. at 374.

162 See supra note 124 and accompanying text (discussing English case law that establishes the exception to requiring joinder of all necessary parties).

${ }^{163}$ The focus in this section is upon cases in New York, which was the first state to deal extensively with representative suits.

${ }^{164}$ See, e.g., Wiser v. Blachly, 1 Johns. Ch. 437, 438 (N.Y. Ch. 1815) ("[Y]ou must have before the court all parties whose interests the decree may touch .... But the general rule is not of universal application .... [C]ases have created ... exceptions to the general rule."). 
bills. $^{165}$ The representative character of these proceedings, in addition to satisfying the imperative of the Necessary Parties Rule, was said to protect the administrator or executor from defending numerous suits; ${ }^{166}$ to preserve the fund from depletion by the expense of defending numerous suits; ${ }^{167}$ to ensure equality of treatment among creditors; ${ }^{168}$ to prevent inconsistent results; ${ }^{169}$ and to protect or effectuate equity jurisdiction. ${ }^{170}$ The pleading rule evolved that representative suits had to be brought "on behalf of" interested parties, so that absentees could "come in under the decree." The required similarity of interest between representative and absentee was also articulated. A secured creditor, for example, could not represent general creditors, ${ }^{172}$ and a residuary legatee could not represent specific legatees or legatees otherwise in a different class. ${ }^{173}$

Regarding the binding effect of a decree, hesitation and uncertainty continued:

[E]quity is satisfied with having so many parties before it as may be supposed to represent the claim fairly, to contest it honestly in behalf of the whole, and therefore in a sense to bind it.... Of course the principle always presupposes

${ }^{165}$ See, e.g., Ross v. Crary, 1 Paige Ch. 416,417 (N.Y. Ch. 1829) (directing an accounting in one legatee suit to be conclusive for all who came in under that decree while staying proceedings in other suits or the same cause of action); Brown v. Ricketts, 3 Johns. Ch. 553, 555-56 (N.Y. Ch. 1818) (holding that bills by creditors and nonresiduary legatees are exceptions to the general rule requiring all parties); Hendricks v. Robinson, 2 Johns. Ch. 283, 29697 (N.Y. Ch. 1817) (declining to dismiss a creditor's bill upon demurrer for failure to join other judgment creditors).

${ }^{166}$ See Fish v. Howland, 1 Paige Ch. 20, 23 (N.Y. Ch. 1828) (stating that when parties are able to come in under a decree yet neglect to do so, "the court will not subject the defendants to the expense of relitigating ... in another action").

${ }^{167}$ See Ross, 1 Paige Ch. at 417-18 (stating that when the fund is insufficient to pay all the claims against it, the court will stay all but one proceeding and direct an accounting in that one case).

${ }^{168}$ See Egberts v. Wood, 3 Paige Ch. 517 (N.Y. Ch. 1832) (stating that a representative suit was necessary and proper to "enforc[e] the principle of equity among creditors").

${ }^{169}$ See Kettle v. Crary, 1 Paige Ch. 417 (N.Y. Ch. n.d.). This unreported case is reprinted in full in a footnote to Ross v. Crary, 1 Paige Ch. at 417 note a.

${ }^{170}$ See Thompson v. Brown, 4 Johns. Ch. 619, 643-45 (N.Y. Ch. 1820) (stating that the fidelity of a decree approving a distribution was necessary to preserve chancery jurisdiction).

171 Brown v. Ricketts, 3 Johns. Ch. 553, 555 (N.Y. Ch. 1818).

172 See Palmer v. Foote, 7 Paige Ch. 437,438 (N.Y. Ch. 1839) (stating that other creditors "would have some cause to complain" if a secured creditor used its status to seize property to which they had rights).

${ }^{173}$ See, e.g., Davoue v. Fanning, 4 Johns. Ch. 199, 202 (N.Y. Ch. 1819) (holding that a residuary legatee cannot maintain a bill without joining all the other residuary legatees); Ricketts, 3 Johns. Ch. at 555-56 (discussing defendants' objection that all the legatees concerned ought to have been made parties). 
that the decree can be fitly made between the parties before the court, without substantial injury to third persons. 174

A quite different approach to the problem of preclusion, however, was adumbrated in two New York cases. These led to a decree that would be binding on the absentees in some types of suits.

The first of these cases was a necessary parties case decided in 1829 , Hallett $v$. Hallett. ${ }^{175}$ The suit was a legatees' bill by two of several legatees to compel the devisee to pay their legacies from the estate. The defendant objected to the failure to join all the legatees, arguing that otherwise he might be subject to multiple claims. The court recognized that the necessary parties doctrine aimed at a decree "which will bind the rights of all, and prevent a useless multiplication of suits."176 At the same time, the court recognized that the decree ordering distribution from the assets of the estate would not bind absentees who were not joined in some way, for example, if they "came in and made themselves parties to the suit."177 But in the course of its discussion, the court made an interesting observation: "In all these cases the proceedings are in rem.",178

As far as we are able to determine, this is the first suggestion that a legatees' or creditors' bill type of representative suit is in rem. ${ }^{179}$ To conceptualize the proceeding as in rem of course opens the possibility of sweeping away all problems of joinder and all problems of res judicata. If a suit is in rem, the basis of the court's authority is shifted from party participation, or representation through another party, to the existence of a "res" before the court. If there is a res under the court's control, it can be said that all parties are before the court to the extent of any interest they might have in the res. By the same token, it can be said that all parties are bound by the

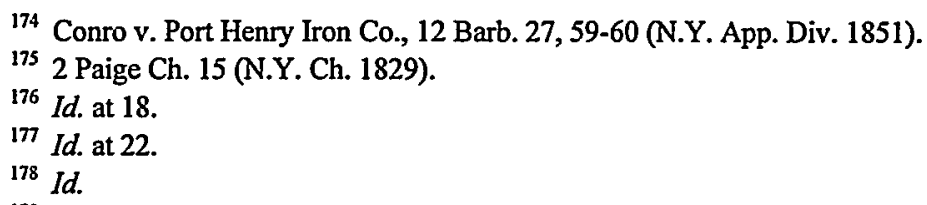

179 It is a remarkable fact, perhaps a coincidence, that in almost the same year that Hallett v. Hallett suggested a creditors' or legatees' bill could be regarded as an in rem proceeding, Justice Story had articulated the in rem concept of admiralty proceedings in The Nestor, $18 \mathrm{~F}$. Cas. 9 (C.C.D. Me. 1831) (No. 10,126), echoing a concept whose origin seems no earlier than United States v. Little Charles, 26 F. Cas. 979, 982 (C.C.D. Va. 1818) (No. 15,612), holding that a court of admiralty does not lose its jurisdiction to condemn the vessel by losing possession of it. See GRANT GILMORE \& CHARLES L. BLACK, LAW OF ADMIRALTY 591-94 (2d ed. 1975) (describing how "[t]hree cases of forfeiture of vessels for engaging in illegal activity seem to have introduced the personification idea into American law"); Edward F. Ryan, $A d-$ miralty Jurisdiction and the Maritime Lien: An Historical Perspective, 7 W. ONT. L. REV. 173, 199-200 (1968) (describing Justice Story's application of a "maritime lien" in The Nestor). 
decree to that extent as well. Indeed, that later became the theory of in rem and quasi in rem jurisdiction that prevailed down to Mullane v. Central Hanover Bank. ${ }^{180}$ This same concept is apparently the antecedent of what later is called the "common fund" type of class suit. ${ }^{181}$

The in rem concept articulated in Hallett $v$. Hallett was extended by degrees. In Wilder v. Keeler ${ }^{182}$ a dictum cast doubt on whether a creditor could come in "after the master has made his report,",183 that is, after notice and proof of claims but before final distribution. The master's report redefines the debtor's various assets and the creditors' various claims into an integrated schedule that is the equivalent of a fund. In Egberts $v$. Wood, the debtor's assets are described as a "fund." 184 Brooks v. Gibbons, ${ }^{185}$ a few years later, involved a creditors' bill that had gone to the first decree ordering claimants to submit their claims and in which the time for submitting claims had expired. The present plaintiff in Brooks alleged that he had no knowledge of the earlier suit, and sought to enforce his claim against those in possession of the debtor's assets. The court held that the plaintiff's proper remedy was to petition to come in under the decree in the original proceeding, not to bring a new suit. ${ }^{186}$ The court then said: "Whether a creditor can, in any case, institute an entirely new suit after a final decree in a former cause, under which he had a right to come in is at least doubtful." 187 In Innes $v$. Lansing, ${ }^{188}$ involving a statute governing insolvency of limited partnerships, the court described the "principle of the statute" as "treating the property of the limited partnership, after insolvency, as a trust fund for the benefit of all the creditors." 189

180339 U.S. 306, 318 (1950) (stating that "[e]xceptions in the name of necessity do not sweep away the rule that within the limits of practicability notice must be such as is reasonably calculated to reach interested parties").

${ }^{181}$ See FED. R. CIV. P. 23(b)(1)(B) (providing for a class action suit when individual adjudications of class members' claims would "as a practical matter" dispose of or interfere with other class members' interests). The "common fund" concept of a class suit was explicit in Rule 23(a)(2) before the comprehensive revision of Rule 23 in 1966. See Moore \& Cohn, Federal Class Actions, supra note 126, at 317 (explaining that a class action suit under Rule 23(a)(2) required both a common question of fact and "the presence of property which calls for distribution or management').

1823 Paige Ch. 164 (N.Y. Ch. 1832).

${ }^{183}$ Id. at 166.

1843 Paige Ch. 517,520 (N.Y. Ch. 1832).

1854 Paige Ch. 374 (N.Y. Ch. 1834).

${ }^{186}$ See id. at $377-78$.

${ }^{187} \mathrm{Id}$. at 377.

1887 Paige Ch. 583 (N.Y. Ch. 1839).

${ }^{189}$ Id. at 586. 
The conceptualization of a creditors' or legatees' bill as an in rem proceeding is quite novel. It does not appear to have been adopted previously in either creditors' bills or representative suits. Indeed, the in rem concept contradicted the then-existing precedents in creditors' and legatees' bill cases. Those precedents established that payment from the estate discharged the estate's administrator or executor, who by transferring the funds had performed his duty. ${ }^{190}$ The concept of the in rem proceeding extends even further: it signifies that the absentees could be precluded from pursuit of the distributees for contribution. Since the proceeding concerned the fund, distribution of the fund as such would be a conclusive adjudication of all of the absent claimants' rights of recovery. Hallett, therefore, marks the appearance of an entirely new conceptual basis for preclusion in at least some kinds of class suits.

The other interesting innovation in New York during this period was the representative suit brought by municipal taxpayers. Salient in this line of cases is DeBaun v. Mayor of New York. ${ }^{191}$ The case involved a suit by a municipal taxpayer in behalf of all taxpayers seeking to restrain a public official from entering into an allegedly unlawful construction contract, where the effect of the expenditure on the contract would be an increase in taxes. The decision in DeBaun sustained the suit partly on the basis of analogy to corporation and unincorporated business association cases. ${ }^{192}$ The defendant argued that allowing a single taxpayer to bring such a suit would permit any taxpayer to do the same, thus resulting in a multiplicity of suits. The court replied in dictum that the plaintiffs could not sue merely in their own behalf, but rather in behalf of all taxpayers in the city. The court stated that the effect of such a limitation would be that "[n]o other independent suit ... would be necessary or be permitted." 193

Here we encounter in embryonic form two concepts that later emerged as developed doctrine. One is that the shareholders of a corporation or members of an unincorporated association can represent the entity in bringing suit, benefiting the other shareholders or members via a judgment in favor of the entity. This, of course, is the essence of the derivative suit. ${ }^{194}$

${ }^{190}$ See supra notes 75-77 and accompanying text (listing creditor and legatee cases with this holding).

19116 Barb. 392 (N.Y. App. Div. 1853).

192 See id. at 395,399 (drawing a parallel between the rights to sue private corporations and public corporations).

193 Id. at 401.

${ }^{194}$ See FED. R. CIV. P. 23.1 (providing for an action by a shareholder or member of an unincorporated association to enforce a right possessed by the entity); see also AMERICAN LAW INSTITUTE, ALI'S PRINCIPLES OF CORPORATE GOVERNANCE (1994) (providing an overview of modern corporate law); ROBERT CHARLES CLARK, CORPORATE LAW 671 (1986) (de- 
The other idea is that the plaintiff taxpayers represent all other taxpayers, which is the essence of a class suit. ${ }^{195}$ The derivative suit and the class suit both involve representation, although not the same "constituency." It is not clear, therefore, whether the plaintiff taxpayers or stockholders represent the corporate entity, as opposed to the corporate directors and officers who ordinarily represent it, or purport to represent all the other taxpayers or stockholders. Moreover, it is unclear whether all taxpayers as members of the municipal community have the same interest as those who brought suit. Clearly members of such a group could have divergent interests. In DeBaun, the underlying divergence of interest was between the city's citizentaxpayers opposed to the project for which the contract had been entered and those in favor of the project. ${ }^{196}$ Some of the city's residents must have favored the project or the contract would not have been made. In previous association cases, this kind of intra-group conflict had been recognized as confounding and perhaps prohibitive of representative suits. ${ }^{197}$ The court in DeBaun nevertheless stated, although only in dictum, that all taxpayers would be bound by the suit brought only by a few. ${ }^{198}$

\section{The Fund Concept}

As noted above, Hallett $v$. Hallett suggests that at least some kinds of class suits can be conceived as in rem proceedings. ${ }^{199}$ Specifically, Hallett suggests that creditors' bills and legatees' bills can be conceived on the ground that they involve claims against a fund. It may be helpful at this point to take a closer look at the "fund" concept.

The practical task to be accomplished in both the creditor bill and the legatee bill involves compiling and then integrating two separate accounts. The first account is the schedule of claims by the creditors or legatees. The second account is the schedule of assets from which the claims are to be realized. Integration is effected by comparing the total of the two sums and proportionately reducing the claims in the event of insufficient assets. The schedule of claims in the creditors' bill is usually the more complicated of the two. This complexity is a product of conflicts that may arise both

fining derivative suits as "actions against officers that are by or in the right of the corporation").

${ }^{195}$ See DeBaun, 16 Barb. at 401 (explaining that the plaintiff does not bring suit merely in his own behalf but in behalf of all those similarly situated).

196 See id. at 395.

197 See supra notes 137-43 and accompanying text (discussing Story's explanation for court decisions in "association" cases).

198 See DeBaun, 16 Barb. at 401.

1992 Paige Ch. 15; see also supra notes 175-78 and accompanying text (containing a description of the suit). 
among the creditors as well as between the creditors and the debtor during the determination of the validity and amount of each of the claims. Among the creditors there is, of course, conflict between the secured and unsecured creditors, a conflict which the courts earlier held would prevent a single representation from acting for both. ${ }^{200}$ There is also conflict, however, among creditors, whether secured or unsecured, regarding any claim that is false, exaggerated, time-barred, defensible on the merits, or otherwise avoidable. If such a claim can be defeated, each other creditor gets a larger share of the debtor's assets.

Despite differences regarding the ultimate division of the assets, the creditors have a common interest in ferreting out the debtor's assets. Moreover, it ordinarily may be supposed, as the courts seem to have done, that most of the creditors are reasonably honest people whose claims are valid. Although there are conflicts of interest among creditors, there are also common interests, and these common interests predominate in the usual case. This configuration of interests permits and justifies a representative action aimed at collecting the assets and regulating their distribution. The representative has interests as against the debtor that create incentives to prosecute the suit effectively, even if he has interests hostile to his fellow creditors concerning division of the proceeds. Essentially the same analysis applies to the legatee bills.

We therefore must recognize that there is potential conflict within the group of creditors, specifically concerning the relative size and standing of their respective individual claims. These conflicts are not mitigated by conceptualizing the proceeding as involving a fund or as being in rem. To so conceive the proceeding simply restates the terms of the conflict. What before were parallel and conflicting in personam claims among the members of the group now become competing claims to the debtor's available assets. To say that the case involves a fund, and, on that basis, to say that a representative proceeding is appropriate, is only to say that there is enough common interest among the claimants to allow some of them to represent the remainder for the limited purpose of collecting the debtor's assets and thereby creating the fund. This can be said even if it is anticipated that, at the stage of dividing those assets, the group may dissolve into warring factions. That circumstance - that the group members have potentially conflicting interests as well as common ones-does not, however, vitiate the utility of common action for the common purpose. The concept of justice underlying the recognition that creditors have not only common but also

${ }^{200}$ See supra notes 84-85 and accompanying text (discussing the use of a supplemental bill). 
potentially conflicting interests is equivalent to that expressed in the modern bankruptcy doctrine of illegal preference. ${ }^{201}$

A more fundamental point emerges on further reflection-the creditors' bill proceeding has to recognize and be able to resolve the conflicts within the creditor group to allow the group's common interest to be given practical effect. If the conflicts within the group are not recognized, and a procedure established to resolve them, the debtor would have an unanswerable objection to parting with his property at the suit of any creditor. The objection would be that the distribution to any one creditor could prejudice other creditors, either if the debtor's assets are inadequate to pay all claims or if any one of the creditors' claims is both invalid and so large as to preempt other claims. In the creditors' bill proceedings, this point was given effect in the rule that the plaintiff creditor must sue for the benefit of all, including those fellow creditors with whom he might have a conflict of interest as to the size or validity of their respective claims. ${ }^{202}$

Thus, it is possible to say in the creditors' bill cases that there is a group with a "common" interest only by simultaneously assessing two legal relationships: first, the claims of the claimants as against the debtor taken as a whole, and, second, the claims of the claimants against each other. Assessing the claims of the claimants as a whole permits at least a tentative conclusion as to whether the claims exceed the assets and, therefore, whether the claimants have a common interest in getting unified control of these assets. It also is necessary, however, to assess the strength of the bond of common interest among the creditors.

The second relationship, the potential conflict among the creditors, appears most obviously where there are both secured and unsecured creditors involved. It is familiar in insolvency proceedings that these two classes of creditors may have conflicting interests; indeed, the debtor and the secured creditors may have common interests against the unsecured creditors in preserving the assets against unsecured claims. A similar conflict is possible among unsecured creditors, for example, where large creditors want a "work out" while small creditors want payment immediately, even if it requires a distress liquidation. The point is simply that in the creditors' bill cases, the

201 See DAVID G. EPSTEIN ET AL., BANKRUPTCY $§$ 6-3 (1993) ("Bankruptcy law aims to distribute the bankruptcy estate to the debtor's creditors in an order that corresponds to a prescribed hierarchy of classes of creditors."); Elizabeth A. Orelup, Note, Avoidance of Preferential Transfers Under the Bankruptcy Reform Act of 1978, 65 IOWA L. REV. 209, 209 (1979) ("The preference-a transfer of the debtor's property on the eve of bankruptcy to satisfy an old debt-is condemned by bankruptcy law because it thwarts the goal of equality of distribution of assets among all creditors.").

${ }^{202}$ See supra notes $80-81$ and accompanying text (providing an explanation for the rule that absentees are bound by the court's decree). 
existence of a plaintiff group with a common interest does not preexist the dispute of the debtor-the group's identity is a function of the dispute. Whether the group has identity depends on the relationship of common and conflicting interests among the various creditors and the debtor.

The underlying relationship in creditors' and legatees' cases, therefore, is threefold, with at least two contours of common and conflicting interest. Moreover, the shapes of these contours are interdependent and may be indeterminate until the litigation has progressed to the point of division of assets at the final decree. To say that there is a group with common interests who can be represented by one of its members is to speculate as to the configuration of interest. Often there may be a high degree of confidence that the speculation will be accurate, but not always so. Provision, therefore, has to be made that the speculation may eventually prove to be wrong. When the speculation is wrong, subgroups and separate representation sooner or later may have to be established. There also must be controls against selfserving opportunism on the part of the representative. ${ }^{203}$

These considerations do not necessarily foreclose the possibility of a representative form of proceeding in a "fund" situation. They do indicate, however, that the "fund" concept does not provide escape from the fact that the representative mechanism entails inherent risk of conflict within the represented group. In any event, no analytic gain is achieved by thinking of the dispute as involving a fund and the proceeding as being in rem. Indeed, that conceptualization can easily obscure the true complexity of the problem of conflicts.

\section{The Taxpayers' Suit}

The foregoing analysis concerning conflict and concert of interest in the creditors' bill representative suit is equally applicable to the taxpayers' suit. Analytically, or at least metaphorically, a taxpayers' suit also can be considered to involve a fund analogous to the creditors' bill. In the taxpayers' suit, the plaintiff is the representative either of all the individual taxpayers as a class or of the city in a derivative capacity. DeBaun v. Mayor of New

${ }^{203}$ In the historic doctrine we have reviewed, the control against opportunism on the part of the representative in creditors' bill proceedings was expressed in the rule that the plaintiff had to sue for the benefit of all and in the mechanism of the master's supervision of the accounting. See supra notes 88-94 and accompanying text (explaining the historical steps which resulted in the rule that absentee parties are bound by the court's decree). The modern counterpart is the rule holding the representative to fiduciary responsibilities and the mechanism of court supervision of the representative's conduct of the litigation. See FED. R. CIV. P. 23 (stating the rules applicable to class actions). 
York ${ }^{204}$ is a prototype of the taxpayers' suit, a model that is still valid today. ${ }^{205}$

In such a suit the relief sought is an injunction against expenditure. In substance, what is being protected is a pool of money collected or to be collected by the city from the taxpayers. To the extent that expenditure from the pool is reduced, the taxpayers enjoy what amounts to a rebate of taxation. Such a rebate is economically equivalent to the payment to creditors that results from a creditors' bill against a debtor. This underlying economic relationship also exists where the relief sought by the taxpayer is nonmonetary, for example, an injunction requiring the city to engage in certain conduct or to refrain from doing so. A course of conduct by the city entails costs or risks of liability which affect the city's balance sheet, which, in turn, affects the taxpayers' balance sheet of civic benefits and civic liabilities. This elementary economic learning is encapsulated in the pleading formula in the taxpayers' suit which alleges that taxpayers are in jeopardy of having their tax payments misspent. ${ }^{206}$

If the political character of the disputed course of action is more important than its economic consequences, then there are positive or negative effects on the community's political balance sheet. The analysis of political effects essentially parallels an economic analysis.

Whether the interests are calculated as economic or political, however, the taxpayers or citizens as a whole are never unanimous in their opinion about transactions that become the subject of a taxpayers' or citizen's suit. If they were unanimous, there would be no suit. The plaintiff alleges that he sues in behalf of all the taxpayers, but that is pure fiction. ${ }^{207}$ There is inherent conflict within the taxpayer group, just as there is inherent conflict within a creditor group. City expenditures or courses of action of even the most wasteful or illegal kind benefit someone; that is the reason they are undertaken. The serious question is not whether the taxpayers have an unconflicted common interest in enjoining the city from the apprehended course of action. The serious questions are whether one or more taxpayers should be allowed to contest the city's course of conduct in the courts, and if so, under what controls, and whether other taxpayers who support the

20416 Barb. 392 (N.Y. App. Div. 1853).

${ }^{205}$ See, e.g., Harman v. City \& County of San Francisco, 496 P.2d 1248 (1972) (stating that taxpayers had standing in a representative capacity to sue the city and county concerning the disposition of vacated city streets).

${ }^{206}$ See, e.g., Massachusetts v. Mellon, 262 U.S. 447, 486 (1923) ("[T] $]$ his plaintiff alleges ... that the effect of the appropriations complained of will be to increase the burden of future taxation and thereby take her property without due process of law.").

${ }^{207}$ See, e.g., Lynch v. Donnelly, 465 U.S. 668 (1984) (referring to "the city of Pawtucket" as if it were populated by a homogenous group). 
city's course of conduct will be adequately represented by the city or otherwise. $^{208}$

In the taxpayers' suit, as in the creditors' bill, it is therefore possible but not very helpful to think of the suit as involving a fund. It is likewise possible but positively misleading to think of the taxpayers as necessarily having a common interest, and therefore positively misleading to think of the taxpayers as a group. Rather, as in the creditors' bill, clarity of analysis requires that the taxpayers be considered as comprising two groups, and possibly more-those who are for the city's course of conduct and those who are against it to one extent or another. It is also positively misleading to think that the groups involved have an identity that is independent of the dispute. Rather, the terms of the dispute itself ultimately define the identity of the groups involved in the dispute.

None of this is changed by regarding the suit as derivative in behalf of the city. Conceiving of the suit as derivative may be a useful legal vehicle for accomplishing certain incidental purposes. The derivative suit concept, for example, may be a basis for insisting that the taxpayers all be treated equally in the final resolution, or for justifying payment of the plaintiff's attorneys fees out of public funds. ${ }^{209}$ The more substantial justification for allowing such a proceeding is that taxpayers are entitled to assurance that the city's public choices are in accordance with law emanating from higher public authority, such as the state or Federal Constitution. The taxpayers' suit, thus, is a mechanism for providing judicial review of decisions by municipal officials.

It is again perhaps appropriate to step back from procedural law and to consider the taxpayers' suit in a broader legal context. The taxpayers' suit, exemplified in DeBaun v. Mayor of New York, ${ }^{210}$ helped establish what has

${ }^{208}$ See Martin v. Wilks, 490 U.S. 755, $761-69$ (1989) (holding that city employees were not precluded from challenging city employment decisions arising pursuant to consent decrees entered by the city in a separate cause of action). In modern municipal law, it is now taken for granted that any taxpayer has standing to sue in a challenge to the legal validity of city action. See, e.g., Harman, 496 P.2d at 1254 ("IP]laintiff"s interest as a taxpayer in the outcome of the instant case establishes her standing to seek both equitable and legal relief against the city's allegedly wrongful disposition of its assets."). The problematic character of the alleged common interest being asserted by such a plaintiff, however, is fully revealed where the standing question is not taken for granted. See, e.g., Warth v. Seldin, 422 U.S. 490, 508-10 (1975) (denying standing to taxpayers in their action against the town because the alleged injury of an increased tax burden was conjectural and lacked a causal connection to the town's actions and because taxpayers could not show a personal right to bring the claim).

${ }^{209}$ See Serrano v. Priest, 569 P.2d 1303, 1309 (Cal. 1977) (affirming an award of attorneys fees to public interest law firms, because, in part, the benefits of the adjudications were widely enjoyed by the state's citizens).

21016 Barb. 392 (N.Y. Ch. 1853). 
become a uniquely American constitutional arrangement: the right of individual citizens to challenge actions of governmental agencies before the courts on grounds that the action was unconstitutional, ultra vires, or based on misinterpretation of the law or "arbitrary and capricious" decisionmaking. The taxpayers' suit and analogous proceedings may now be maintained not only against cities but also against state or federal governments. Correlatively, the exercise of reviewing authority by the courts has become virtually routine in disputes over governmental policy. The class suit, or something like it, is thus the procedural vehicle by which the American judiciary has come to function, in comparison with other modern democracies, such as a third house of Parliament.

The taxpayers' suit can be compared not only with the creditors' bill but also with the association cases. The association cases, it will be recalled, are those in which some members of an unincorporated association sue or are sued in behalf of the whole membership. ${ }^{211}$ These suits can be considered as being prosecuted or defended "by" all the members of the association through one of their members as a representative. They can also be conceived of as being "on behalf of" the association as an entity by such a representative, as in a corporate or taxpayers' derivative suit. ${ }^{212}$ Of course, to consider the association suit as a derivative suit in the right of the association is to presume that the association is a legal entity, but that would contradict legal doctrine as it stood in the nineteenth century. ${ }^{213}$ That, however, is a subsidiary point. Whatever legal doctrine might be, insofar as members of an association have continuing underlying interests, an association is an entity no less than a business corporation or a municipal corporation. Correlatively, insofar as members of an association have conflicting interests, an association is not a group but a set of groups which are in dispute with each other, just as in a dissident shareholder's derivative suit against incumbents in the corporate setting. Accordingly, a representative suit purportedly by or against an association entails the same problems of dealing with conflicting as well as common interests as are encountered in the creditors' bill and the taxpayers' suit.

That association situations could present problems of intragroup conflict, as well as conflict between the group and a third party, occasionally

211 See supra notes 104-18 and accompanying text (discussing an individual's authority to sue in behalf of a related group).

${ }^{212}$ See RESTATEMENT (SECOND) OF JUDGMENTS $\$ 61$ (1982) (stating that if an unincorporated association is not treated separately from its members, a "judgment in a section by or on behalf of the members of the association is binding on the members").

${ }^{213}$ See supra notes 139-42 and accompanying text (discussing circumstances under which designated representatives are not qualified to represent a certain group). 
was recognized in the early cases we have examined. The problem of intragroup conflict revealed itself dramatically in the most important of all nineteenth-century class suits, Smith v. Swormstedt. ${ }^{214}$

\section{Smith v. Swormstedt}

Smith v. Swormstedt stemmed from a controversy between the northern and southern wings of the Methodist Episcopal Church. ${ }^{215}$ The controversy had its roots in the slavery question, particularly the ownership of slaves by ministers of the church. The case echoed, if it did not directly address, the most complex and social issue with which American society has contended.

In 1844, the governing body of the national Methodist Episcopal Church authorized its Southern Annual Conference to depart, separating the church into northern and southern branches. At the time of the separation there existed a publishing business, the Book Concern, which published $\mathrm{Bi}$ bles. The profits of the Book Concern funded pensions for "travelling and worn out preachers."216 The northern branch asserted that in departing, the southern branch forfeited all rights to the Book Concern and its profits. To resist this assertion, a suit was filed by several members of the southern branch "by the authority, and under the direction of the General and Annual Conferences of the Church South, and for the benefit of the same, and for themselves, and ... all other ministers and persons having an interest in the property."217

The defendants named in the suit were Swormstedt, Finley, and Power, who were in charge of the Book Concern, and the travelling preacher section of the northern branch of the Church. The suit sought an accounting and an equitable apportionment of the Book Concern's property between the two branches. ${ }^{218}$

The Plaintiffs' theory was that the Methodist Episcopal Church had legally divided into northern and southern branches and that, as a consequence of this legal separation, members of each branch were entitled to a distributive share of all property held by the Church before the division, using the number of travelling preachers in the church north and south as the basis upon which to make the partition. ${ }^{219}$ The defendants' position was

21457 U.S. 288, 16 How. 307 (1853).

215 See id. at 288,16 How. at 307.

${ }^{216}$ Id. at 298,16 How. at 317.

217 Id. at 300,16 How. at 319.

${ }^{218}$ See id. at 288, 16 How. at 307 (detailing the history of the dispute between the divided Church over the Book Concern).

219 See id. at 299, 16 How. at 307 . The position of plaintiffs-appellants was summarized in their brief as follows: 
that the Methodist Episcopal Church had retained its identity when the southern branch seceded, "and submit[ted] that the separation and voluntary withdrawal from this church of a portion of the bishops, ministers, and members, and organization into a church south, was an unauthorized separation; and that they have thereby renounced and forfeited all claim ... to any portion of the property in question.",220

The procedural issue concerned the designation of parties. This issue apparently was raised for the first time before the Supreme Court, when the defendants-appellees objected that the plaintiffs were not proper parties. ${ }^{221}$ Although we do not have the complete briefs, nor a complete record of the argument, apparently the defendants took the position that the plaintiffs had no right to a distributive share either in their own right or in behalf of the absentee beneficiaries whom they represented. ${ }^{222}$

We claim, in the first place, that the division of the church was a valid act, and thereby the original church was divided into two churches equally legitimate, and that the members and beneficiaries in each have equal rights to their distributive share of all the property and funds.

Secondly. That if there was no valid division of the original church, but only a separation of the southern portion from the original church, yet, under the circumstances in which it was made, the beneficiaries of this charity have not lost that character by adhering to the church south, because the separation was authorized by the highest official and legislative authority of the church, and the beneficiaries living in the south had no choice or alternative but adherence to that church or the total loss of all church membership and privileges.

Id. at 288-89, 16 How. at 307-08.

${ }^{220} I d$. at 300-01, 16 How. at 319-20. The abstract of defendants'-appellees' brief describes their position as follows:

From 1844 to the present time, the same Methodist Episcopal Church has continued to exist identical in name, organization, discipline, and doctrine, and under a regular succession of the same officers: some conferences in the slave-holding States have withdrawn from it; it has lost and gained individual members; and the United States' possessions on the Pacific have been received into its connection; but these changes have not affected its organization or destroyed its identity.

Id. at 292-93, 16 How. at 311-12.

With respect to the property called the "Book Concern," appellees' counsel asserted:

I take it then as clear, by proof and by concession, that a Methodist Episcopal Church, having a regular and well known organization, existed prior to 1844, and that the property now in controversy was held by trustees, in trust for the church so organized, and for certain specified beneficiaries in it, and that it was only through its organization, in a mode pointed out by its organic law, that any individual was or could be entitled to any portion of the fund.

Id. at 292-93.

221 See id. at 301, 17 How. at 320 ("An objection was taken, on the argument, to the bill for want of proper parties to maintain the suit.").

${ }^{222}$ The defendants'-appellees' brief on this point is summarized as follows:

Do the individuals who join in this bill show any right to a distributive share of this fund? 
The Supreme Court concluded that both plaintiff and defendant classes were properly represented by the respective parties before the court. The Court said, in language that still echoes:

[W] here the parties interested are numerous, and the suit is for an object common to them all, some of the body may maintain a bill on behalf of themselves and of the others; and a bill may also be maintained against a portion of a numerous body of defendants, representing a common interest. ${ }^{22}$

This was a holding as to the plaintiffs and dictum as to the defendants.

In dealing with the problem, the Court drew largely upon Justice Story's Commentaries on Equity Pleadings. ${ }^{224}$ The Court, however, took no note of the qualifications and uncertainties that Story expressed in his treatise. ${ }^{225}$ The Court referred to Story's three categories of class suits, including the third in which the interests of the class members are "separate and distinct."226 Without addressing Story's hesitancies concerning the problem of the binding effect of the judgment, the Court asserted that when a class suit was permitted as an exception to the Necessary Party Rule, the decree was binding on the absentees so long as those present as parties fairly represented the absentees' interests: "The legal and equitable rights and liabilities of all being before the court by representation, and especially where the

They show that they "are preachers-Kelley and Allen are supernumerary, and Tevis superannuated preachers-of the Methodist Episcopal Church South, and that as such they have a personal interest in the real estate, personal property, debts, and funds now holden by the Methodist Episcopal Church through said defendants, as agents and trustees appointed by the General Conference of the Methodist Episcopal Church." So much for themselves.

As to those whom they choose to represent, they say, "[t]hat there are about fifteen hundred preachers belonging to the travelling connection of the Methodist Episcopal Church South, each of whom has a direct personal interest in the same right as your complainants to the said property,"

They say they are members of the church south, preachers belonging to the travelling connection of that church, and on that ground, and that alone, they set up this claim. They do not aver that they, or any one of them, or any one for whom they appear, ever belonged to the Methodist Episcopal Church, and acquired rights in its connection; but they simply claim that, by virtue of their connection with the Methodist Episcopal Church South, they are entitled to a distributive share of the property of the Methodist Episcopal Church. The case is certainly no better by making these persons complainants. If the church south be not entitled, as an organized body, on some ground shown in the bill, these persons are not entitled because they are members of its organization.

Id. at 295-96, 16 How. at 314-15.

${ }^{223}$ Id. at 301-02, 16 How. at 320-21.

${ }^{224}$ See STORY supra note 74, at 74 and accompanying text ("Persons materially interested ... in the subject-matter of a suit are to be made parties to it.").

${ }^{225}$ See id. at 74-204 and accompanying text (discussing the proper parties to a bill).

${ }^{226}$ Swormstedt, 57 U.S. at 302, 16 How. at 322. 
subject-matter of the suit is common to all, there can be very little danger but that the interest of all will be properly protected and maintained."227

It is not clear what the Court meant by these words about the conditions under which a class suit would be binding on members of a class. Whatever it said was dictum, because the question at issue was one of proper parties and not the effect of the judgment. In any event, the Court was apparently of the view that the conditions required for the class suit device included "numerousness" of interested parties and the existence of a common question in which the class members had consistent rather than conflicting interests. ${ }^{228}$ The implication of the Court's discussion is that the decree would be binding whether or not the class might have other characteristics, such as the fact that its members belonged to an association, or that a "fund" was involved. Hence, we have a clear statement that a class suit decree is, at least under certain circumstances, binding on absentee members of the class. If we are correct in our historical research, Smith $v$. Swormstedt is indeed the first unequivocal statement to that effect about a class suit.

The statement in Swormstedt that a class suit decree is binding on absentees was made in a case where the relevant group could be defined according to any one of the categories by which class suit doctrine had been formulated. The classes involved in Swormstedt also can be analyzed via the concepts now found in Federal Rules 23 and 23.2..$^{229}$ Swormstedt can be considered an association case, with representatives of an association (the southern branch) as plaintiffs and representatives of another association (the northern branch) as defendants, acting in behalf of all members of the respective associations. Swormstedt can be equally well regarded as a derivative suit by constituents of the organization contending that the management had been mismanaging the affairs of the organization. In addition, Swormstedt can be considered a "fund" case, in which the Book Concern and its stream of profits was a res over which the Court had control and of which it could make a division among the group of claimants. It also can be considered a "common question" situation that, in the words of Federal Rule 23(b)(2), occurs when "the party opposing the class has acted or refused to act on grounds generally applicable to the class, thereby making appropriate final injunctive relief or corresponding declaratory relief with respect to the

227 Id. at 303,16 How. at 323.

${ }^{228}$ See id. at 302,16 How. at 322 ("The rule is well-established that where the parties interested are numerous and the suit is for an object common to them all, some of the body may maintain a bill on behalf of themselves and of the others.").

${ }^{229}$ See FED. R. CIV. P. 23 ("Class Actions"); FED. R. CIV. P. 23.2. ("Actions Relating To Unincorporated Associations"). 
class as a whole.,230 It, of course, also can be considered a situation in which the key is simply the "numerousness" of the parties and the similarity of their legal situations.

In any event, the statement in Smith v. Swormstedt that "the decree binds all of them the same as if all were before the court"231 completely overlooked an important development in the rules governing absentee members of a class-the revision of the Federal Rules of Practice for the Court of Equity, particularly Rules 47 and 48, which the Supreme Court had promulgated in $1842 .^{232}$

\section{E. Rule 48 of the Equity Rules of 1842}

Rule 47 of the Equity Rules of 1842 dealt generally with the problem of necessary parties. Rule 48 dealt with situations "[w]here the parties on either side are very numerous." 233 The two rules addressed the effect on unjoined parties in slightly different language. The formulation in Rule 48, however, stated that "the decree shall be without prejudice to the rights and claims of all the absent parties."234

That Smith v. Swormstedt makes no mention of Equity Rule 48 is an astonishing fact. But a fact it is.

As of 1854, therefore, the leading decision by the Supreme Court said that absentees in a representative suit were bound, apparently without regard

${ }^{230}$ FED. R. CIV. P. 23(b)(2); cf. FED. R. CIV. P. 23(b)(1) (providing for class status when "the prosecution of separate actions by or against individual members of the class would create a risk of ... inconsistent or varying adjudications ... or [conflicting adjudications]").

231 Swormstedt, 57 U.S. at 302, 16 How. at 322.

232 Rule 47 provided:

In all cases where it shall appear to the Court that persons, who might otherwise be deemed necessary or proper to parties to suit, can not be made parties by reason of their being out of the jurisdiction of the court, or incapable otherwise of being made parties, or because their joinder would oust the jurisdiction of the court as to the parties before the court, the Court may, in their discretion, proceed in the cause without making such persons parties; and in such cases the decree shall be without prejudice to the right of the absent parties.

Rule 48 provided:

Where the parties on either side are very numerous, and can not, without manifest inconvenience and oppressive delays in the suit, be all brought before it, the Court in its discretion may dispense with making all of them parties, and may proceed in the suit, having sufficient parties before it to represent all the adverse interest of the plaintiffs and the defendants in the suit properly before it. But, in such cases, the decree shall be without prejudice to the rights and claims of all the absent parties.

42 U.S. (I How.) lv, lvi (1842), reprinted in JAMES LOVE HOPKINS, THE NEW FEDERAL EQUTTY RULES 103-C5 (W.H. Anderson Co. 1913).
233 Id. at 104.
234 Id. at 105. 
to the type of class, while the Equity Rules it had promulgated only a decade earlier said that absentees were not bound, again apparently without regard to the type of class. From that point at least until 1912, when the Equity Rules were further revised, ${ }^{235}$ Rule 48 and Swormstedt coexisted in peaceful contradiction. The courts progressed case by case, almost never referring to both Rule 48 and Swormstedt in the same decision and never confronting the inconsistency.

In the process, the courts invoked a term on which Story relied to make sense of the earlier decisional law. This was the phrase "a common interest or a common right."236 This phrase had been appropriated in Smith $v$. Swormstedt, in the Court's statement that a representative action may be maintained "where the parties are very numerous, and though they have or may have separate and distinct interests.... [T]hough the rights of the several persons may be separate and distinct, yet there must be a common interest or a common right, which the bill seeks to establish or enforce."237

"Common right" thus came to be employed as the formula, or as an additional formula, to identify a representative suit that would have binding effects.

\section{SMITH V. SWORMSTEDTTO BEN-HUR V. CAUBLE}

\section{A. Federal Cases 1854-1912}

After Smith v. Swormstedt in 1854, there were few reported class suit cases in the federal courts until the 1880 s. The two we have been able to identify involved the question of initial joinder rather than the question of res judicata. Both interpreted the "common interest" requirement narrowly.

In Ayres v. Carver, ${ }^{238}$ decided very shortly after Swormstedt, the plaintiff brought an action against approximately 200 defendants. The plaintiff alleged that he had made an offer to buy land from the government at a statutorily established price, but that the offer had been refused by the defendant register of the Government land office. The plaintiff further alleged that the other defendants had later purchased the same land with knowledge of the plaintiff's prior right to purchase. The plaintiff sought to set aside the

${ }^{235}$ Rule 38 of the revised Equity Rules of 1912 provided: "When the question is one of common or general interest to many persons constituting a class so numerous as to make it impracticable to bring them all before the court, one or more may sue or defend for the whole." 226 U.S. 649, 659 (1912).

${ }^{236}$ STORY, supra note 74 , at 120.

${ }^{237}$ Swormstedt, 57 U.S. at 302, 16 How. at 322.

23858 U.S. 591, 17 How. 620 (1854). 
purchases of the parcels of the land that had been sold to the defendants. ${ }^{239}$ The district court appointed several of the defendants to represent the class. Citing Swormstedt, the Supreme Court in dictum stated that:

[I]t is difficult to see any interest or estate in common among these several defendants, that would authorize the rights of the absent parties to be represented in the litigation by those upon whom process has been served.... Their title to the land ... is separate and independent, without any thing in common

The Court seems not to have considered that there was a common issue as to whether plaintiff's offer to buy was wrongfully refused, even though there was also the separate issue of whether each individual defendant had been aware of the plaintiff's claim at the time he bought his parcel.

In a district court case, Cutting v. Gilbert, ${ }^{241}$ the common interest requirement was given even more restrictive effect. In that case, several New York brokerage firms sued in behalf of themselves and all others similarly situated who might join the suit and contribute to its expenses. The suit sought to enjoin the collection of a tax under the Internal Revenue Act of 1864. The court dismissed for improper joinder of parties. ${ }^{242}$ The plaintiffs could not represent the absent parties, the court said, because the parties must have a common interest, not merely in "the question" at issue, but in "the subject matter of the suit.",243

This reasoning was invoked by the Supreme Court toward the end of the nineteenth century in Scott $v$. Donald, ${ }^{244}$ a case involving a South Carolina law regulating importation of alcoholic beverages. In Scott, the plaintiff, a liquor importer, sued for himself and for all other persons in the state, attacking the regulation as unconstitutional and asking for an injunction to restrain state officials from enforcing it. The Supreme Court held that the law was unconstitutional but modified the injunction to enjoin only the named officials and to protect only the plaintiff himself. ${ }^{245}$

${ }^{239}$ See id. at 592 ("The complaint then prays ... that the several entries and purchases made by the defendants be set aside .....").

240 Id. at 594.

${ }^{241} 6$ F. Cas. 1079 (C.C.S.D.N.Y. 1865) (No. 3519), affd sub nom. United States v. Cutting, 70 U.S. 441 (1866).

${ }^{242}$ See id. at 1080 ("[T] his bill cannot be sustained, on account of the joinder of improper parties as plaintiffs.").

${ }^{243} I d$.

244165 U.S. 107 (1897).

${ }^{245}$ See id. at 117 (pronouncing that "certain provisions of the act in question [are] unconstitutional," but directing that "[t] he decree of the court below . . . be amended by being restricted to the parties named as plaintiff and defendants in the bill"). 
Other cases also dealt with the ex-ante problem of joinder rather than the ex-post problem of res judicata. Thus, there were cases in which a third party sought intervention to assert claims in creditors' bills and similar proceedings. ${ }^{246}$ It was indicated that when a party intervened in such a suit, he became an actual party; if he did not intervene, then the suit could be deemed not to have been brought in his behalf. This ambiguity permitted the courts to regard such suits as representative for purposes of the rules regarding necessary parties, but not for precluding the absentees from subsequently initiating a suit in their own right. ${ }^{247}$

Another doctrinal compromise involved resuscitation of the old concept of "quasi parties." This approach was taken in Terry v. Bank of Cape Fear. ${ }^{248}$ Following the insolvency of the Bank of Cape Fear, the plaintiff sued in behalf of himself and all other creditors to impose individual liability on the bank's shareholders in accordance with state law that imposed such liability on shareholders in banks. Twenty-five shareholders were named to represent the defendant shareholder class. Judgment was given for the plaintiffs, and a commissioner was appointed to ascertain the amounts due to each creditor and owed by each shareholder. ${ }^{249}$ The court characterized both the absent shareholders and the absent creditors as quasiparties, ${ }^{250}$ meaning that a quasi-party plaintiff could receive the benefits of the decree but that a quasi-party defendant could not be prejudiced by it. ${ }^{251}$

${ }^{246}$ See, e.g., Bacon v. Robertson, 59 U.S. 480, 489, 18 How. 40, 41 (1855) (allowing a suit by a stockholder representing the interests of all stockholders in bank assets); Compton v. Jesup, 68 F. 263, 285-86 (6th Cir. 1895) (finding that a lien holder on foreclosed property was not estopped from asserting the lien by judgment in a suit brought by other bondholders generally when the lien holder did not join that suit).

${ }^{247}$ See Wabash R.R. v. Adelbert College of the W. Reserve Univ., 208 U.S. 38, 58-59 (1908) (finding that a judgment in a suit brought in behalf of stockholders was not binding on stockholders who could have, but did not, join the suit); United States v. Old Settlers, 148 U.S. 427, 479-81 (1893) (holding that the general liability of the United States was established in a suit brought by three commissioners in behalf of the Western Cherokee Nation, but individual claimants must come in and prove their right to share in the fund); Compton v. Jesup, $68 \mathrm{~F}$. at $285-86$, discussed supra note 246.

${ }^{248} 20$ F. 777 (C.C.W.D.N.C. 1884) (explaining that a "decree was made, declaring and adjudging the right of the plaintiffs ... to recover their debts," and that a commissioner was directed to "assess each defendant with the amount of his proportionate liability").

${ }^{249}$ See id. at 778.

${ }^{250}$ See id. at 780-81 (declaring that the stockholders were quasi parties who could not "be compelled to pay their proportionate amount ... as they were not actual parties," and asserting that the absent plaintiffs were "deemed quasi parties, and have an inchoate interest in the suit").

${ }^{251}$ Other cases held that a creditor who did not come in and prove his claim before the master could not thereafter bring a separate suit in his own right. See, e.g., Leadville Coal Co. v. McCreery, 141 U.S. 475,478 (1891) (holding that a person who was assumed to be a creditor, but who did not come forward to present his claim, was not entitled to a recovery); 
The cases in this period dealing directly with res judicata became entangled in an underlying social conflict that has long been difficult, perhaps intractable: Can individual members of a labor union be punished for contempt of court for continuing a strike in the face of an injunction prohibiting the strike that has been obtained against the union and its officers? The problem has many layers: the immediate labor-management conflict; the class conflict inherent in industrial labor relationships, not only between workers and proprietors, but between workers and the educated class that includes lawyers and judges; the conflicting loyalties of union members as citizens and as union members; the conflicting purposes of union leadership; and the uncertainty of cohesion within the membership.

The immediate question in these cases was whether union members neither named as parties nor served with process were obliged to refrain from picketing on the basis of an injunction against the union and its officers. In re Lennon, ${ }^{252}$ decided by the Supreme Court in 1897 , provides that such an injunction imposed an obligation to refrain from picketing on an employee who had not been an actual party to the suit: "To render a person amenable to an injunction it is neither necessary that he should have been a party to the suit in which the injunction was issued, nor to have been actually served with a copy of it, so long as he appears to have had actual notice., 253

In 1898, in the case of American Steel \& Wire Co. v. Wire Drawers' \& Die Makers' Unions Nos. $1 \& 3,{ }^{254}$ this obligation was described in terms that suggested it was based on res judicata:

[I]t is one of the features of an interlocutory injunction that it reaches all who are parties, whether they have been served with process of subpoena or not, whether they have appeared or not, whether they have answered or not; and it binds all who have notice of it, whether they are parties or not. ${ }^{255}$

This proposition clearly suggests a res judicata effect on absentees. Hence, it was consistent with the proposition in Swormstedt that a class suit decree is binding on members of the class who are not actual parties to the suit. The proposition was, of course, inconsistent with Equity Rule 48 adopted in 1842 , which was then still in force. ${ }^{256}$ However, there is an in-

Richmond v. Irons, 121 U.S. 27, 66 (1887) (same); cf. supra notes 88-94 and accompanying text (discussing how a creditor could collect his debt by joining a representative creditors' suit once an initial decree in that suit had been issued, and noting that creditors who joined the representative suit later were accommodated until the final decree was issued).

252166 U.S. 548 (1897).

${ }^{253}$ Id. at 554.

25490 F. 598 (C.C.N.D. Ohio 1898).

255 Id. at 604.

256 See supra note 232. 
dependent basis for an obligation to respect an injunction by one who is not bound as a party, or as represented by a party, but who has notice of the court order. The obligation results not from res judicata but from refraining from obstruction of justice. The Eighth Circuit recognized this distinction in a later case. ${ }^{257}$

The fact nevertheless remains that the court in American Steel \& Wire $C o$. analyzed the problem as one involving the preclusive effects on absentee members of a class. ${ }^{258}$ The court evidently had great difficulty grappling with this issue, saying on the one hand that the decree binds absentees if "the persons brought on the record fairly represent the interest or right involved,"259 but on the other hand that "all absent parties [would be] protected by ... the reservation of equity rule $48 .{ }^{.260}$ This is one of the few cases in the period following Swormstedt that refers to Equity Rule 48.

Another case relying on Equity Rule 48 was Coann v. Atlanta Cotton Factory Co. ${ }^{261}$ which held that absentees were not bound by the decree in a representative creditors suit. In Coann, the creditors' representative foreclosed on land that was the subject of certain trust deeds, obtaining a decree under which the land was sold. Afterwards, another creditor sought to have the decree set aside. The court held that absent creditors were not bound:

The equity rules that allow suits to be brought by some complainants for the benefit of all, expressly reserve the rights of absent parties. See Equity Rules 47 and 48 . The absent bondholders are not quasi parties.... It follows that, as the absent bondholders are not bound by the decree, they may inaugurate new proceedings.... ${ }^{262}$

But there were also holdings that bound absentees, an important instance being Wallace $v$. Adams. ${ }^{263}$ This case arose under special legislation that created a court to determine Native American citizenship claims-another deep underlying social conflict to which the class suit device has been put to use. The Supreme Court held that the defendant was bound by a de-

${ }^{257}$ See In re Reese, 107 F. 942, 945-46 (8th Cir. 1901) (asserting that a party, although not a named party to an injunction, may be punished for knowingly aiding in the violation of the injunction); see also RESTATEMENT (SECOND) OF JUDGMENTS $\S 63$ (1982) (discussing the duty not to obstruct compliance with a judgment).

${ }_{258}$ See $90 \mathrm{~F}$. at 605 (discussing whether an injunction can "bind persons not formally parties to the bill").

259 Id. at 607.

$260 \mathrm{Id}$. at 606.

26114 F. 4 (C.C.N.D. Ga. 1882).

${ }^{262}$ Id. at 8.

${ }^{263} 204$ U.S. 415 (1907). 
cree in an earlier representative action to which he had not been a party. ${ }^{264}$ The Supreme Court pointed out that the defendant had not availed himself of a legislative provision allowing claimants to make their claims individually, but described this provision as an "extra precaution,"265 thus implying that the defendant would have been bound even without opportunity to be heard individually:

[I]t is undoubtedly within the power of a court of equity to name as defendants a few individuals who are in fact representatives of a large class having a common interest or a common right... and make the decree effective not merely upon those individuals, but also upon the class represented by them. ${ }^{266}$

Earlier, in Hawkins v. Glenn, ${ }^{267}$ the Court held that a decree against a corporation, requiring an assessment of its shareholders, bound shareholders who had not participated in the suit, even though the corporation had been represented only by a court-appointed trustee rather than a member of the class. ${ }^{268}$ The Court in Swan Land \& Cattle Co. v. Frank ${ }^{269}$ ruled, however, that creditors could not sue shareholders as representatives of the corporation to collect on corporate obligations because the judgment could not bind either the corporation or the other shareholders. ${ }^{270}$

In all of the cases thus far cited, the question of binding the absentees was framed in terms of formal characteristics of the representative relation-

${ }^{264}$ See id. at $425-26$ (asserting that "it is undoubtedly within the power of a court of equity to name as defendants a few individuals who are in fact representatives of a large class having a common interest ... and make the decree effective ... upon the class represented by them," and therefore affirming the decision of the lower court).

${ }^{265} I d$. at 425.

${ }^{266}$ Id. Perhaps it need not be added that the Court gave no attention to Equity Rule 48 in reaching its conclusion. See also McIntosh v. City of Pittsburgh, 112 F. 705, 707-09 (C.C.W.D. Pa. 1901) (finding a prior state court proceeding preclusive in a subsequent federal suit); Gamble v. City of San Diego, 79 F. 487, 500 (C.C.S.D. Cal. 1897) (noting that a pending federal representative suit precludes initiation of a second such suit).

267131 U.S. 319 (1889).

${ }^{268}$ See id. at 329 (declaring that "the stockholder is bound by a decree of a court of equity against the corporation in enforcement of a corporate duty, although not a party as an individual, but only through representation by the company"); see also Beals v. Illinois, Mo. \& Tex. R.R., 133 U.S. 290, 295 (1890) (considering bondholders fully represented and bound by a decision in a suit in which the trustee was a party); Kerrison v. Stewart, 93 U.S. 155, 160 (1876) (finding that beneficiaries of a trust are bound by judgment in a suit in which the trustee was a party and acting in their behalf); San Francisco Gas \& Elec. Co. v. City of S.F., 164 F. 884, 886 (C.C.N.D. Cal. 1908) (finding an injunction properly applicable to unnamed parties when named parties are in a representative or trust relation to them); Campbell v. Railroad Co., 4 F. Cas. 1178, 1181 (C.C.E.D. Tex. 1871) (No. 2366) (same).

269148 U.S. 603 (1893).

${ }^{270}$ See id. at 610 (asserting that corporations "are indispensable parties to a bill which affects corporate rights or liabilities," and that unless a corporation were made a party to the proceeding, neither it nor its other stockholders would be bound by the decree). 
ship_-common interest" and similar concepts. The opinions sometimes referred to "identity of interest" and the propriety of a representative standing for absentees. What we now call "adequacy of representation" was not part of the analysis.

The first recognition of the concept of adequacy of representation in terms even approximating the modern conception seems to be McArthur $v$. Scott, ${ }^{271}$ decided in 1885 . That case involved an absentee who was formally but inadequately represented. The facts were as follows. Duncan McArthur died in 1839 , leaving a will that gave the income from certain properties to his children for their lives and then directed that, when the children had all died and the youngest grandchild had attained the age of twenty-one, the properties were to be distributed to his grandchildren. One of McArthur's sons contested the will, alleging that the will was impossible to carry out, that it was in violation of the Rule Against Perpetuities, and that McArthur had lacked testamentary capacity. ${ }^{272}$ McArthur's other children and grandchildren were named as defendants in that suit. In that earlier suit, the court appointed the parents of several grandchildren to act as guardians ad litem for the latter. None of the defendants contested the allegations, and the will was found invalid. ${ }^{273}$ The estate was then distributed by intestacy to McArthur's children, and portions of the property were subsequently sold. In 1875, after McArthur's youngest grandchild reached the age of twenty-one, he and his sisters sued the other grandchildren and the transferees of the property, claiming that the will was valid and therefore that title to the property should devolve to them. After an unfavorable decision in the district court, these grandchildren appealed to the Supreme Court. $^{274}$

An unborn grandchild plainly could not have been made an actual party to the original will contest proceeding. The question, therefore, was whether his interests had been represented by other parties in that proceeding. In answering this question, the Court focused on two factors. First, it noted that the interests of the parties to the earlier proceeding had been inconsistent with those of the present plaintiffs because the earlier defendants as heirs stood to take a larger interest through intestate succession than they

271113 U.S. 340 (1885).

272 See id. at 348 (recounting the allegations in the bill filed by McArthur's eldest son).

${ }^{273}$ See id. at 350 (noting that the defendants "stated that they would neither admit nor deny the allegations of the bill," and that a jury subsequently found that "the instrument is not the valid last will and testament of the said Duncan McArthur deceased").

${ }^{274}$ See id. (dismissing the bill filed by the grandchildren), rev'g McArthur v. Allen, $3 \mathrm{~F}$. 313, 324 (C.C.S.D. Ohio 1880). 
would take under the will. ${ }^{275}$ Hence, in the original proceeding, it had not been in their interest to defend the validity of the will. Second, the Court found that the representation had, in fact, been deficient since the contestants' allegations had not even been controverted, let alone adjudicated. ${ }^{276}$ On this basis, the present plaintiffs had not been fairly represented and, accordingly, were not bound by the decree. But the ambivalence in the Court's language is remarkable:

In suits affecting the rights of residuary legatees ... the general rule is that all the members of the class must be made parties .... Where they are numerous, and only some of them ... are made parties, the court, upon being satisfied that it has a sufficient number before it to secure a fair trial of the question at issue, may hear the cause.... But it would seem that the decree must be without prejudice to the rights of those who are not made parties.... 277

As far as we have been able to ascertain, this is the first case in which adequacy of representation as such was advanced as the decisive criterion in determining the binding effect of a class suit.

\section{B. The State Cases: $1860-1940$}

While the federal courts struggled to articulate a theory of preclusion in representative suits, the states, suffering complications from the contradiction between Smith $v$. Swormstedt and Equity Rule 48, dealt with the same problem with perhaps less doctrinal confusion. The apparent clarity in doctrine may have resulted in part from the fact that the lines of state cases tended to stay in case-types-taxpayer cases, creditors' bills cases, and so on-among which there was less tendency to generalize. This compartmentalization avoided the internal contradictions in the generalizations being uttered in the federal decisions, but only by ignoring the contradictions between the categorical compartments in state law.

${ }^{275}$ See Scott, 113 U.S. at 359 ("Representation by an adverse interest is an absurdity which the law does not contemplate.").

${ }^{276}$ See id. at 394-95 (stating that the interests of the unborn grandchildren and greatgrandchildren were not represented in the original suit since the heirs at law, whose interest was to set aside the will, in fact controlled both sides of the controversy). The failure to contest in the first litigation concerning the property suggests that the former proceeding was collusive. See Hansberry v. Lee, 311 U.S. 32, 44-45 (1940), discussed infra at note 428 and accompanying text (noting that the Court was bound by the Illinois Supreme Court's finding that the suit was not collusive); see also Scott, 113 U.S. at 394 (finding that the verdict and decree could not be applied to the then unborn parties since they were "entered without any contest").

277 Scott, 113 U.S. at 395. 
There is another curious fact-a high fraction of the state cases were from Illinois, including Hansberry v. Lee ${ }^{278}$ which came before the Supreme Court in 1940. The cases in this period can be grouped into four categories: "virtual representation" of remaindermen in intergenerational property transfers, ${ }^{279}$ taxpayer suits, creditors' bills, and bills of peace.

Cases involving remaindermen typically arose when a will or trust instrument created several classes of beneficiaries, one of which consisted of unborn contingent remaindermen. If the testamentary disposition later was contested, the necessary parties doctrine created a serious problem. Under the Necessary Parties Rule, the action could not proceed without all "interested" parties, including contingent remaindermen. ${ }^{280}$ At the same time, where such remaindermen were as yet unborn, it was literally impossible to join them. Some device or explanation for permitting the action to proceed had to be created to permit authoritative adjudications of rights in the decedent's property.

Permitting the action to be tried in the absence of necessary parties was, of course, only the first problem-that of the ex-ante joinder procedure. The second problem was whether, under the rules of res judicata, members of the unborn class would be bound by the judgment. Practical utility required some conceptual device for binding the absentees. Otherwise, a trustee or living beneficiary would have great difficulty selling property or investing in development of the property from the trust corpus because title would not be marketable if the absent remaindermen were not bound by a judgment determining the remaindermen's interests.

The doctrine that evolved, specifically associated from the remaindermen cases, was that of "virtual representation." The rule was that living remaindermen "virtually represented" the whole category of remaindermen, at least where their interests did not conflict. The leading case was Hale $v$.

278311 U.S. 32 (1940).

279 An illustration of a "virtual representation" type of case is McArthur v. Scott, 113 U.S. 340, discussed supra at notes 271-77 and accompanying text. The cases involving virtual representation generally are representative suits but not necessarily class suits. They are representative in structure and in theory, because unborn remaindermen could be considered as parties only through some concept of representation. They are not necessarily class suits because the unborn remaindermen were not always thought of as "numerous." It is imaginable that a set of children could procreate grandchildren at a rate that would qualify for numerousness. For purposes of a theory of representation, however, it makes little difference how many are in the set of absentees. The crucial fact is that the absentees are absent.

${ }^{280}$ See Scott, 113 U.S. at 391-92 ("The general rule in equity, in accordance with the fundamental principles of justice, is that all persons interested in the object of a suit, and whose rights will be directly affected by the decree, must be made parties to the suit."). 
Hale. ${ }^{281}$ Drawing extensively upon English and American cases, as well as upon Story and other treatise writers, the court in Hale held that representation both circumvented the Necessary Parties Rule and resulted in preclusion of absent class members. ${ }^{282}$ The rule was stated as follows: "Thus, where it appears that a particular party, though not before the court in person, is so far represented by others that his interests receive actual and efficient protection, the decree may be held to be binding upon him."283

Other cases of the same era in Illinois and elsewhere had similar results. ${ }^{284}$ Subsequently, there was increasing emphasis on the adequacy of representation, as distinct from formal identity of interest. ${ }^{285}$ Nevertheless, the inference is inescapable that many of the cases were friendly proceed-

28133 N.E. 858 (IIl. 1893); see also McCampbell v. Mason, 38 N.E. 672, 674 (Ill. 1894) (holding that a foreclosure decree is binding on those whose interest in a contingent remainder is of the same class as the parties actually present before the court).

282 See Hale, 33 N.E. at 867-68 ("If persons in being are before the court who have the same interest and are equally certain to bring forward the entire merits of the question ... convenience and justice require that there should be a complete decree.").

283 Id. at 867.

${ }^{284}$ See Elmore v. Galligher, 87 So. 349, 351 (Ala. 1921) (holding that the property rights of unborn contingent remaindermen may be extinguished by judicial decree where the remaindermen have been virtually represented under strict standards); Wolf v. Uhlemann, 156 N.E. 334, 340 (Ill. 1927) (holding that remaindermen not in esse were sufficiently represented by living members of the same class in a compromise family settlement); Easton v. Hall, 154 N.E. 216, 225 (Ill. 1926) (holding that the equity nule which states that parties not before a court are not bound by its decrees may be excepted where parties are represented and their interests are adequately protected); Weberpals v. Jenny, 133 N.E. 62, 66 (III. 1921) (holding that the unborn remaindermen of a will were not bound by court decree because their interests had not been adequately protected as to satisfy the equity doctrine of representation); Longworth v. Duff, 130 N.E. 690, 691-92 (Ill. 1921) (holding that a decree regarding the contingent interests of remaindermen not before the court was binding if the full merits of these interests had been brought forward by persons of the same interest); Kent v. Church of St. Michael, 32 N.E. 704, 705 (N.Y. 1892) (holding that a court judgment in accordance with a deed was binding on grandchildren not in esse and that the deed therefore conveyed perfect title); New York Life v. Conkling, 144 N.Y.S. 638, 641 (App. Div. 1913) (holding the two grandchildren not in esse at the time of the agreement to be bound to the judgment of compromise since their interests in the trust estate were "precisely similar" to those of the grandchildren who were parties to the suit); Faber v. Faber, 56 S.E. 677, 679 (S.C. 1907) (holding that where an issue is of general interest to many persons and it is impractical or impossible to bring all of them before a court, one party may be made a representative defendant in the case).

${ }^{285}$ See Mortimore v. Bashore, 148 N.E. 317,319 (Ill. 1925) (holding that a decree granting fee title against the interests of the unborn was invalid because the interests of the unborn parties were not adequately represented by the parties before the court); Thompson v. Humphrey, 101 S.E. 738, 746 (N.C. 1919) (holding that the grandchildren of a testator were not represented by the testator's children as they were two distinct classes with hostile interests); Chambers v. Preston, 193 S.W. 109, 112 (Tenn. 1917) (holding that, in partition suits in which the actual appearance of minor children could have been enforced, the doctrine of virtual representation does not apply). 
ings designed to yield judicial authorization of a sale of estate property that was required by some exigency in the management of a testator's estate. One can only speculate how adequately the unborn generally were protected. Courts were wary, however, when faced with a claim of preclusion through a representative that had sought some advantage for himself. In such circumstances, when the motive, inducement, or actual position of the representative did not fully protect the absentees' interest, some courts held that the absentees were not bound. ${ }^{286}$ Other cases held more simply that where the representative had a conflict of interest there could be no bona fide contest that would bind absent class members. ${ }^{287}$

In a few of the remaindermen cases, the concept of an in rem proceeding was reintroduced. A few courts thus accepted the idea that the absentee remaindermen were bound because the proceeding bound "all the world" pursuant to service by publication. Application of the in rem concept to the claims of unborn remaindermen is a work of art in high Victorian legal doctrine. There is a certain weird consistency in the thought that nonexistent remaindermen would be adequately notified by summons of the kind published in a legal newspaper. Perhaps needless to say, treating the suit as an in rem proceeding and notice by publication as sufficient to summon an

${ }^{286}$ See Ussery v. Darrow, 188 So. 885, 890 (Ala. 1939) (following precedent indicating that virtual representation is binding unless the representative's interests are adverse to or conflicting with those of the unborn remaindermen); Swoope v. Darrow, 188 So. 879, 882 (Ala. 1939) (holding that a judgment regarding a will was not binding on nonparty descendants of the testator unless the doctrine of "virtual representation" applied); Fallon v. Superior Court, 90 P.2d 858, 859 (Cal. Dist. Ct. App. 1939) (holding that the sufficiency of representation in a class suit so as to bind the members depends on the good faith of the representative and the nature of the judgment's effect on those represented).

287 See Los Angeles County v. Winans, 109 P. 640, 647 (Cal. Dist. Ct. App. 1910) (holding that the rule as to unborn remaindermen is not applicable unless the interests of the representative and those represented are identical); Adami v. Gercken, 150 N.Y.S. 8, 11-12 (App. Div. 1914) (holding that a property judgment was not binding on plaintiffs whose sole representation of their contingent interests was by those with interests hostile to their own), aff'd, 116 N.E. 1032 (N.Y. 1917); see also Goodloe v. Woods, 80 S.E. 108, 112 (Va. 1913) (holding that a husband could not represent his wife's minor children in a proceeding because the husband's and children's interests were not identical).

Such was the situation in McArthur v. Scott, 113 U.S. 340 (1885), discussed supra note notes 271-77 and accompanying text. The Supreme Court had observed:

The only parties... who were of age and capable of representing themselves, were the heirs at law, interested to set aside the will ... . The guardian ad litem, appointed to represent the opposing interest... was... interested as an heir at law .... Each of the persons so appointed confessed ... the allegations of the bill, and in his answer as guardian neither admitted nor denied those allegations .... All the appointments[]... all the answers[] ... and the issue to the jury [were] ordered ... on one and the same day, within a week before the verdict and final decree.

Id. at 394. 
absentee obviates any question of representation of the absentees, let alone any question of adequacy of representation.

The second group of state court cases consisted of the taxpayer suits. These exhibit the contradictions found in the New York cases of an earlier period. ${ }^{288}$ Many held that taxpayer suits could be maintained as representative proceedings and that they would bind all taxpayers in the community, but many others reached the opposite conclusion on both questions. Some decisions simply held without analysis that all taxpayers are bound by the judgment in a taxpayers' suit. ${ }^{289}$ Some used the analogy to virtual representation. ${ }^{290}$ Others reasoned that if the issue involved the public interest or public right, ${ }^{291}$ common interest of citizens, ${ }^{292}$ or general interest, ${ }^{293}$ all tax-

${ }^{288}$ See supra notes 164-74 and accompanying text (discussing the earlier New York taxpayers' suits which bound all taxpayers to the suit brought by some, despite the real possibility that some members of the represented group held divergent interests).

${ }^{289}$ See Rigsby v. Ruraldale Consol. Sch. Dist., 20 S.W.2d 624, 625 (Ark. 1929) (holding that a suit to enjoin school district officers was res judicata because all citizens of a school district were bound by previous decision involving the issue presented); People ex rel. Lewis v. Whittaker, 98 N.E. 967,969 (Ill. 1912) (holding that a final judgment in quo warranto ousting a district's commissioners barred subsequent in quo warranto proceedings); Stone v. Winn, 176 S.W. 933, 940 (Ky. 1915) (holding that county taxpayers are bound by res judicata decisions against the county since a municipal corporation stands as a trustee for its citizens in suits of general interest); Green County v. Lewis, 163 S.W. 489, 492 (Ky. 1914) (holding that attomeys were entitled to percentages of unpaid bonds as previous high court ruling declaring bonds void was a binding precedent on the issue); State ex rel. Wilson v. Rainey, $74 \mathrm{Mo} .229$, 235 (1881) (holding that a judgment against a county regarding the levy and collection of a tax is a matter of general interest and therefore binding on the entire community); City of $\mathrm{El}$ Reno v. Cleveland-Trinidad Paving Co., 107 P. 163, 166 (Okla. 1910) (holding that a taxpayer may bring suit in behalf of all those "similarly situated," and thus the issue before the court was res judicata); Gallaher v. City of Moundsville, 12 S.E. 859, 860 (W. Va. 1891) (holding that there was sufficient identity of parties in a taxpayer suit to obtain an injunction against the collection of taxes to allow a defense of res judicata).

290 See McCarroll v. Farrar, 134 S.W.2d 561, 563-64 (Ark. 1939) (holding that the issue of a consumer tax on liquor, beer, and wines was res judicata, reasoning that all citizens had been virtually represented in previous suit); Crain v. St. Francis Levee Dist., 74 S.W.2d 970, 971 (Ark. 1934) (holding that a previously unnamed intervening taxpayer could join a suit as if he had been named, since the original plaintiff carried out the suit in behalf of all taxpayers as their representative); Howard-Sevier Road Imp. Dist. No. 1 v. Hunt, 265 S.W. 517, 519-20 (Ark. 1924) (holding that a taxpayer suit challenging the assessment of benefits was res judicata and that the taxpayers had already been represented in a previous case involving the same cause of action and same subject matter "of common or general interest to many persons").

${ }^{291}$ See Cannon v. Nelson, 48 N.W. 1033, 1034 (Iowa 1891) (holding that a ruling against a county in a matter of public interest was binding on all county inhabitants and that the inhabitant of the county in question was estopped from contesting the sale of a parcel of land); McEntire v. Williamson, 65 P. 244, 246 (Kan. 1901) (holding that the plaintiff, as a city taxpayer, was in privity with the city officers, and therefore any "litigation, decision, and judgment" was binding on that taxpayer); Hovey v. Shepherd, 147 S.W. 224, 225 (Tex. 1912) (holding that if the matter adjudicated was in the "interest of the public" then all citizens were bound by the decision). 
citizens, ${ }^{292}$ or general interest, ${ }^{293}$ all taxpayers would be bound. Some held that absent taxpayers were bound because such suits were in rem. ${ }^{294}$

Other cases, however, held that the legal rights of taxpayers were "individual" or "several," so that a representative suit was impermissible. For example, a taxpayer who sought to restrain all tax foreclosure sales in his school district, on the ground that the tax deficiencies were procured by fraud and forgery, was refused a representative suit on the ground that taxpayer property was owned "in severalty," and therefore the rights involved were separate and distinct. ${ }^{295}$ A suit to void a general levy to aid construction of a railroad was held to involve "several" rights and therefore to be improper on similar grounds. ${ }^{296}$ It is hard to see how the plaintiffs' situations in these cases are any different from ones in which taxpayer suits had been allowed. Disallowance of a taxpayers' suit, of course, pretermitted the question of whether such a suit would be binding in a subsequent suit seeking similar relief. In any event, the results of these cases are not an exception to the general rule in taxpayers' suits, but a contradiction of it.

The state decisions, however, increasingly came to allow citizens' and taxpayers' suits and to address the preclusion problem specifically in terms of the alignment of interests and adequacy of representation. A leading case in this vein was Lightle v. Kirby. ${ }^{297}$ In the original action, Mrs. Lightle, an

${ }^{292}$ See People ex rel. Chilcoat v. Harrison, 97 N.E. 1092, 1093 (Ill. 1912) (holding that in a suit to enforce a public right, all those citizens who constitute the public are bound by a court's ruling in the suit).

${ }^{293}$ See Clark v. Wolf, 29 Iowa 197, 202-04 (1870) (holding that a judgment against a county is binding by virtue of "common interest" on all citizens thereof, even if they were never named as defendants in the suit). It should be noted that the court in Adami v. Gercken, 150 N.Y.S. 8, 11 (App. Div. 1914), rejected the notion that absentees are bound in virtue of the fact that the action is denominated as being in rem.

${ }^{294}$ See Greenberg v. City of Chicago, 99 N.E. 1039, 1040-41 (IIl. 1912) (holding that a previous decision in a suit brought by taxpayers seeking to enforce a public right was binding on all taxpayers generally, with the question of jurisdiction "in some respects rest[ing] on the principles of a proceeding in rem").

${ }^{295}$ Newcomb v. Horton, 18 Wis. 566, 569 (1864); see also Barnes v. City of Beloit, 19 Wis. 93, 95 (1865) (holding that multiple lot owners in a city with no common pecuniary interest cannot unite in an action to bar the sale of lots owned by them severally for illegally assessed taxes). The formula relied on in these decisions is the same as that in Ayres $v$. Carver, 58 U.S. 591, 594 (1854), discussed supra in text accompanying notes 238-40, and finding that the absent parties were not represented by the defendants present because there was no "interest [n]or estate in common among these several defendants."

${ }^{296}$ See Fleming v. Mershon, 36 Iowa 413, 419 (1873) ("Persons charged severally with a tax have no such common or general interest in resisting its collection as will authorize one to sue for all."); see also Haese v. Heitzeg, 114 P. 816, 817 (Cal. 1911) (upholding the general principle that, if a suit is brought by a plaintiff "on behalf of himself and others similarly situated," the judgment is binding only on those of the class who accept representation and join the suit).

${ }^{297} 108$ S.W.2d 896 (Ark. 1937). 
owner of property abutting a state highway within a municipal improvement district, sued the commissioners of the district to require that state aid be used to reduce assessments on properties like her own that abut the highway. The suit was brought under a statute providing for tax relief in such circumstances. A later taxpayer action sought to apply the same state monies to reduce assessments on all lots that were in the same improvement district. ${ }^{298}$ Mrs. Lightle intervened in this subsequent action and cited the earlier decree in her favor to prevent judgment for the larger group of taxpayers in the improvement district. The court held that the taxpayer in the second action was not bound by the judgment in the first:

There was no community of interests. On the contrary, the interests of the parties were highly antagonistic. The controversy was between two groups of property owners, and the relief prayed and granted in the first decree was to the effect that one group of property owners should be favored and the other excluded. This was not a case in which one group of property owners could represent all, because their interests were antagonistic and irreconcilable. ${ }^{299}$

Creditors' bills, as we have seen, were among the longest established types of representative suits. ${ }^{300}$ A leading case at the beginning of the twentieth century was Guffanti v. National Surety $\mathrm{Co}^{301}$ This decision explained that when a debtor's assets were less than the total of the creditors' claims, a binding class action was not only permitted but was required; otherwise some creditors (the parties) would be paid and others (the absentees) would not. Some decisions added that a binding decree was also necessary to protect the defendant debtor from numerous lawsuits. ${ }^{302}$ Many cases used the term "common interest" to describe the position of the creditors. ${ }^{303}$

${ }^{298}$ See id. at 896 (explaining that after Mrs. Lightle brought suit against the commissioners of the district, other property owners who were not parties brought their own suit against the commissioners).

299 Id. at 897.

${ }^{300}$ See supra notes 72-91 and accompanying text (discussing creditor and legatee bills).

30190 N.E. 174 (N.Y. 1909); see also Marshall v. Sherman, 42 N.E. 419, 422 (N.Y. 1895) (holding that a creditor's right of action against the stockholders of a corporation can only be a suit in equity or by or in behalf of all the creditors against all the stockholders); Schuehle v. Reiman, 86 N.Y. 270, 273 (1881) (holding that, where creditors' actions pending in two separate tribunals to accomplish the same goal are brought in behalf of others having an interest in the fund, the proceedings may be consolidated).

${ }^{302}$ See, e.g., Kerr v. Blodgett, 48 N.Y. 62, 67 (1871) (explaining that, in suits with numerous plaintiff creditors, "when an order or decree for an accounting is once made ... it operates as an interlocutory judgment, in favor of each and every creditor ... as effectually as if he had been named and had appeared as a party"), superceded by statute as stated in In re Currier, 8 Daly 119, 120-21 (N.Y. Ct. Com. P1. 1878).

${ }^{303}$ See, e.g., Bouton v. Van Buren, 127 N.E. 477, 478 (N.Y. 1920) (explaining that a complaint for an accounting against stockholders can only be maintained if the plaintiff is a representative of a "common or general interest" of the others); Guffanti, 90 N.E. at 176, dis- 
But the court used opposite characterization where the representatives had not been "fairly selected" 304 and where absent class members might not receive "actual and efficient protection." 305 The same analysis was also applied when the question arose after the court rendered a class action judgment, where it appeared that the relief injured absentees while favoring the representatives. ${ }^{306}$ The relationship described as "common interest" may have come dimly to be recognized as a surrogate for adequacy of representation rather than as a characteristic having independent significance. ${ }^{307}$

cussed supra note 301 and accompanying text (discussing the "community of interest" among the represented plaintiffs).

${ }^{304}$ Leviness v. Consolidated Gas, Elec., Light \& Power Co., 80 A. 304, 308 (Md. 1911) (holding that a preferred stockholder's lien is dischargeable under a court decree passed in a proceeding in which "fairly selected representatives of that class are made parties"); see also Hollifield v. Wrightsville \& T.R. Co., 27 S.E. 715, 717 (Ga. 1896) (holding that a petition filed by a stockholder of a company to restrain the company from allowing votes from a second company-to whom the first company allegedly issued some of its capital stock illegally - cannot be maintained when neither the second company nor its receiver is a named defendant).

${ }^{305}$ New York State Rys. v. Security Trust Co., 238 N.Y.S. 354, 361 (Sup. Ct. 1929), aff d, 238 N.Y.S. 887 (App. Div. 1930); see also City of Detroit v. Detroit United Rys., 197 N.W. 697, 703 (Mich. 1924) (explaining that class members "are supposed to ... have one common right or one common interest, the operation and protection of which will be for the common benefit of all" (citation omitted)); cf. Davis v. Peabody, 49 N.E. 750, 751 (Mass. 1898) (holding that, if stockholders with like interests are too numerous to join, then enough of them to have the class's interests represented should be made parties).

${ }^{306}$ See Cody Trust Co. v. Hotel Clayton Co., 12 N.E.2d 32, 37 (Ill. App. Ct. 1937) (finding it sufficient to make properly represented absentees parties to a suit for partial foreclosure of a trust deed and holding that joinder was not necessary); Wiggins v. Wagley, 190 S.W. 736, 738 (Tex. Civ. App. 1916, no writ) (holding that a junior lienholder was not bound by foreclosure to which he was not a party); cf. Sherman v. International Life Ins. Co., 236 S.W. 634, 641 (Mo. 1921) (en banc), cert. denied, 262 U.S. 346 (1923) (holding that, when reorganization certificate holders asked the lower court to approve their plan for rehabilitating the company, and only acted in their own self interest, other non-consenting certificate holders were not represented).

${ }^{307}$ See, e.g., Groves v. Farmers State Bank, 12 N.E.2d 618, 624 (IIl. 1938) (holding that, where a complainant has the right to represent his class, other class members who have "common rights" are bound by the results of the case); Southern Ornamental Iron Works v. Morrow, 101 S.W.2d 336, 343 (Tex. Civ. App. 1937, no writ) (holding that a complete and final judgment by the district court, that subscribers to an association were liable to the receiver, was not subject to a collateral attack); Dewey v. Saint Albans Trust Co., 12 A. 224, 229 (Vt. 1888) (holding that a court's decision as to whether many depositors get preference over other creditors from an insolvent bank binds the whole class). 


\section{Attempts of Synthesis}

The concept of a representative suit, particularly its effects on absentees, thus remained for a century about as uncertain as Story had found it. ${ }^{308}$ Was the representative suit merely a contrivance to evade the rigors of the Necessary Party Rule, whereby it was pretended that all "numerous parties" were before the court through a representative, but wherein the judgment actually determined only the rights of those who appeared? Was the representative suit something more than this, a device for allowing supplemental joinder of additional claimants after liability had been determined-where the absentees could "come in under the decree"309 - achieving results that later became possible with abolition of the "mutuality rule"? ?10 Or did the representative suit also bind absentees when the judgment was adverse to the class, at least in some types of cases?

Whatever answers might be given to these questions, they can all be supported by many decisions and even more dicta. But how can the cases be reconciled?

Two leading commentators, Pomercy writing in 1881 and Street writing in 1909, made attempts at synthesis. Pomeroy, in his Treatise on Equity Jurisprudence, stated the problem in terms of the conditions required for exercise of equity jurisdiction in bills of peace. ${ }^{311}$ Thinking of representative suits in terms of bills of peace was the most general way of formulating the problem, for the predicate of a bill of peace is simply that "numerous bod-

${ }^{308}$ See supra notes $125-48$ and accompanying text (discussing Story's creation of class suits in his Commentaries on Equity Pleadings, and his approach to class suits as an exception to the Necessary Parties Rule).

309 STORY, supra note 74, at 96.

310 The "mutuality rule" permitted a litigant to claim the benefit of preclusion by judgment only if, had the judgment gone the other way, he would have suffered the burden of an adverse judgment. See Blonder-Tongue Labs., Inc. v. University of Ill. Found., 402 U.S. 313, 317-50 (1971) (providing an historical analysis of the mutuality rule since its adoption in Triplett v. Lowell, 297 U.S. 638 (1936), then overruling that case to the extent that it precluded an estoppel plea by a patent infringement defendant). When the mutuality rule does not stand in the way, a judgment in favor of one litigant can be used by another as a basis for precluding the losing party from relitigating issues resolved in the first suit. See, e.g., Parklane Hosiery Co. v. Shore, 439 U.S. 322, 332-33 (1979) (holding that, where a party had a "'full and fair' opportunity to litigate [its] claims in the [previous] action, the contemporary law of collateral estoppel leads inescapably to the conclusion that [the party is] collaterally estopped from relitigating the [issue]"). Upon abrogation of the mutuality rule, any case in which one of several claimants litigates successfully, is in effect potentially a representative suit as to the common issues. See RESTATEMENT (SECOND) JUDGMENTS \$§ 28, 29 (1982) (listing exceptions in which the relitigation of an issue in a subsequent action is not precluded).

3111 JOHN NORTON POMEROY, TREATISE ON EQUITY JURISPRUDENCE $§ \S 255,267-69$, 292-95 (San Francisco, A.L. Bancroft \& Co. 1881). 
ies" are involved who otherwise may generate multiple litigation. ${ }^{312}$ The bill of peace requires only that there be "numerous bodies" involved in similar issues, without regard to whatever might be the connections between the parties or the relative homogeneity of their interests. Thus, if bills of peace would lie simply where there are "numerous bodies" having controversies that involved substantial common issues, and if the decree in such a case bound absentees, then the scope of the binding representative suit was broad indeed. ${ }^{313}$

Pomeroy argued that, while early English cases seeking "technical bills of peace" may have required "privity," as of his time:

[T] he weight of authority is simply overwhelming that the jurisdiction may and should be exercised either on behalf of a numerous body of separate claimants against a single party, or on behalf of a single party against such a numerous body, although there is no "common title," nor "community of right," or of "interest in the subject-matter"... but where there is and because there is merely a community of interest among them in the questions of law and fact ... or in the kind and form of relief demanded ....

Concerning a suit by a plaintiff class, Pomeroy stated that such a suit could properly be framed where "a number of persons have separate and distinct interests, but still united by some common tie, against one determined party, and these interests may perhaps be enforced ... by one suing on behalf of himself and all the others." 315

A defendant class suit could properly be framed where "[o]ne determined party has a general right against a number of persons, common to all in some of its features, but still affecting each individually and only with re-

${ }^{312} I d$. $\$ 268$, at 292.

313 For a detailed description of the controversy about bills of peace, see ZECHARIAH CHAFEE, SOME PROBLEMS OF EQUITY 170-98 (1953), providing an historical review of "the war which has raged for the past half century between the advocates of the liberal view ... and the restricted view [of multiplicity]" and identifying Pomeroy with the former, and the followers of the Tribette case with the latter.

314 POMEROY, supra note $311, \S 269$, at 293 . Pomeroy continues in even more emphatic terms: "In a majority of the decided cases, this community of interest ... has originated from the fact that the separate claims ... arose by means of the same unauthorized, unlawful, or illegal act or proceeding. Even this external feature of unity, however, has not always existed, and is not deemed essential." Id. It should be remembered that Pomeroy had strong support for such a broad and simple definition of a class suit. The typical Code provision read as follows: "[W] hen the question is one of a common or general interest, of many persons, or when the parties are numerous, and it is impracticable to bring them all before the court, one or more may sue or defend for the benefit of all." CAL. CIV. PROC. CODE $\$ 382$ (Deering 1931) (originally enacted Mar. 11, 1872).

315 POMEROY, supra note $311, \S 255$, at 267. 
spect to his separate, distinct interests."316 Pomeroy described as follows the analytic problem posed by the relevant cases:

Is it necessary that the common bond, element, or feature should inhere in the very rights, interests, or claims themselves which subsist between the body of persons on the one side, and the single party on the other, and should affect the nature and form of those rights... to such an extent that they create some positive and recognized existing legal relation or privity between the individual members of the group...? Or, is it enough that the common bond or element consists solely in the fact that all the rights... have arisen from the same source ... event, or ... transaction, and in the fact that they all involve and depend upon similar questions of fact, and the same questions of law ...? This question lies at the foundation of the whole discussion. ${ }^{317}$

Pomeroy answered the question posed by affirming the second of these alternatives. Thus, he would have allowed and contended that the decisions permitted a class suit in all situations involving numerous parties where modern procedure authorized permissive joinder. ${ }^{318}$

Notably, in the foregoing discussion from his treatise on equity jurisprudence, Pomeroy was addressing the problem of joinder rather than res judicata. He made no mention of Equity Rule 48, with its reservation of the rights of absentees, and does not appear to have addressed the res judicata effect of the judgment in a class action. Moreover, his discussion in another treatise shows that Pomeroy evidently contemplated that the absent parties ordinarily would come in or be brought in as parties before judgment. ${ }^{319}$

At any rate, only in this latter treatise did Pomeroy address the problem of preclusion of absentees. There he said that the problem could arise in two contexts. The first was where the absentee sought the benefit of a decree in favor of the class:

[T] he question may be, whether this individual, as against the defendants in the action, and perhaps as against those who were the original plaintiffs, or who made themselves such, is entitled to the immediate benefits of the recovery, to a share in the relief granted by the court in its decree. ${ }^{320}$

${ }^{316} I d$. at 268.

${ }^{317}$ Id. at $268-69$.

${ }^{318}$ See FED. R. CIV. P. 18(a) ("A party asserting a claim to relief as an original claim ... may join, either as independent or as alternate claims, as many claims ... as the party has against an opposing party.").

319 See JOHN NORTON POMEROY, REMEDIES AND REMEDIAL RIGHTS BY THE CIVIL ACTION ACCORDING TO THE REFORMED AMERICAN PROCEDURE 460 (John Norton Pomeroy, Jr. ed., 3d ed., Boston, Little Brown \& Co. 1894) ("It is optional with [members of the represented class] whether they will become parties or not ....").

${ }^{320}$ Id. at 461 . 
Pomeroy concluded that some affirmative act may be necessary for the absentee to take advantage of the decree, that the absentee must also be willing to contribute to the expenses of the suit, and that it will often be necessary for each absentee to join as a party. ${ }^{321}$ The cases upon which Pomeroy draws make clear that he is referring to practice in creditors' bills. $^{322}$

The second context addressed by Pomeroy involved preclusion of absentees by a decree adverse to the class: "[T]he question may be whether the specified individual who is one of those represented by the actual plaintiff, is concluded and bound by the judgment rendered in the action."323

Pomeroy addressed this problem only in a cursory fashion, ignoring the confusion in the precedents, while evidently convinced that an absentee could not be bound. He concluded:

Of course he is not bound unless he was practically a party to the proceeding; the plainest principles of common justice refuse to hold a man concluded if he has not had "a day in court."... If the subsequent proceeding is a hostile one against the person, the former adjudication cannot be relied upon as an estoppel or as conclusive, unless he had affirmatively taken the steps which made him an actual party ... or unless, after having had notice, and an opportunity of coming in ... he had refused or neglected to do so. ${ }^{324}$

This conclusion obviously ignored cases such as Smith $v$. Swormstedt, holding or strongly stating that absentees were bound under some circumstances. ${ }^{325}$ To ignore such cases was at least one way, perhaps the only way, to cope with the contradictions in the decisions.

The other prominent commentator addressing the subject was Thomas Atkins Street in his 1909 treatise, Federal Equity Practice. ${ }^{326}$ Street's analysis is not as well documented as Pomeroy's, and for that matter, not as well documented as Story's. Nevertheless, his approach is more analytic and certainly more candid so far as the waverings of doctrine are concerned.

321 See id.

${ }^{322}$ See id. at 460 n.3, 463 n.1, the latter stating:

See, on this subject, Story's Eq. Pl. \$§ 99, 196; David v. Frowd, 1 Myl. \& K. 200 [39 Eng. Rep. 657 (Ch. 1833)]; Gillespie v. Alexander, 3 Russ. 130 [38 Eng. Rep. 525 (Ch. 1827)]; Farrell v. Smith, 2 Ball \& B. 337 [(Ir. H. Ct. 1813)] . .. The equity practice in this class of cases is, upon rendering the interlocutory decree, to advertise for all the represented persons to appear before a master ... and establish their claims ....

${ }^{323}$ Id. at 461-62.

324 Id. at 462 .

${ }^{325}$ See supra text accompanying notes 223, 226-28, 237-38 (discussing the holding in Smith v. Swormstedt that when a class suit is allowed as an exception to the Necessary Parties Rule, the decree is binding on all absentees).

3261 THOMAS ATKINS STREET, FEDERAL EQUITY PRACTICE 336-54 (1909). 
Street's attempt to establish a critical and logical structure added a further conceptual distinction to those laid down by Story. This distinction was later absorbed in the formulation of Federal Rule 23. 327

In Street's treatise we find the first articulation of a distinction between "true" class suits and "spurious" class suits. Under the sectional heading "True Class Suit Concerns Property," Street says the following:

[S]uits brought by or against numerous defendants are of two radically different types. In the first type, which is that of the true class suit, it will be found that the subject-matter of the suit is a fund or property over which the court can and does acquire an effective jurisdiction....

In a footnote to this statement, Street says that "Smith v. Swormstedt is a good illustration of this class of cases. ${ }^{.329}$

In the immediately following section entitled "Spurious Class Suit Founded on Personal Liability," Street says:

In the other type of cases, the suit is not concerned with a fund or property at all, but with a personal liability. Here the suit is not a class suit in any proper sense. We may call it a spurious class suit. Illustrations of this type ... are ... suits by or against involuntary associations ... or against numerous defendants to enjoin a threatened injury. Suits for injunction against strikes ... fall within this class .... ${ }^{330}$

In a footnote to this statement, Street cites American Steel \& Wire Co. $v$. Wire Drawers' \& Die Makers' Unions Nos. $1 \& 3$ and a case that relied on that decision. ${ }^{331}$

Having said this, Street goes on to deal with the binding effect of the decree in a class suit. Under the heading "Effect of Decree in Class Suits under English Practice" he says:

It has always been understood in the English chancery, and apparently in the equity courts of this country, that the decree in class suits is binding on all the persons in interest.... The true class suit in fact supplies an instance of virtual representation. When the court once gets jurisdiction over the subjectmatter, it will proceed to clean up every element of the controversy .... Those who are represented are concluded in the same degree and to the same extent as are those who are actually before the court. ${ }^{332}$

327 FED. R. CIV. P. 23.

${ }^{328} I d . \S 547$, at 342 .

${ }^{329}$ Id. $\$ 547$, at $342 \mathrm{n} .7$ (citation omitted).

${ }^{330}$ Id. $\$ 548$, at $342-43$.

33190 F. 598 (C.C.N.D. Ohio 1898), discussed supra at notes 254, 258-60 and accompanying text, and relied upon in Evenson v. Spaulding, 150 F. 517 (9th Cir. 1907).

${ }^{332}$ STREET, supra note $326, \S 549$, at 343. 
Although Street is not entirely clear as to whether this binding effect obtains only in "true" class suits, this is distinctly the implication. If so, he is to be taken as saying that there are "true" class suits and "spurious" class suits; that "true" class suits involve numerous claimants to a fund; and that the decree in such cases, and only in such cases, is binding upon the absentees. All other so-called representative suits are "spurious."

That this is his meaning is quite clear from his further discussion. Turning to Equity Rule 48, Street says:

The final clause in equity rule 48 is to the effect that "the decree shall be without prejudice to the rights and claims of all the absent parties." Just what may be the meaning of this language is not very clear....

But ... taken literally, this closing reservation is inconsistent with the English practice. ${ }^{333}$

He asks, "But what have the federal courts, and especially the supreme court, done with this reservation or proviso in equity rule 48 ?"334 He then responds:

[T] he supreme court has done the only thing that could properly be done, ... namely, it has, in true class suits, ignored the reservation ....

It results then that, as regards true class suits, the reservation in equity rule 48 cannot be given literal effect....

But .... the reservation of the equity rule is applicable in its full and literal sense... [in] the spurious class suit, the suit brought by or against numerous parties in respect of a personal liability.

Considering the distinctions between in rem and in personam proceedings that have grown up in other areas of the law, ${ }^{336}$ and considering that it had come to be held that absentee creditors were bound by the distribution decree in a creditors' bill, ${ }^{337}$ it is not surprising that Street's formulation of the preclusion rule in class actions was based upon the concept of a "fund." It is surprising, however, that he thought preclusion arose only in "fund" cases, a category that excludes some of the "association" cases. ${ }^{338}$ Of all the types of class suits, those involving the relationship of "association" had the

${ }^{333} I d . \S 550$, at 344 .

${ }^{334}$ Id. $\$ 551$, at 344 .

${ }^{335} I d . \$ \$ 551-52$, at $344-45$.

${ }^{336}$ See, e.g., Huling v. Kaw Valley Ry., 130 U.S. 559, 563-64 (1889) (holding that in an in rem proceeding where a railroad condemned the land owned by a nonresident, publication of the condemnation, although not actual notice, is sufficient).

${ }^{337}$ See In re Reese, 107 F. 942, 945-46 (8th Cir. 1901) (holding parties liable for willfully violating an injunction though they had not been party to the injunction at its creation).

${ }^{338}$ See sources cited supra notes $49,111-16,222-32$ and accompanying text. 
firmest basis for binding absent members, as is demonstrated notably by the aforementioned statement in Swormstedt. ${ }^{339}$

Be that as it may, Street's analysis attempted to link the preclusive effect of a class suit decree to a typology he sought to impose on the cases. On one hand, according to Street, the type of class suit involving a "fund" was a "true" class suit in which the decree bound absentees. On the other hand, a class suit not involving a "fund" was a "spurious" class suit in which the decree did not bind absentees. This synthesis ignored the fact that in some leading cases which could be said to involve a fund, the decree had been held not binding on absentees, ${ }^{340}$ and that the decree had been held binding in some leading cases that did not involve a fund. ${ }^{341}$

Beyond relying on his typology of class suits to differentiate binding effects of the decree, Street attempted to explain class suit preclusion under "English Practice" on the basis of adequacy of representation:

It is obvious that the court, before proceeding against parties who are such by representation only, will take care to see that all are properly and fairly represented. This has always been fully insisted on.... The jurisdiction of the court ... enables the court to determine the rights of all persons ... provided only they are sufficiently represented before the court. ${ }^{342}$

If we juxtapose Pomeroy and Street, we see that both had difficulty with the problem of preclusion, and that each endeavored to establish criteria for class suit preclusion in terms of the type of case. In terms of representative and preclusive actions, Street invented the terms "true" and "spurious," which those already familiar with the subject know came to have a later life in class suit doctrine. ${ }^{343}$ But neither Pomeroy nor Street could satisfactorily explain the cases.

\section{The 1912 Revision of the Federal Equity Rules}

In 1912, the Federal Equity Rules were revised. The revision, which also renumbered the Rules, provided for class actions in Rule 38 as follows:

${ }^{339} 57$ U.S. 288, 302 (1853) (establishing that suits can be filed against representatives of associations in behalf of the associations themselves "without requiring joinder of all the association's members").

${ }^{340}$ See, e.g., McArthur v. Scott, 113 U.S. 340, 394-95 (1885) (stating that a "decree must be without prejudice to the rights of those who are not made parties, and who do not come in before the decree").

${ }^{341}$ See, e.g., In re Lennon, 166 U.S. 548, 554 (1897) (asserting that actual notice of the injunction is insufficient to bind absentees who were not served with process, subpoena, or the injunction itself).

342 STREET, supra note $326, \S 549$, at 343.

343 See FED. R. CIV. P. 23 (as adopted in 1938); see also 2 JAMES WM. MOORE \& JOSEPH FRIEDMAN, MOORE's FEDERAL PRACTICE $\$ 23.07$ (1938). 
"When the question is one of common or general interest to many persons constituting a class so numerous as to make it impracticable to bring them all before the court, one or more may sue or defend for the whole." ${ }^{344}$ This language substantially tracked old Rule 48 with one crucial change-the reservation of absentees' rights in old Equity Rule 48 was excised in the new version.

There appears to be very little legislative history of this revision. The only legislative history we have found explains that the new rule was based on the then New York Code of Civil Procedure Section 448, which was essentially the same as the original provision. ${ }^{345}$ That section permitted class suits on the basis of a "common question."346 In a monograph by Hopkins concerning the 1912 revision, it was explained that the reservation of the rights of absent class members had been deleted from old Equity Rule 48 because "in every true 'class suit' the decree is necessarily binding upon all parties included in the decree." Bar Committee of the Circuit Court of Appeals of the Second Circuit, along with the decisions in Coann ${ }^{348}$ and American Steel \& Wire Co., ${ }^{349}$ as authority for his interpretation of the history of the revision embodied in Rule $38 .{ }^{350}$

If reliance was placed on Coann and American Steel \& Wire in the revision of Rule 38, the revised rule poses interesting problems of interpretation. The court in Coann flatly held that absentees were not precluded, while the court in American Steel \& Wire held that the reservation in old Equity Rule 48 prevented preclusion of absent class members unless they were joined in supplemental proceedings. Reference to these cases by the revisers drafting the 1912 Rules thus appears to imply that the language of old Equity Rule 48 of itself did not prevent preclusion of absent class members. This could be responsive to the fact that Smith $v$. Swormstedt stood for the proposition that absentees could be bound notwithstanding the language

344 RULES OF PRACTICE FOR THE COURTS OF EQUITY OF THE UNITED STATES Rule 38, at 11 , reprinted in 226 U.S. 627, 659 (1912) (repealed 1938).

${ }^{345}$ See N.Y. CODE CrV. PROC. $\$ 448$ (Gilbert's ed. 1910).

And where the question is one of a common or general interest of many persons; or where the persons, who might be made parties are very numerous, and it may be impracticable to bring them all before the court, one or more may sue or defend for the benefit of all.

Id.

${ }^{346}$ Compare the substantially similar California version, quoted supra at note 314 .

347 JAMES LOVE HOPKINS, THE NEW FEDERAL EQUITY RULES 240 (Byron F. Babbitt ed., 8th ed. 1933) (citation omitted).

348 14 F. 4 (C.C.N.D. Ga. 1882).

34990 F. 598 (C.C.N.D. Ohio 1898).

${ }^{350}$ HOPKINS, supra note 347 , at 240. 
of the Equity Rule. ${ }^{351}$ This in turn implies a supposition by the revisers that the binding effect of a class suit decree depends on something outside the Equity Rule, and this could be the thought underlying the 1912 revision. Such a resolution of the language of the rule, however, did not address the rest of the problem-while new Equity Rule 38 no longer prevented preclusion of absentees, did the 1912 revision permit the decree in a class suit to be binding on absentees in every case? If so, why? If not, what was the distinction between suits in which absentees were bound and those in which they were not? Some kind of answer was yet to be worked out.

\section{FROM BEN-HUR TO HANSBERRY}

Supreme Tribe of Ben-Hur v. Cauble $e^{352}$ and Hansberry v. Lee $e^{353}$ together are taken to stand for the proposition that a judgment in a class suit, whether favorable or adverse, binds absent members of the class. ${ }^{354}$ Hansberry states the added requirement that the class be adequately represented and that it cannot be adequately represented by spokespersons who have interests in conflict with those whom they purport to represent. The proposition that absentees can be bound is presupposed, however, in both decisions. The doctrinal significance of these two cases derives from their breadth of language, not from their facts or their analyses. Hansberry on its facts did not concern a prior class suit as conventionally defined. In any event, the Court in Hansberry held that the prior adverse judgment, alleged to be binding, lacked conclusive effect because the absentees' rights had not been adequately represented. Thus, it is not a holding that a class suit can bind absentees. Ben-Hur indeed meant that absentee members of a class were bound by a prior judgment, but the issue before the Court was one of

35157 U.S. 288, 302 (1853) (asserting that the decree in a class suit was binding on absentee parties as long as the representatives fairly represented the interests of the absentee parties).

352 255 U.S. $356(1921)$.

353311 U.S. 32 (1940).

354 See RESTATEMENT (SECOND) JUDGMENTS § 41, at 393 (1982) (stating that a person represented by a party to an action is bound by the judgment as though he were a party to the action himself); JACK H. FRIEDENTHAL ET AL., CIVIL PROCEDURE $\S 16.8$, at 756 (1985) (stating that "if all the requirements and prerequisites for a class action have been satisfied, the resulting decree will be binding on all class members whether they actually participated in the case or not"); see also Hitchman Coal \& Coke Co. v. Mitchell, 245 U.S. 229, 261-62 (1917) (underscoring the importance of the 1912 revision). In Hitchman, the Supreme Court held that an absentee class member could not be bound inasmuch as the case had been decided under the old Equity Rule 48. Cf. Arthur John Keeffe et al., Lee Defeats Ben Hur, 33 CoRNELl L.Q. 327, 337-39 (1948) (arguing that after Hansberry v. Lee, it is not clear that judgments in a class suit bind absent members of the class and recommending a requirement that notice be given to all members of the class for judgments to bind absent members). 
jurisdiction rather than res judicata. The fact that Ben-Hur involved a jurisdictional issue may explain why the Court held that the earlier decree was binding but failed to give attention to the character of the relationships among the members of the class before it. ${ }^{355}$ In any event, the opinion in Ben-Hur only hints at a rationale for binding the absentees and, indeed, alludes to several different rationales.

\section{A. Supreme Tribe of Ben-Hur v. Cauble}

The Supreme Tribe of Ben-Hur was a fraternal benefit association, a distinctive kind of mutual life insurance company, organized under the laws of Indiana. The facts of the case are presented in the Supreme Court's opinion as follows. ${ }^{356}$

The Tribe had been formed years before with the purpose of providing death benefits to beneficiaries from a fund of assessments paid by members. Over time, the membership grew older, and assessments accelerated while membership stagnated-young potential members were unwilling to join only to pay benefits to widows of their elders. In 1908 the Tribe, claiming imminent bankruptcy, divided its membership into two classes, thereby creating a new class of membership amounting to a distinct association. ${ }^{357}$ Present members of the Tribe would continue as Class A, but all future members would belong to Class B. The two classes would pay for their life insurance at different rates, their "mortuary funds" would be kept separate, and benefits to members of each class would be paid only out of the funds of that class. Members of Class A were authorized to transfer to Class B, but only if they agreed to pay the Class B rate of assessments. ${ }^{358}$

In 1913, five years after the reorganization was effected, George Balme, a citizen of Kentucky, and 523 other plaintiffs who lived outside of Indiana - all of them being members of the association or their beneficiariesbrought a class action suit under federal diversity jurisdiction in the United States District Court for Indiana. Balme's class suit, in behalf of the mem-

355 See fleming James, JR. \& Geoffrey C. Hazard, Civil Procedure 567 (3d ed. 1985) (noting the Court's inattention to the character of the relationship between class members in Ben-Hur, and placing the case's holding in historical context).

${ }^{356}$ See Ben-Hur, 255 U.S. at 357-63. The details of the reorganization, as described in another suit attacking the reorganization, are slightly different. See Case v. Supreme Tribe of Ben Hur, 184 N.W. 75, 76-77 (Neb. 1921) (noting that members transferring from Class A to Class $B$ were not required to pass medical examinations as if they were new members). The discrepancies, however, appear unimportant.

${ }^{357}$ See Ben-Hur, 255 U.S. at 358 (stating that the lower court established the Tribe's right to create a new class of benefit holders with a "seperate [sic] and distinct" mortuary fund).

${ }^{358}$ See id. (establishing that the lower court affirmed the right of the Tribe to authorize members of Class A to transfer to Class B). 
bers remaining in Class A, challenged the Tribe's reorganization on the ground that it was ultra vires and in violation of vested contract rights. The decree in the ensuing litigation sustained the reorganization, that is, was adverse to the plaintiff class. Thereafter, in 1919, Aurelia Cauble and certain other members of Class A, this time all citizens of Indiana, brought another class suit in Indiana state courts, again challenging the same reorganization.

Appreciation of the distinctive character of fraternal benefit associations reveals what the lawsuits were about and what Ben-Hur does-and does not-have to say about the res judicata effects of class suits generally. Fraternal benefits were different from conventional life insurance companies, in that by statute they were "required to make sufficient assessments at the rates named in their certificates to meet death losses as they occur[red]," but they were not required to accumulate funds beyond those required to pay current losses, and "such associations [would] not be considered insolvent unless the mortuary funds in the hands of the supreme officers [were] less than the death claims outstanding against the association. 359 They were meant to be "the poor man's life insurance companies, [furnishing] a cheap and simple substitute for life insurance. ${ }^{360}$ The problem was that fraternal benefit associations furnished insurance too cheaply, for they failed to calculate their costs of insurance correctly. ${ }^{361}$ It did not seem important for them to do so, because it simply was assumed that their memberships would continue to regenerate-as present members grew older, younger members would join, leaving the average age and the average rate of mortality unchanged. ${ }^{362}$ If death losses were higher than expected, then assessments would be increased to meet them.

359 IND. CODE ANN. $\S \S 5043,5044$ (Bobbs-Merrill Co. 1908).

${ }^{360} 1$ FredERICK H. BACON, A TREATISE ON THE LAW OF LIFE AND ACCIDENT INSURANCE $\S 12$ (4th ed. 1917).

${ }^{361}$ Benefits and assessments are not mentioned in Ben-Hur. Another litigation concerning the Supreme Tribe of Ben-Hur, Case v. Supreme Tribe of Ben Hur, 184 N.W. 75, 75-76 (Neb. 1921), explains the problem. When Benjamin Case joined the Tribe in 1901 at age 54, he obtained a $\$ 500$ benefit certificate and was assessed one dollar each month (or $\$ 12$ each year). If he lived to age 75 he would have paid in only $\$ 252$, half the value of his certificate. For the same one dollar a month, someone joining the Tribe in 1901 between the ages of 18 and 25 received a $\$ 1500$ benefit certificate. By the time such a person reached 75 , he would have paid in between $\$ 600$ and $\$ 684$, or 40 to $45 \%$ of the value of the certificate. Since the assessments were used to pay current death losses, interest did not accrue on them. See id. The resemblance to the financing of our federal social security system may be noted.

${ }^{362}$ See, e.g., Tusant v. Grand Lodge AOUW, 163 N.W. 690, 697 (lowa 1917) (holding that a statutory fraternal mutual benefit association possessed no power, after its organization, incorporation, and receipt of members, to change the nature of its insurance without consent of those members adversely affected, voiding a later by-law that created two classes of membership as legally unreasonable). 
Every mutual benefit association was thus a kind of Ponzi scheme that could continue in apparent financial health only so long as sufficient numbers of new members continued to join. When the associations stopped adding new members the hard fact of arithmetic confronted them:

If one hundred men mutually agree to pay each other $\$ 1,000$ at death, the $\$ 100,000$ must be gathered from the promisors if all are to be paid. Adding a member to the one hundred does not change the situation, for with each additional member there comes an additional obligation to pay $\$ 1,000$ to his beneficiaries. While the one hundred and first man mutually agrees to help pay the death losses of the one hundred, each of the one hundred has his obligations increased by the addition of such new member, and if there be not contributed enough to pay all, it but postpones the evil day to add to the membership. The theory for so many years adopted by fraternal benefit associations, that the society would continue solvent indefinitely by the addition of new blood, is as fallacious as that of the merchant who thought he could succeed by selling goods below cost if he only sold enough of them. ${ }^{363}$

In undertaking the 1908 reorganization, the officers of the Supreme Tribe of Ben-Hur had confronted this fact. The reorganization isolated the existing members in Class A. Insurance for this group ceased to be inexpensive because it would no longer be subsidized by new members who were put in Class B. The lawsuits by Balme and Cauble-the litigants whose relationship was in issue in the Ben-Hur case before the Supreme Court-were only two in a flood of such suits against various fraternal benefit associations. These suits typically challenged the right of the associations to raise assessments to pay death benefits as their memberships grew older and to cancel certificates when members failed to pay the increased assessments. The apparent unfairness of the increases, together with the sheer numbers of members involved, virtually assured courts that the same issues would be litigated and relitigated. As a result, courts were obliged to decide whether a prior judgment in a class suit barred a later suit by someone not actually a party to the judgment.

This was the issue in Ben-Hur-whether the prior decree sustaining the reorganization was binding on members who had not participated, by intervention or otherwise, in the litigation leading to that decree. The Court in

The essential principle upon which [such] associations... [are] based is that there will be a constant invigoration of the association by the accession of new members; ... and that every member of the association will be given the benefit of the average mortality of the entire membership in force at the last death prior to an assessment, resulting from this constant addition of new members.

Id. at 697 (quoting Benjamin v. Mutual Reserve Fund Life Ass'n, 79 P. 517, 520 (Cal. 1905)). The Supreme Court of Iowa was unable to see why an association operating on that principle "should not have prospered indefinitely." Id. at 695.

${ }^{363}$ Jenkins v. Talbot, 170 N.E. 735, 745-46 (Ill. 1930), appeal dismissed sub nom. McKissick v. Talbot, 283 U.S. 782 (1931). 
Ben-Hur announced that "the decree when rendered must bind all of the class properly represented." ${ }^{364}$ In its analysis, the Court cited Smith $v$. Swormstedt, which, we have seen, was a joinder case and not a res judicata

364255 U.S. 356,367 (1921). In its description of the original proceedings, the Supreme Court stated that the ancillary bill alleged that the questions decided in the original decree determined the following:

(1) The right of the Supreme Tribe of Ben-Hur to create a new class of benefit certificate holders known as Class B. (The membership in such society up to July 1 , 1908, having been in the class thereafter to be designated as Class A.) (2) The right of the society to determine that all benefit certificates issued after July 1,1908 , should be Class B certificates, and that no Class A certificates should be issued after that date, and no new members taken into Class $A$, from that time. (3) The right of the Supreme Tribe of Ben-Hur to require members of Class B to pay different rates for their insurance from members of Class A. (4) The right of the Supreme Tribe of Ben-Hur to require that the mortuary funds of the two classes be kept separate and distinct, and that the death losses occurring therein, should be paid out of the funds of each class respectively. (5) The right of the Supreme Tribe of Ben-Hur to authorize members of Class $A$ to transfer, upon a written application therefor to Class B, and to take with them into Class B their interest in the mortuary, and other funds, of the society, created, or arising prior to July 1, 1908, and requiring the Class $B$ members to pay a monthly payment and rate in excess of that paid by Class A members. (6) The right of the Supreme Tribe of Ben-Hur to require members remaining in Class A, and not transferring to Class B, to pay a sufficient number of monthly payments, or assessments, to meet the death losses in Class A. (7) The right of the Supreme Tribe of Ben-Hur to use the expense fund of the society for the purpose of creating Class $\mathrm{B}$, and induce Class $\mathrm{A}$ members to transfer to Class $\mathrm{B}$, and to secure new members in Class B. (8) Whether the Supreme Tribe of Ben-Hur had used the expense fund in a manner justified by its constitutional by-laws and a general examination of expenditures which had been made by that society, out of its expense fund, and the purpose for which these expenditures had been made, and whether any of them were made in violation of the rights of Class A members. (9) The right of the Supreme Tribe of Ben-Hur to use its expense fund, including all questions as to whether payments made out of it were equitable and just, or inequitable, wrongful and unlawful; and the question of whether the maintenance of a general expense fund, and the payments of the entire expenses of the society therefrom, was fair, just and legal. (10) Whether the Supreme Tribe of Ben-Hur had wrongfully, or unlawfully inaugurated a campaign to persuade and induce the members of the society belonging to Class $\mathrm{A}$ to give up their certificates in Class $\mathrm{A}$, and to apply for and procure membership and certificates in Class B; or whether the action of the society, and its officer in that connection, was rightful, just and equitable. (11) The question of whether the rates in Class A, in effect prior to July 1,1908 , were adequate, or inadequate, or whether they were sufficient to provide for the current death losses in Class A, and the expenses of the society; or whether it was necessary, in order to prevent the insolvency of the Supreme Tribe of Ben-Hur, to create a new class, and induce the members of the old class, in so far as it was possible to induce them, to transfer to the new class, and the right of the society to take all action necessary for this purpose.

Id. at 358-59. 
case. $^{365}$ The Ben-Hur Court also cited a leading creditors' bill decision, ${ }^{366}$ in which the claiming creditors had intervened. The difference is notable because intervention involves actual participation, not vicarious representation, and hence the case did not present the question of preclusion against absentees in its discussion of equity jurisdiction. In this discussion, the BenHur Court cited Street's treatise on federal equity practice. ${ }^{367}$ Finally, the Court cited two decisions that involved the preclusive effects of class suit decrees in fraternal benefit cases-Supreme Council of the Royal Arcanum v. Green ${ }^{368}$ and Hartford Life Ins. Co. v. Ibs, ${ }^{369}$ both decided six years earlier. In these cases, the Supreme Court indeed held squarely that absent members of the class were bound by an adverse judgment in a prior class suit. ${ }^{370}$ The Court did so, however, on grounds intimately dependent on, if not peculiar to, the relationships involved in fraternal benefit associations. The facts of Green and Ibs did not support the expansive language of the Court's opinion in Ben-Hur.

In Green, the certificate of a member of a fraternal benefit association was canceled when he refused to pay increased assessments levied against him because of an increase in death losses. He sued the association, claiming that the increased assessments had been unwarranted and the cancellation invalid. ${ }^{371}$ Ibs involved a similar situation, except that the plaintiff was the beneficiary under a canceled certificate, and the defendant was a life insurance company with a "mutual assessment plan" rather than, strictly speaking, a fraternal benefit association. ${ }^{372}$ In both cases, defendants answered that the increased assessments had been upheld in earlier class suits filed in their respective states of incorporation and that plaintiffs were

${ }^{365}$ See id. at 363 (citing Smith v. Swormstedt, 57 U.S. 288, 302, 16 How. 307, 322 (1853)) (relying on Smith $v$. Swormstedt for the proposition that "[c]lass suits have long been recognized in federal jurisprudence").

${ }^{366}$ See id. at 365 (citing Stewart v. Dunham, 115 U.S. 61,64 (1885)) (holding that the intervention of the co-complainants who were creditors from the same state as the defendants did not oust the jurisdiction of the federal court).

${ }^{367}$ See id. at 366 (citing STREET, supra note 326, $\$ 549$, at 343, discussed supra notes 326-30, 332-35 and accompanying text) (explaining Street's distinction between "true" and "spurious" class suits and his implication that prior class suit judgments should have a binding effect on absentees only in the "true" class suit situations).

368237 U.S. 531 (1915).

369237 U.S. 662 (1915).

${ }^{370}$ See Ibs, 237 U.S. at 672 ("The decree in such a suit [one with absent class members joined by a common interest] would be binding upon all [the members of the class]."); Green, 237 U.S. at 543-44 (explaining that the same doctrines that bind absent stockholders under a decree against a corporation bind the class members at issue in this case).

${ }^{371}$ See Green, 237 U.S. at 537 ("Green ... commenced ... assailing the validity of the increase in the rate of assessment.").

${ }^{372}$ See Ibs, 237 U.S. at 665. 
bound by those judgments. The plaintiffs insisted that they could not be bound because they had not been parties to the earlier suits. The Supreme Court disagreed in both cases, holding that the prior judgments were conclusive. $^{373}$

The crucial point in Green appeared to be that the members of a fraternal benefit association authorized the association's officers to determine the rates at which members would be assessed, and thus, the members were bound to pay whatever assessments were levied so long as the assessments did not exceed the power of the association. The Court, applying conventional corporate law doctrine, held that only a court of the state in which the organization was incorporated could decide internal management issues such as the validity of the challenged assessments. ${ }^{374} \mathrm{~A}$ decree in such a suit bound all of the corporation's members by virtue of the corporation's right to stand in judgment for its members on such issues. ${ }^{375}$

The Court's application of traditional corporation law to fraternal benefit associations obscured a crucial difference between the two kinds of organizations. The typical corporation case involved a conflict between creditors, on the one hand, and the corporation on the other. In the typical fraternal benefit case, by contrast, members of the corporation were contesting actions of their own officers. To hold that the corporation could represent its members in the latter situation was to elevate form over substance and required an almost willful denial of the serious problems of intragroup conflicts of interests.

In $I b s$, the members of the company's mutual assessment plan were not actually members of the corporation, so the Court was obliged to go further to impose preclusion. It was clear to the Court that, as in Green, the law of the state in which the company was incorporated should govern the dis-

${ }^{373}$ See Ibs, 237 U.S. at $672-73$ (holding that a prior decree in an insurance company case was conclusive in a subsequent proceeding); Green, 237 U.S. at 543-44 (holding that similar prior judgments would be conclusive in the context of corporation law, that if corporate law doctrine was applicable it would be conclusive in this case, and that the corporate law doctrine was applicable).

${ }^{374}$ The Court argued that to hold otherwise would risk the destruction of fraternal benefit associations, because "an assessment which was one thing in one State and another in another, and a fund which was distributed by one rule in one State and by a different rule somewhere else, would in practical effect amount to no assessment and no substantial sum to be distributed." Green, 237 U.S. at 542; cf. Order of United Commercial Travelers v. Wolfe, 331 U.S. 586,625 (1947) (holding that the Constitution required a state to give full faith and credit to the public acts of another state under which a fraternal benefit society was incorporated and to respect the constraints of the society's constitution within the state of incorporation).

${ }^{375}$ See Green, 237 U.S. at 543-44 ("[A] decree against the corporation ... binds the stockholder although he be not a party in a personal sense, because by virtue of his subscription to stock there was conferred on the corporation the authority to stand in judgment for the subscriber as to ... general questions."). 
pute, ${ }^{376}$ but a different analysis was required on the issue of the prior judgment's preclusive effect. The Ibs Court, citing Swormstedt, held that the plaintiff was bound by the prior class suit judgment because the class representatives "had an interest that was, in fact, similar to that of the other members of the class, and that it was impracticable for all concerned to be made parties."377

Aside from the fact that Swormstedt was a joinder and a res judicata case, the assumption of common interest among the class members was much more plausible in Swormstedt than in Ibs. In Swormstedt, there were two classes with clearly conflicting interests, each of which constituted a preexisting association. ${ }^{378}$ In $I b s$, there was a preexisting association, but it was clear that its members did not have common interests in the disputed matter. Otherwise, there would have been no lawsuit. The Court never considered the possibility that there were, in fact, two classes among the members of the mutual assessment plan-those who supported the plaintiffs and those who did not. In Ibs itself, that probably did not matter, because the insurance company in effect represented the interests of those members who approved of the changes. In failing to recognize that this fact alone made its reliance on Swormstedt's language plausible, the Court set the stage for the sweeping use to which that language was put in Ben-Hur. ${ }^{379}$

As noted earlier, the narrow issue for decision in Ben-Hur was jurisdictional. Aurelia Cauble argued that, whatever binding effect Balme's earlier class suit might have had on non-Indiana residents, she was not bound because her Indiana citizenship would have defeated the federal court's diversity jurisdiction had she been an actual party to the suit. To decide the issue, the Court first had to hold that the class suit by Balme was a proper one, that, apart from the diversity problem, could bind absentees. The Court found that issue easy: "That a class suit of this nature might have been maintained in a state court, and would have been binding on all of the class,

${ }^{376}$ The Ibs Court reasoned that the members of the mutual assessment plan were "analogous to ... shareholders ... or beneficiaries ... of trust property in the hands of the Company, as Trustee, in the State of Connecticut," the state in which the company was incorporated. Ibs, 237 U.S. at 671 . Their status thus was for the courts of Connecticut to decide, because Connecticut courts had jurisdiction to decide all questions concerning the internal affairs of the corporation. The Court also emphasized, as it had in Green, the havoc that would result from permitting different sets of rules to govern the rights and obligations of plan members in different states. See id. at 670-71 (explaining that such treatment "would have been destructive of [plan members'] rights in the plan').

${ }^{377}$ Id. at 672 (citing Swormstedt, 57 U.S. (16 How.) 288, 303 (1853)).

${ }^{378}$ See Swormstedt, 57 U.S. at 299-300, 16 How. at 319-20.

${ }^{379}$ See Ben-Hur v. Cauble, 255 U.S. 356, 363 (1921) (quoting and relying upon the language of Swormstedt for the proposition that "[c]lass suits have long been recognized in federal jurisprudence"). 
we can have no doubt. ${ }^{9380}$ As the only two authorities cited for this proposition were Green and Ibs, the "nature" of the class suit to which the Court referred was not simply representative, but it involved a fraternal benefit association. Apparently because of the distinctive nature of these class suits, the Court confidently asserted that the "rights [of Mrs. Cauble and her class] were duly represented by those before the [federal] court .... Being thus represented, we think it must necessarily follow that their rights were concluded by the original decree."

This decision represents a significant shift from the analysis in Green. As the Court saw things in Ben-Hur, Aurelia Cauble and her class were represented by George Balme and his class, not by the officers of the Tribe. ${ }^{382}$ This avoided the implausible assumption that the association's officers could represent the interests of all absent members in a dispute over the legality of action taken by the officers themselves. This analysis, however, avoided the problem of adequacy of representation rather than addressing it. Just as it had in Ibs, the Ben-Hur Court ignored the possibility that there were conflicts of interest among the members of the association. ${ }^{383}$

These problems of preclusion were obscured by the fact that the binding effect of the previous class suit was merely a preliminary matter to the main issue in the case, the jurisdictional problem. The Supreme Tribe had sought an injunction from the federal court in Indiana to restrain Aurelia Cauble's state court action on the ground that she was precluded by the earlier decree. The federal trial judge denied the injunction, ruling that Mrs. Cauble and her class were not bound by the prior decree because diversity would have been destroyed if she had been a party to the earlier suit. ${ }^{384}$ In ruling this way, the trial judge was trying to resolve an anomaly in the 1912 revisions to the

380 Id. at 366.

381 Id.

${ }^{382}$ See id. at 367 ("The parties bringing the suit [George Balme and his class] truly represented the interested class.").

${ }^{383}$ See Keeffe et al., supra note 354, at 338.

Is it conceivable that every one of the 70,000 Class A members ... desired to have the Tribe's officers enjoined from proceeding with the planned reorganization? It would seem more than likely that some of the class wished the Tribe's finances to be on a sound basis even if it might cost them some loss of benefits or standing relative to other classes of membership of the Tribe. At any rate, it seems fallacious to assume without inquiry that 70,000 people agreed, even in general, with the representatives who brought the suit.

Id.

${ }^{384}$ See Ben-Hur, 255 U.S. at 364 ("[T]he District Court held that the Indiana citizens were out of the jurisdiction of the federal court ... and that their joinder would have ousted the jurisdiction of the court, although that fact would not prevent the court from proceeding... without prejudice to their rights."). 
Federal Equity Rules. As noted earlier, ${ }^{385}$ the 1912 revisions deleted from new Rule 38 the provision in old Rule 48 that preserved the rights of absentees in class suits. The Necessary Parties Rule, as reformulated in new Rule 39 of the 1912 Equity Rules, provided, however, as follows:

In all cases where it shall appear... that persons, who might otherwise be deemed proper parties to the suit, cannot be made parties ... because their joinder would oust the jurisdiction of the court ... the court may ... proceed in the cause without making such persons parties; and in such cases the decree shall be without prejudice to the rights of the absent parties.

Rule 39 thus retained a proviso substantially similar to the one that had been dropped from Rule 38. The trial judge evidently viewed the federal class action by Balme as a necessary parties case, albeit also a class suit, and believed that Mrs. Cauble therefore was not bound by the earlier decree and was free to relitigate the issues that had been decided in that decree. ${ }^{387}$

The Supreme Court rejected this conclusion, asserting that "Rule 39 does not apply to a subject already specifically covered in Rule 38.",388 There is no direct support for this statement in the text of the Equity Rules themselves or in the little existing legislative history. On its face, the trial court's contrary opinion was just as plausible. The Court advanced two arguments in support of its conclusion. First, echoing concerns expressed in Green and $I b s,{ }^{389}$ Justice Day noted that:

[I]f the Indiana citizens are not concluded by the decree, and all others in the class are, this unfortunate situation may result in the determination of the rights of most of the class by a decree rendered upon a theory which may be repudiated in another forum as to a part of the same class. ${ }^{390}$

${ }^{385}$ See supra notes 344-49 and accompanying text (noting the deletion of old Rule 48's reservation of absentee's rights from the new Rule 38 in the 1912 revisions).

${ }^{386}$ RULES OF PRACTICE FOR THE COURTS OF EQUITY OF THE UNITED STATES Rule 39, reprinted in 226 U.S. 627, 659 (1912) (repealed 1939).

${ }^{387}$ See Ben-Hur, 255 U.S. at 362-64 (noting the district court's conclusion that "although the original bill was a class suit, the class did not include Indiana citizens [such as Mrs. Cauble]").

388 Id. at 366.

389 See Hartford Life Ins. Co. v. Ibs, 237 U.S. 662, 670-71 (1915) discussed supra at notes 374,376 (stating that "[i]t would have been destructive of [the members'] mutual rights in the plan of Mutual Insurance to use the Mortuary Fund in one way for claims of members residing in one state and to use it in another way as to claims of members residing in a different state"); Supreme Council of the Royal Arcanum v. Green, 237 U.S. 531, 542 (1915) (stating that "[t]he contradiction in terms is apparent which would rise from holding ... that there was a collective and unified standard of duty and obligation on the part of the members themselves and the corporation, and saying ... that the duty of members was to be tested isolatedly and individually ... by applying many divergent, variable and conflicting criteria").

${ }^{390}$ Ben-Hur, 255 U.S. at 366-67. 
The Court itself, however, admitted that "mere considerations of inconvenience" could not confer jurisdiction on a federal court. ${ }^{391}$

Second, Justice Day cited Stewart v. Dunham. ${ }^{392}$ As our previous discussion has shown, that case, involving a creditors' bill, held that a federal court could exercise ancillary jurisdiction over nondiverse creditors who intervened in the suit before distribution was made. The rationale of that case, however, was that the court had control of a fund and that other claimants were permitted to intervene to protect their interest in the fund. ${ }^{393}$ In fraternal benefit cases, by contrast, the issue was not how a limited fund should be distributed among various claimants, but whether the claimants themselves should be compelled to increase their contributions to meet their mutual obligations. Put differently, the members' obligations, not their rights, were at issue and would not be threatened by a distribution of a fund. Accordingly, the Court in Ben-Hur would not necessarily have denied nondiverse claimants a remedy if it held them not precluded by the prior federal decree.

The more fundamental point is that in Stewart the nondiverse claimants actually intervened in the original action, whereas in Ben-Hur, they did not. Stewart therefore was not authority for the effect of a representative suit because it involved parties who actually participated. To apply the reasoning of Stewart to Aurelia Cauble and her class was to fail to come to terms with the distinct and more difficult issues raised when a judgment is used to bar absent members of a class in subsequent litigation. In terms of the governing Equity Rules of 1912, the omission of the final clause from Rule 38 clearly meant that the Rule no longer prevented a prior class suit judgment from binding absentees. Neither, however, did the revised Rule-especially when read in conjunction with Rule 39-state or necessarily imply that absentees would be bound, as a matter of law, in every case. The only way the Court could decide that there was preclusion was by collapsing the res judicata question into the joinder question, which is precisely what it did.

The sweeping language of the Ben-Hur opinion on the issue of res judicata is comprehensible, then, only in the context of its resolution of the jurisdictional issue. When the Court stated, "[i]f the federal courts are to have the jurisdiction in class suits to which they are obviously entitled, the decree

391 Id. at 366.

392 See id. at 365 (citing Stewart v. Dunham, 115 U.S. 61, 64 (1885)) (citing the principle in Stewart v. Dunham that the federal court could exercise ancillary jurisdiction over nondiverse complainants intervening in the original suit).

393 See Stewart, 115 U.S. at 64 (reasoning that since the bill of complaint was filed by the original plaintiffs in behalf of themselves and other creditors so choosing to participate in the litigation, "the court, in exercising jurisdiction between the parties, could incidentally decree in favor of all other creditors coming in under the bill"). 
when rendered must bind all of the class properly represented, "394 the conditional structure of the statement concealed the Court's true concern-that federal class actions founded on diversity should be permitted to proceed by looking only to the citizenship of the class representative. If establishing that proposition required binding absentee members in any later action, the Court seemed prepared to accept that as a general proposition true for all class suits. The fact that this proposition was derived from a series of suits involving a very peculiar kind of association, with characteristics not likely to be found in other kinds of class suits, was simply ignored.

A final difficulty with the Court's analysis in Ben-Hur concerns its relationship with the typology proposed by Street and the possible incorporation of that typology into Rule 38 of the Equity Rules of 1912. The Court assumed in Ben-Hur that Balme's original suit was a class suit within the meaning of Rule $38 .^{395}$ As discussed earlier, the revisers of the Equity Rules evidently intended Rule 38 to apply to "genuine" class suits, apparently referring to Street's category of "true" class suits. ${ }^{396}$ Under Street's analysis, however, Balme's suit probably was a "spurious" class suit, because it concerned personal rights and liabilities rather than a fund. ${ }^{397}$ If so, then Rule 38 should not have applied to Balme's suit, and Aurelia Cauble's suit should not have been precluded.

The Court's evident assumption that the suits involving fraternal benefit associations concerned claims to a fund ${ }^{398}$ illuminates the fundamental problem with all of the fraternal benefit cases-these cases would have been much better conceived as receivership proceedings involving a trust fund with inadequate assets to cover claims, rather than as class suits concerning conflicting claims of rights and obligations. Conceptualized as receivership cases, all claims in these proceedings could have been resolved in a single litigation, with the associations dissolved at their conclusion. Instead, the parties and the courts, failing to grasp fully the insoluble nature of the underlying financial problems in fraternal benefit associations, allowed the as-

${ }^{394}$ Ben-Hur, 255 U.S. at 367.

395 Although the Court does not discuss the issue, it does refer to the finding of the master appointed by the district court in Balme's suit that it was "strictly a true class suit." Id. at 361 .

${ }^{396}$ See supra notes 344-47 and accompanying text (explaining that Rule 38 allows one or more persons of a class to sue or defend for the entire class in matters of common interest).

${ }^{397}$ See supra notes 328-30 and accompanying text (describing the distinction between "true" and "spurious" class suits, and stating that the subject of the "true" class suit is either a fund or property).

398 That the Court made this assumption is evidenced not only by its assumption that the case fell within Rule 38, see Ben-Hur, 255 U.S. at 366 ("Rule 38, as amended, was intended to apply to just such cases."), but also by its reliance on Stewart $v$. Dunham, the creditor's bill case, see id. at 365 (citing Stewart v. Dunham, 115 U.S. 61, 64 (1885)). 
sociations to reorganize and continue. This only postponed the inevitable day of reckoning and virtually guaranteed that the same issues would be litigated time and again. To forestall this consequence, the courts devised doctrines of privity and representation that allowed the decrees to bind later complainants. These doctrines, we have seen, were ill-suited to the realities of fraternal benefit associations. They were even less suited to class suits more generally, to which the broad language of Ben-Hur seemed to apply.

\section{B. Federal Rule 23}

When Federal Rule 23 was adopted in 1938, the state of the law on the binding effect of class suits thus continued to be confused, despite the fact that there now were two major Supreme Court precedents-Smith $v$. Swormstedi $t^{399}$ and Supreme Tribe of Ben-Hur v. Cauble ${ }^{400}$-confidently stating that a class suit would be binding on absentees. The drafters of Rule 23, chief among them James William Moore, continued the tradition established by these cases and by earlier commentators-they asserted that class suits would bind absentees, but ignored or explained away the difficulties and qualifications this proposition entailed and the disarray among the precedents. $^{401}$

The tripartite classification scheme adopted in Rule 23 was based on Moore's position that differences in the "jural relationships" among class members required different treatment and entailed different consequences so far as res judicata is concerned. ${ }^{402}$ As promulgated in 1938, Rule 23(a) permitted class suits:

[W] hen the character of the right sought to be enforced for or against the class is

39957 U.S. 288, 16 How. at 307 (1853).

400255 U.S. 356 (1921).

401 See Moore \& Cohn, Federal Class Actions, supra note 126, at 307, 314-16 (discussing Swormstedt and Ben-Hur in the context of "true" class suits and noting the importance of protecting rights of absentee parties through the representative of the class); James Wm. Moore \& Marcus Cohn, Federal Class Actions-Jurisdiction and Effect of Judgment, 32 ILL. L. REv. 555, 558-61 (1938) [hereinafter Moore \& Cohn, Jurisdiction and Effect] (noting that the decrees in suits described as "true class suits" would bind absentees). These two articles set forth the basic rationale underlying Federal Rule 23 as proposed and adopted. See also 2 MOORE'S FEDERAL PRACTICE, supra note 343, $\$ \S 23.04,23.07$, at 2235-45, 2286-89 (discussing the three types of class suits and stating that absentees are bound by judgment in situations classified as "true class suits").

402 See Moore \& Cohn, Federal Class Actions, supra note 126, at 314 (explaining that the classification system is "advisable" because "jural relationships" among class members, "jurisdictional requisites and the effect of judgment" differ according to the type of class suit). 
(1) joint, or common, or secondary in the sense that the owner of a primary right refuses to enforce that right and a member of the class thereby becomes entitled to enforce it;

(2) several, and the object of the action is the adjudication of claims which do or may affect specific property involved in the action; or

(3) several, and there is a common question of law or fact affecting the several rights and a common relief is sought. ${ }^{40}$

These categories of actions were labeled, respectively, "true," "hybrid," and "spurious" class suits. ${ }^{404}$

Although Rule 23 itself did not discuss res judicata, ${ }^{405}$ Moore argued that the binding effect of a class suit should depend on the category into which a suit was subsumed. With "true" and "hybrid" class suits, he stated that absentee class members were bound, although in the latter instance only as to the specific fund or property involved in the action. ${ }^{406}$ Both of these categories consisted of cases that, but for the class suit device, would require joinder of absentees as necessary parties. With "spurious" class suits, absentees were not bound, although they could elect to take advantage of a judgment favorable to the class by intervening in the action, even after judgment. ${ }^{407}$ Properly speaking, a "spurious" class suit, then, was not really a class suit at all; as Moore noted, it was really no more than a permissive joinder device. ${ }^{408}$ Most federal courts adopted Moore's statements on res

${ }^{403}$ RULE OF CIVIL PROCEDURE FOR THE DISTRICT COURTS OF THE UNITED STATES, 23(a) reprinted in 308 U.S. 689 (1939).

${ }_{404}$ See Moore \& Cohn, Federal Class Actions, supra note 126, at 314-21 (detailing the characteristics of true, hybrid, and spurious class suits, and providing cases that exemplify each type of class suit); see also 2 MOORE'S FEDERAL PRACTICE, supra note $343, \S 23.04$, at 2235-45 (describing the three types of class suits).

${ }^{405}$ In fact, the Advisory Committee explicitly rejected Moore's proposal that the Rule specify the res judicata consequences of the three categories. The Committee considered the question to be one of substance, not procedure, and thus beyond its authority. See 2 MOORE'S FEDERAL PRACTICE, supra note 343, $\$ 23.07$, at 2283 (stating that "[a]lthough it was proposed to the Committee that rules governing the effect of a class suit judgment should be incorporated in Rule 23, the proposal was rejected" (footnote omitted)).

${ }^{406}$ See id. $\$ 23.07$, at $2294-95$ (stating that the judgment rendered in true and hybrid class actions is "conclusive upon the class" and that such a judgment only reaches the specific property involved in hybrid actions).

${ }^{407}$ See Moore \& Cohn, Jurisdiction and Effect, supra note 401, at 561-62 (stating that the decree in spurious class actions does not bind absentee class members and that absentees have the option to intervene in the action and thereby "be bound by ... res judicata"); see also 2 MOORE'S FEDERAL PRACTICE, supra note 343, $\$ 23.07$, at 2291 (stating that the decree in spurious class suits will "bind only those actually before the court").

${ }^{408}$ See 2 MOORE'S FEDERAL PRACTICE, supra note 343, $\S 23.04$, at 2292 (stating that "[a] person who ... may be said to be a member of a class on whose behalf or against whom a spurious class suit is pending, may either ignore the action or intervene and become a party of record"). 
judicata as authoritative, ${ }^{409}$ but a minority of courts, and most commentators, rejected them. ${ }^{410}$

Moore created his classification system by combining Story's classification of cases ${ }^{411}$ with Street's comments ${ }^{42}$ on the binding effect of class suit decrees, ${ }^{413}$ particularly Street's categorization of "genuine" or "true" versus other class suits. Though it adopted Street's terminology of "true" and "spurious" class suits, Moore's scheme differed greatly from Street's analysis, particularly as to res judicata. Class suits concerning several rights to funds or to property (e.g., most of the creditors' bill cases) were "true" class suits to Street but became "hybrid" suits in Moore's hands, although

${ }^{409}$ See, e.g., Nagler v. Admiral Corp., 248 F.2d 319, 327 (2d Cir. 1957) (defining a "spurious" class suit as "little more than an invitation to non-parties closely interested to intervene"); All Am. Airways v. Elderd, 209 F.2d 247, 248 (2d Cir. 1954) (acknowledging that while precedent set by a court in a "spurious" suit may affect later litigation by parties who chose not to join the class, it is not res judicata as to them); Pentland v. Dravo Corp., 152 F.2d 851,852 (3d Cir. 1945) (adopting Moore's definition of a "true" class action); see also Developments in the Law-Multiparty Litigation in the Federal Courts, 71 HARV. L. REv. 874, 930 (1958) (stating that "[t]here has been an almost complete acceptance by the courts of Moore's labels and of the binding effect which he attributes to each classification" (footnotes omitted)).

${ }^{410}$ See, e.g., Rank v. (Krug) United States, 142 F. Supp. 1, 154-55 n.93 (S.D. Cal. 1956) (stating that the true test of whether res judicata applies to absent parties would be whether or not they were adequately represented in court), rev'd on other grounds, 293 F.2d 340 (1961); see also CHAFEE, supra note 313, at 250-58 (expressing doubt regarding the helpfulness of Moore's classification system for addressing the problem of when class judgments should have a binding effect); Harry Kalven, Jr. \& Maurice Rosenfield, The Contemporary Function of the Class Suit, 8 U. CHI. L. REV. 684, 710-14 (1941) (arguing that there does not always have to be a "necessary connection between the class suit and res judicata").

In addition, a number of states rejected Moore's analysis in drafting or administering their own class suit rules. See Adolf Homburger, State Class Actions and the Federal Rule, 71 COLUM. L. REV. 609, $631 \mathrm{n} .133$ (1971) (listing states that have adopted class action provisions similar to the 1966 revision of Federal Rule of Civil Procedure 23, which does not follow Moore's classification system); Jack B. Weinstein, Revision of Procedure: Some Problems in Class Actions, 9 BUFF. L. REV. 433, 456-57 (1960) (explaining that Maine rejected Moore's classification of "spurious" class suits as a third type of class suit when it adopted the Federal Rules).

The Federal Rules Advisory Committee also rejected Moore's analysis when it revised Rule 23 in 1966. See FED. R. CIV. P. 23 advisory committee's note, reprinted in 39 F.R.D. 69, 106 (1966) (discarding the former rule's three-part classification system of class suits, and maintaining a distinction only between class and nonclass suits); see also Benjamin Kaplan, Continuing Work of the Civil Committee: 1966 Amendments of the Federal Rules of Civil Procedure (I), 81 HARV. L. REV. 356, 386-94 (1967) (discussing the process by which Rule 23 was revised in 1966).

411 See supra Section II.A (detailing Story's classification of class suits).

412 See supra notes 326-43 and accompanying text (noting Street's differentiation between "true" class suits and "spurious" class suits).

${ }^{413}$ See Moore \& Cohn, Federal Class Actions, supra note 126, at 310-11 n.25 (discussing the evolution of Moore's classification scheme in Rule 23 from both Story's tripartite classification and Street's bipartite classification of class suits). 
both agreed that the decree in such suits would bind absentees. ${ }^{414}$ A greater difference emerged in their respective treatments of "spurious" class suits. To Street, all class suits other than those concerning funds or property were "spurious" and thus not binding on absentees. Moore, by contrast, created a new category of "true" class suits that included many of the cases consigned by Street to the "spurious" category. Primary among these were the association cases, such as Smith $v$. Swormstedt, ${ }^{415}$ in which a preexisting relationship so connected the class members that joinder of absentees otherwise would be required under the Necessary Parties Rule. ${ }^{416}$

Moore's creation of a separate category that included association cases harked back to Story, but Story had not specified the res judicata effects of his categories. The Supreme Tribe of Ben-Hur v. Cauble ${ }^{417}$ and the other fraternal benefit cases had been decided in the interim between Street's treatise in 1909 and Moore's work in the 1930s. This sequence may explain Moore's revival of a category of "true" class suits and his endeavor to give binding effect to cases falling within it. In fact, along with Swormstedt, Ben-Hur is the major modern example of what Moore cited as a "true" class suit. ${ }^{418}$ Although the Court in Ben-Hur implied that it was dealing with a dispute over a fund, that decision also emphasized the associational ties between the class members, and, as noted earlier, these ties were the only logical basis for treating the suit as a class suit. ${ }^{419}$ Moore clearly viewed Ben-Hur in this light. Moore's typology also had the advantage of accommodating the Court's dictum in Swormstedt, something Street's analysis was unable to do. ${ }^{420}$

Moore's categories nonetheless failed to make more sense of the precedents than had previous commentators. There were, as we have seen, a number of cases involving either funds or preexisting relationships in which courts had refused to bind absentees, and there were other cases that Moore

${ }^{414}$ See 2 MOORE'S FEDERAL PRACTICE, supra note 343, $\$ \$ 23.04,23.07$, at 2239, 2293 (stating that hybrid class suits are those in which "the rights of the members of the class are ... several" and that "[i]nsofar as the proceedings operate in rem they are conclusive").

41557 U.S. 288, 16 How. 307 (1853).

416 See 2 MOORE'S FEDERAL PRACTICE, supra note 343, §23.04, at 2239 (defining Swormstedt as a "true" class suit in which "common rights" were enforced).

417255 U.S. 356 (1921)

${ }^{418}$ See 2 MOORE'S FEDERAL PRACTICE, supra note 343, § 23.04, at 2239 (citing Ben-Hur as an example of the proper enforcement of common rights).

${ }^{419}$ See 255 U.S. at 363-64.

${ }^{420}$ See supra text accompanying notes 338-43 (noting that Street's analysis excludes preclusion for "association" cases, cases which the Swormstedt Court had concluded had the strongest basis for binding absent members). 
would have termed "spurious" in which preclusion had been applied. ${ }^{421}$ Further, although Moore categorized the Ben-Hur case as a "true" class suit, the fact that it probably did not involve a necessary parties problem, but rather implicated rights that could be termed "several," placed it in the "spurious" category.

This discussion illustrates a more fundamental problem with Moore's analysis. Moore assumed that the explanation for the differences as to when courts would find an earlier decree binding lay with the type of jural relationships involved, rather than with differing judicial attitudes toward the propriety of binding absent class members. What was needed was a persuasive rationale for determining when class suit decrees should bind absentees, not yet another attempt to make sense of the precedents. The failure of Moore's scheme to provide such a rationale quickly became evident as courts encountered great difficulty in applying the categories (e.g., when was a right "common" versus "several"?) and, especially, in determining when to bind absentees. ${ }^{423}$

${ }^{421}$ See CHAFEE, supra note 313, at 253-54 (discussing several cases, including Ben-Hur, which the author would have considered "spurious" under Moore's test, but in which the respective courts bound the absentees).

${ }^{422}$ See supra notes $295-96$ and accompanying text; see also CHAFEE, supra note 313 , at 254-56 (arguing that every member of the class in Ben-Hur had an independent right in his own policy).

${ }^{423}$ See CHAFEE, supra note 313 , at 249 (pointing out that "[i]t is not uncommon, when a case goes through several courts, for one court to call it spurious and another hybrid"). The difficulties of Moore's tripartite classification have often been identified. See, e.g., Shipley v. Pittsburgh \& L.E.R. Co., 70 F. Supp. 870, 874 (W.D. Pa. 1947) (stating that "[t]here has been considerable trouble and difficulty experienced by the courts in determining under a given set of facts whether an action filed by a group of plaintiffs is a true class suit, a hybrid class suit or a spurious class suit"); William Weiner \& Delphine Szyndrowski, The Class Action, From the English Bill of Peace to Federal Rule of Civil Procedure 23: Is There a Common Thread?, 8 WHITIER L. REV. 935, 980-85 (1987) (discussing why Moore's classifications of class suits were inadequate in helping courts determine whether certain claims should be treated as a class action under Rule 23 of the Federal Rules of Civil Procedure); Note, Federal Class Actions: A Suggested Revision of Rule 23, 46 COLUM. L. REV. 818, 822-33 (1946) ("The task of pigeonholing operative facts into one of the three categories as of "true," "hybrid,' or 'spurious' has baffled both courts and commentators." (citations omitted)). Confusion reached dizzying proportions in the Deckert litigation in which the case wound its way through the courts and was repeatedly reclassified as either a spurious or hybrid class suit. See Deckert v. Independence Shares Corp., 27 F. Supp. 763 (E.D. Pa. 1939) (holding, in part, that the suit was a spurious class suit and could be maintained even if the individuals seek to recover separate judgments), rev'd on other grounds, 108 F.2d 51, 55 (3d Cir. 1939), rev'd, 311 U.S. 282 (1940), on remand, 39 F. Supp. 592, 595-96 (E.D. Pa. 1941) (holding that the suit is a hybrid class suit because the plaintiff's interests are several and the action centers around a fund), rev'd sub nom. Pennsylvania Co. for Ins. on Lives \& Granting Annuities v. Deckert, 123 F.2d 979, 984 (3d Cir. 1941) (holding that the suit can only be maintained as a spurious class suit because the individual plaintiffs did not possess any right to common prop- 
The formalistic nature of Moore's categories glossed over many of the most difficult issues involving res judicata in class suits, just as the Supreme Court had done in its leading cases-problems such as intragroup conflicts of interest, adequacy of representation, ${ }^{424}$ and notice to absentees. Despite the seeming clarity of Rule 23 and the Supreme Court's pronouncements, these problems continued to haunt the conceptualization and adjudication of class suits.

\section{Hansberry v. Lee}

In Hansberry v. Lee, ${ }^{425}$ the Supreme Court used the Due Process Clause of the Fourteenth Amendment to overturn an Illinois state court's finding that a previous decree bound a class member who was not a party to the suit. ${ }^{426}$ The Court thus was not called upon to apply the recently adopted Federal Rule 23. Indeed, there was no explicit discussion of the recently adopted Rule 23 in the Hansberry opinion. By finally confronting some of the problems that had long lain submerged, however, the Court's analysis implicitly took issue with Moore's position that the categorization of a class suit in terms of "jural relations" would determine its conclusive effect. It also implicitly took issue with its own decision in Supreme Tribe of BenHur v. Cauble.

The facts underlying the Hansberry litigation concerned a restrictive covenant, allegedly entered into by several hundred white property owners, that prohibited blacks from occupying property in their Chicago neighborhood. The restrictive covenant was to take effect only if signed by the owners of at least $95 \%$ of the subdivision's frontage. In 1934, one of the signers of the covenant, Olive Burke, initiated an action in Illinois state court in behalf of herself and the other property owners to enjoin an asserted violation of the covenant. ${ }^{427}$ The defendant, declining to provide a defense, stipulated

erty). This progression is a clear example of how the courts were unable to determine the true nature of class suits.

${ }^{424}$ Although Moore did discuss adequacy of representation, see Moore \& Cohn, Federal Class Actions, supra note 126 , at $312-13$, he did so only cursorily and considered it relevant only to the threshold question of certification; he did not discuss it in connection with the res judicata issue.

${ }^{425} 311$ U.S. 32 (1940). The facts and previous history of the litigation are summarized in the Supreme Court's opinion, 311 U.S. at 37-40. For an interesting account of the background of Hansberry v. Lee, see Allen R. Kamp, The History Behind Hansberry v. Lee, 20 U.C. DAVIS L. REV. 481 (1987).

${ }^{426}$ See Hansberry, 311 U.S. at 45 (holding that the class representation was grossly short of satisfying the requirements of due process under the Fourteenth Amendment).

${ }^{427}$ See Burke v. Kleiman, 277 Ill. App. 519, 521 (Ill. App. Ct. 1934) (describing the facts surrounding the litigation). 
that owners of $95 \%$ of the frontage had indeed signed the covenant. The court issued the requested injunction.

Five years later, Anna Lee and several other neighborhood residents, also parties to the covenant, filed a class suit to enjoin the purchase of property in the subdivision by the Hansberrys, who were black. ${ }^{428}$ This time, however, the defendants did assert a defense, arguing that the required $95 \%$ had in fact never signed the covenant. The state trial judge agreed with the Hansberrys in his findings of fact, concluding that the previous suit had been a collusive one. Nevertheless, the trial judge sustained the covenant on the ground that the previous suit was a class suit, and that it thus was binding on all property owners in the subdivision and their successors. The Supreme Court of Illinois affirmed the trial court's conclusion, although it believed that the stipulation in the earlier suit, while untrue, was not collusive. ${ }^{429}$

The United States Supreme Court reversed. The Court began its analysis by noting that, "to an extent not precisely defined by judicial opinion," class suit judgments were an exception to the general rule that a person could not be bound by a personal judgment unless he was an actual party to the case. ${ }^{430}$ The Court's qualification seemed to express new-found reservations about the sweeping declarations made in earlier cases and was something of an acknowledgement of the peculiar nature of the cases that had announced those declarations. Indeed, aside from Smith v. Swormstedt, ${ }^{431}$ the only cases cited by the Hansberry Court at that point in its opinion were the fraternal benefit cases, including Supreme Tribe of BenHur v. Cauble, ${ }^{432}$ Supreme Council of the Royal Arcanum v. Green, ${ }^{433}$ and Hartford Life Insurance Co. v. Ibs. ${ }^{434}$

The Court next stated that the question of joinder-when a class suit would be permitted by excusing the joinder of otherwise necessary partieswas distinct from the question of res judicata. ${ }^{435}$ This statement was the

${ }^{428}$ See Lee v. Hansberry, 24 N.E.2d 37, 40 (Ill. 1939) (affirming the unreported opinion of the trial court that found the covenant binding on the other residents), rev'd, 311 U.S. 32 (1940).

${ }^{429}$ See id. at 39-40 (concluding that there was no evidence of fraud or collusion in Burke and that the suit was brought in good faith).

${ }^{430}$ Hansberry, 311 U.S. at 41.

${ }^{431}$ See id. (citing Smith v. Swormstedt, 57 U.S. 288, 16 How. 307 (1853)).

432255 U.S. 356 (1921), cited in Hansberry, 311 U.S. at 41.

433237 U.S. 531 (1915), ciled in Hansberry, 311 U.S. at 41.

434237 U.S. 662 (1915), cited in Hansberry, 311 U.S. at 41.

435 See Hansberry, 311 U.S. at 42 ("It is evident that the considerations which may induce a court thus to proceed ... may differ from those which must be taken into account in determining whether the absent parties are bound by the decree....'”). 
Court's first clear acknowledgement that these issues could be separated. More significantly, perhaps, the Court seemed implicitly to take issue with Moore's attempt to tie the res judicata consequences of class suits to their categorization. First, Moore's reading of Rule 23 gave conclusive effect to all class suits that responded to the issue of necessary parties, denying conclusive effect only to "spurious" class suits, which, Moore said, involved only the issue of permissive joinder. ${ }^{436}$ The Court, by contrast, implied that preclusion could be denied even where the class suit was of a type designed to excuse joinder of otherwise necessary parties. Conversely, the Hansberry decision also suggested that preclusion could be applied to a decree in a "spurious" class suit, so long as there was adequate representation. ${ }^{437}$

Second, and of more lasting importance, the Court virtually ignored Moore's method of looking to jural relationships to determine when a class suit decree would be binding. The Court instead stressed the issue of adequacy of representation by the class representative. The key passage reads:

It is one thing to say that some members of a class may represent other members in a litigation where the sole and common interest of the class in the litigation, is either to assert a common right or to challenge an asserted obligation. It is quite another to hold that all those who are free alternatively either to assert rights or to challenge them are of a single class, so that any group, merely because it is of the class so constituted, may be deemed adequately to represent any others of the class in litigating their interests in either alternative. Such a selection of representatives for purposes of litigation, whose substantial interests are not necessarily or even probably the same as those whom they are deemed to represent, does not afford that protection to absent parties which due process requires.

In Burke v. Kleiman, ${ }^{439}$ the case underlying the Hansberry litigation, Mrs. Burke, the named plaintiff, clearly did not adequately represent the interest of all of the members of the class of property owners. This was true regardless of whether the class was defined to include only current property

${ }^{436}$ See discussion supra notes $405-08$ and accompanying text (explaining how Moore came to the conclusion that absentees should not be bound when a class suit was found to be spurious).

${ }^{437}$ The Hansberry Court stated:

Nor do we find it necessary for the decision of this case to say that, when the only circumstance defining the class is that the determination of the rights of its members turns upon a single issue of fact or law, a state could not constitutionally adopt a procedure whereby some of the members of the class could stand in judgment for all, provided that ... those present are of the same class as those absent and that the litigation is so conducted as to insure the full and fair consideration of the common issue.

311 U.S. at 43.

${ }^{438} I d$. at 44-45 (citing Smith v. Swormstedt, 57 U.S. 288, 16 How. 307 (1854)).

439277 Ill. App. 519 (App. Ct. 1934). 
owners or also to include successors to current owners. If the class did not include successors, the Hansberrys' interests went unrepresented; if it did not include prior owners, the interests of the owners who sold to the Hansberrys were unrepresented. Further, the defendants in the Burke case could not be said to have represented either the Hansberrys or the prior owners. First, the named defendants were never designated as representatives of a class; and second, the obviously collusive nature of the suit belied any inference that they in fact represented the interests of those opposed to the enforcement of the covenant. ${ }^{440}$

In the passage quoted above, the Court cited Ben-Hur to support its contention that a decree would be binding on a class with a "sole and common interest" in asserting a common right or challenging a common obligation, because the commonality of interest likely would ensure adequate representation. ${ }^{441}$ As we have seen, however, there was no assurance in BenHur that the class representatives in the initial suit did indeed represent the interests or desires of all members of Class $A .^{442}$ It is quite plausible that at least some members of Class A felt their interest would be better served by the reorganization of the Tribe effected by its officers, even though it meant higher assessments to them. In our analysis of Ben-Hur, we noted that the interests of at least some members of the association likely were represented adequately by the officers of the Tribe (who, after all, prevailed). ${ }^{443}$ This did not, however, change the fact that the Court's handling of the representation issue in Ben-Hur was severely wanting. The more searching analysis by the Court in Hansberry was inconsistent with the doctrine announced so confidently in Ben-Hur. ${ }^{444}$

The Court in Hansberry announced a rationale for determining when class suits should be given preclusive effect-only upon adequate representation. It provided little guidance, however, concerning the content of that standard. In particular, it did not indicate what types of procedures were appropriate for ensuring, at the outset of litigation and during its

${ }^{440}$ See Hansberry, 311 U.S. at $45-46$ (noting that the Burke defendants were not treated by the pleadings or the judgment as representing anyone else or giving up any rights of others). The Court phrased the final point somewhat more delicately, probably because it was foreclosed from overturning the Illinois Supreme Court's finding of fact that the suit was not collusive. The Court said, "[E]ven though nominal defendants, it does not appear that their interest in defeating the contract outweighed their interest in establishing its validity." Id. at 46.

441 Id. at 44 (citing Supreme Tribe of Ben-Hur v. Cauble, 255 U.S. 356 (1921)).

${ }^{442}$ See discussion supra Section V.A. (analyzing the reasoning and facts of Ben-Hur).

${ }^{443}$ See discussion supra Section V.A. (analyzing the Ben-Hur Court's conclusion that there was adequate representation in the initial suit).

${ }^{444}$ See Keeffe et al., supra note 354, at 337-39 (concluding that Ben-Hur would probably be decided differently today because of its irreconcilability with Hansberry). 
course, that representation would be adequate. Encouraging or requiring notice to absentee class members was one obvious device, and the Court in Mullane v. Central Hanover Bank \& Trust Co. ${ }^{445}$ and Phillips Petroleum Co. v. Shutts ${ }^{446}$ later embraced this approach. But requiring notice cannot solve all of the problems. ${ }^{447}$ Adequacy of representation frequently can be determined only when absentees come forward claiming that their interests have not been represented adequately. If this is indeed the case, then it would seem impossible to guarantee prospectively the conclusive effect of a class suit judgment.

\section{CONCLUSION}

It is probably impossible to guarantee prospectively the conclusive effect of a class suit judgment. However, that is not really a serious objection to the class suit procedure, or to there being valid class suit judgments. It is impossible to "guarantee" the conclusive effect of any judgment. A litigant always remains free to say that there was no actual service of process, or that the process was invalid in some respect, or that the proceeding was invalidated by fraud, and so on. We have had wide experience with postjudgment habeas corpus challenges to the validity of proceedings in criminal cases, and no less imagination and persistence could well be displayed by civil litigants if the rules concerning civil judgments allowed much latitude. In civil litigation we have in fact had no such problems as have been encountered in criminal habeas corpus. The reason is that the rules of finality in civil proceedings have generally been much more stringent and more stringently enforced. But the binding effect of class suit judgments has been much more problematic, as we trust has been demonstrated in this analysis.

The essential problem is one that was long ago identified by Professor Chafee-the tension between the idea that every person has an individual right to a day in court before being precluded, on the one hand, and the idea, on the other hand, that some forms of adjudication should be preclusive on individuals notwithstanding that they did not personally participate in the

445339 U.S. 306, 314 (1950) ("[The] right to be heard has little reality of worth unless one is informed that the matter is pending and can choose for himself whether to appear or default, acquiesce or contest.").

${ }^{446} 472$ U.S. 797, 811-12 (1985) ("'An absentee] plaintiff must receive notice plus an opportunity to be heard and participate in the litigation, whether in person or through counsel.").

${ }^{447}$ For example, notice cannot guarantee that the attorneys for the class will represent their clients vigorously and fairly, given the inherent conflict of interests that often exists between the attomeys and the class over issues such as settlement. See, e.g., Saylor v. Lindsley, 456 F.2d 896, 900 (2d Cir. 1972) (stating that "[t]here can be no blinking at the fact that the interests of the plaintiff in a stockholder's derivative suit and of his attorney are by no means congruent"). 
adjudication. If there is to be a serious form of class suit, that tension must be resolved. It may once have been acceptable for the law to try to have it both ways: A class suit proceeding will, given certain preliminaries, purport to be binding, but the proceeding will not be given that effect when a member of the class actually challenges the judgment. But, in the modern era, that irresolution has become socially very expensive. The class suit is now invoked much more often than in the past precisely because it is a means of dealing "wholesale" justice in a world increasingly dominated by wholesale transactions.

Our study suggests that the law has indeed been irresolute for a long time on the question of the binding effect of a class suit judgment. The tendency has continued since the question has been constitutionalized under the rubric of the Due Process Clause of the Fourteenth Amendment. The Supreme Court in Hansberry and in cases such as Phillips Petroleum has said that class suits can be binding. But, with all deference, it must be observed that in cases such as Martin v. Wilks, Cooper v. Federal Bank of Richmond, and Amchem the Court has held or implied that, when push comes to shove, a specific class suit judgment is not binding on a member of the class who wants to relitigate.

We think that the class suit, and procedural variations of the class suit, have important social utility. They certainly have utility in cases involving claims to a limited fund-that is, where the amount of tenable claims against an obligor exceeds the assets available in behalf of the obligor. The tenable claims must be summed up and the invalid claims excluded, otherwise the distribution would be unjust to the claimants with valid claims. This must be accomplished within some finite time, otherwise the claims and the assets that could be used to pay them remain dormant, and to that extent, valueless. Hence, there must be a way to foreclose claimants who will not be forthcoming despite reasonable efforts to give them reasonable notice. That in turn means that there must be a procedure for preclusion against a person who did not participate. Recognition of this hard reality is the underlying rationale of modern bankruptcy procedure. It has been recognized by the Supreme Court in Mullane v. Central Hanover Bank. The issue is presented again in the Ortiz asbestos settlement case now pending before the Court. ${ }^{48}$

We think the class suit has still broader appropriate uses beyond "limited fund" situations. We would put the civil rights injunction class suit in that category, and we conjecture that most other sober legal analysts would

448 Ortiz v. Fibreboard Corp., 90 F.3d 963 (5th Cir. 1998), cert. granted, 118 S.Ct. 2339 (1998) (mem.). 
share that view. We think the "small claims" class suit also has justification, as the Supreme Court noted in Phillips Petroleum, although the justification is not as strong. And we think there is a place for the "mass tort" or "bill of peace" class suit as well, particularly the "settlement" class suit in such situations. The justification for "mass tort" class suits is simply that the legal system cannot satisfactorily handle myriad individual claims through individual litigation. Given modern commerce and distribution of products, there will continue to be mass misfortunes that beget litigation, and hence, "mass torts." There is little prospect of legislation that will displace personal injury litigation with some form of social insurance, or displace consumer litigation with more stringent administrative regulation. On the contrary, the litigation form for resolution of social disputes-proceedings under the aegis of courts-is an essential part of our culture, as de Toqueville long ago observed.

The question therefore is whether the litigation form can be adapted to the mass civil wrong. The archetype of that litigation form is the class suit. The class suit can be employed to resolve these disputes-as distinct from simply prolonging them-only if a judgment in such a proceeding can be really binding, that is, foreseeably binding when viewed ex-ante as well as occasionally binding ex-post. And a class suit judgment can be foreseeably binding only if the requirements of the Due Process Clause so permit. The task of formulating a binding class suit rule turns on a drafting process that satisfactorily defines "adequate representation." The requirements of due process are in the hands of the Supreme Court. If those requirements include a right to individually participate- the classic right to a day in courtthe class suit is impossible.

The task of specifying requirements of "adequacy" that conform to due process was laid open, but not resolved, in Hansberry v. Lee, and has not been resolved since then. We propose to discuss the problem in a subsequent article in this Review. 